O PRINCÍPIO DA PROPORCIONALIDADE

XIII ENCONTRO

DE PROFESSORES DE DIREITO PÚBLICO

FRANCISCO PEREIRA COUTINHO

CATARINA SANTOS BOTELHO

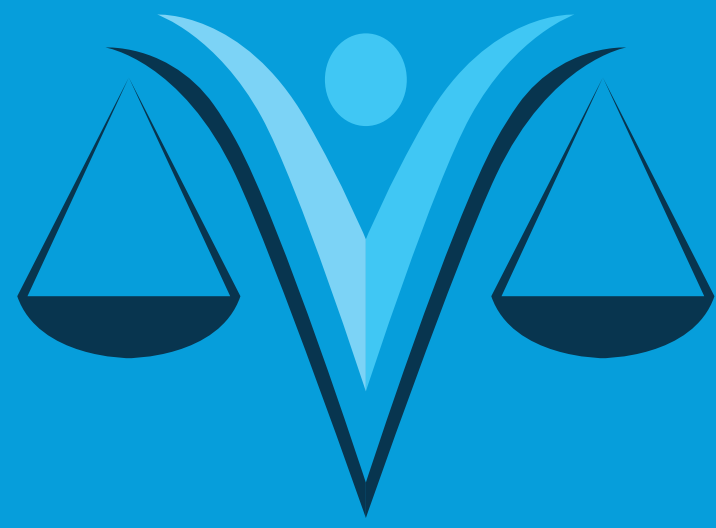

COIMBRA 



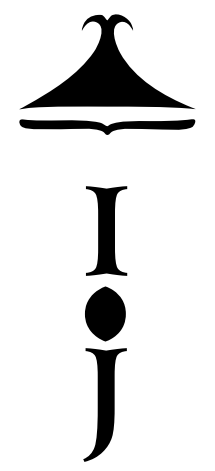


O presente livro foi realizado no âmbito das actividades da Área de Investigaçấo «Risco, Transparência e Litigiosidade», integrada no projecto «Desafios Sociais, Incerteza e Direito: Pluralidade | Vulnerabilidade | Indecidibilidade» do Instituto Jurídico da Faculdade de Direito da Universidade de Coimbra (UIDB/04643/2020).

\section{EDIC̣ÃO}

Instituto Jurídico

Faculdade de Direito da Universidade de Coimbra

\section{CONCEÇÃo GRÁFICA}

Sersilito-Empresa Gráfica, Lda.

\section{CONTACTOS}

geral@ij.uc.pt

www.uc.pt/fduc/ij

Pátio da Universidade | 3004-528 Coimbra

ISBN

978-989-9075-13-9

Depósito Legal

489004/21

www.doi.org/10.47907/clq2021_2

(C) Setembro 2021

Instituto Jurídico | Faculdade de Direito | Universidade de Coimbra 


\section{O PRINCÍPIO DA PROPORCIONALIDADE \\ XIII ENCONTRO \\ DE PROFESSORES DE DIREITO PÚBLICO}

COMISSÃO ORGANIZADORA

DULCE LOPES

FRANCISCO PEREIRA COUTINHO

CATARINA SANTOS BOTELHO 

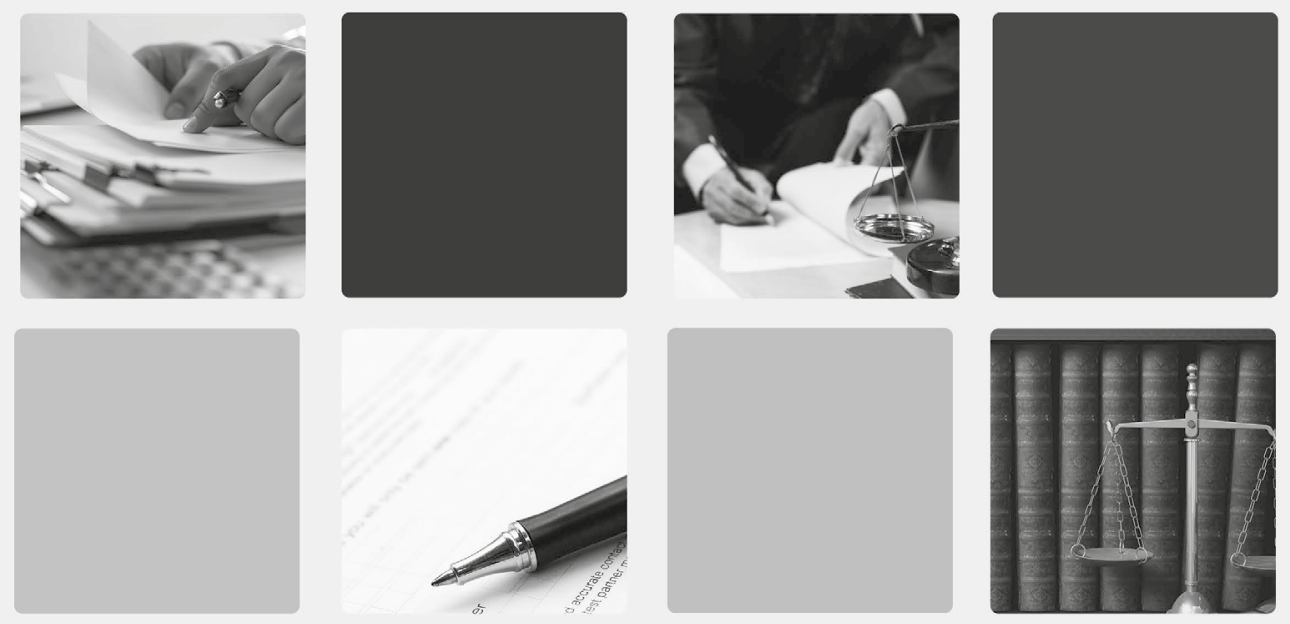

\section{O PRINCÍPIO \\ DA PROPORCIONALIDADE}

\section{0h15 SESSÃO DE ABERTURA}

(U) RUI MANUEL DE FIGUEIREDO MARCOS (Director da FDUC) JOSÉ MANUEL AROSO LINHARES (Presidente do Instituto Jurídico da UC)

\section{0h30 PROPORCIONALIDADE COMO PRINCÍPIO JURÍDICO FUNDAMENTAL}

MODERADOR:

FERNANDO ALVES CORREIA

J.C. VIEIRA DE ANDRADE

O princípio da proporcionalidade no direito administrativo VITALINO CANAS

O fundamento constitucional do princípio da proibição do excesso

ANABELA LEÃO

O princípio da proporcionalidade e os seus críticos

\section{$11 \mathrm{~h} 30 \cdot 12 \mathrm{~h} 30$ dEBATE}




\section{4 h00 JUÍZO OU JUÍZOS DE PROPORCIONALIDADE}

MODERADORA: FILIPA URBANO CALVÃO

SANDRA LOPES LUÍS

Juízos de proporcionalidade e de razoabilidade à luz do CPA de 2015 JOÃO FELIX NOGUEIRA

Juizo(s) de proporcionalidade na Jurisprudência do TJUE e TEDH ANA RAQUEL MONIZ

Juízo(s) de proporcionalidade e Justiça Constitucional

ARMANDO ROCHA

Proporcionalidade e Direito Internacional

\section{$15 \mathrm{hOO} \cdot 16 \mathrm{hOO}$ DEBATE}

Pausa para café

\section{$16 \mathrm{~h} 30 \cdot 17 \mathrm{~h} 30$ JUSTICIABILIDADE DO PRINCÍPIO DA PROPORCIONALIDADE}

MODERADOR: CARLOS BLANCO DE MORAIS

MARIANA CANOTILHO - A era da proporcionalidade no direito constitucional WLADIMIR BRITO - Processo e democracia GUSTAVO GRAMAXO ROZEIRA

Controlo jurisdicional da proporcionalidade na tributação

em aplicação da cláusula geral antiabuso

PAULA VEIGA

Proporcionalidade e TEDH: O Princípio da Proporcionalidade no

Âmbito Europeu de Protecção de Direitos Humanos

\section{$17 \mathrm{~h} 30 \cdot 18 \mathrm{~h} 30$ DEBATE}

\section{$18 \mathrm{~h} 30$ • 19hOO REUNIÃO DE ORCANIZAÇÃO DO XIV ENCONTRO DE PROFESSORES DE DIREITO PÚBLICO}

\section{0h00 JANTAR DEBATE (Quinta das Lágrimas)}

MIGUEL POIARES MADURO

Constitucionalismo sem Fronteiras e Governança para além dos Estados Apresentação a cargo de FRANCISCO PEREIRA COUTINHO 



\section{Índice}

Nota de apresentação $\ldots \ldots \ldots \ldots \ldots \ldots \ldots \ldots$

O princípio constitucional da proporcionalidade e o seu lugar na metódica constitucional. . . . . . . . . . . 11

Mariana Canotilho

www.doi.org/10.47907/clq2021_2a1

Juízo(s) de proporcionalidade e Justiça Constitucional . . . . . . 25

Ana Raquel Gonçalves Moniz www.doi.org/10.47907/clq2021_2a2

Juízos de proporcionalidade e de razoabilidade à luz dos artigos $7 .^{\circ}$ e $8 .^{\circ}$ do Código do Procedimento Administrativo. . 63

Sandra Lopes Luís

www.doi.org/10.47907/clq2021_2a3

Proporcionalidade e razoabilidade na tributação por aplicação da disposição geral antiabuso. . . . . . . . . . . 83

Gustavo Gramaxo Rozeira www.doi.org/10.47907/clq2021_2a4

Proporcionalidade e direitos humanos: TEDH e margem de apreciação . . . . . . . . . . . . . . . . . . 103

Paula Veiga www.doi.org/10.47907/clq2021_2a5

Juízos de proporcionalidade - em Direito Internacional. . . . . 111 Armando Rocha www.doi.org/10.47907/clq2021_2a6

O princípio da proporcionalidade e os seus críticos Anabela Costa Leão 



\section{Nota de apresentação}

A presente obra coletiva "Princípio da Proporcionalidade - Textos do XIII Encontro de Professores de Direito Público" compila algumas das intervenções proferidas naquele Encontro que teve lugar, no dia 24 de Janeiro de 2019, na Faculdade de Direito da Universidade de Coimbra, com o apoio desta e do Instituto Jurídico da Universidade de Coimbra.

Os textos que se publicam demonstram a centralidade do princípio da proporcionalidade no direito público, traçando os seus contornos no direito constitucional, no direito administrativo, no direito fiscal, no direito europeu e no direito internacional público. Sem esquecer, em nenhuma destas áreas, as críticas ao e os críticos daquele princípio ...

Os organizadores, oradores e público do XIII Encontro de Professores de Direito Público tiveram a sorte de poder contar com um evento presencial, repleto de encontros e de reencontros e de diálogos não mediados por um ecrã.

Pouco tempo depois, com a pandemia da COVID-19, veio perceber-se quão importante foi encetar esta reflexão conjunta sobre o princípio da proporcionalidade. Um princípio que responde aos desafios do direito em tempos de normalidade e em tempos de exceção, mostrando quão ajustável e virtuoso pode ser.

Os coordenadores

Dulce Lopes

Francisco Pereira Coutinho Catarina Santos Botelho 



\section{0 princípio constitucional da proporcionalidade e 0 seu lugar na metódica constitucional \\ - breves apontamentos a propósito da metáfora da balança}

Mariana Canotilho ${ }^{1}$

SUMÁRIO: 1. A proporcionalidade como princípio metódico e pilar essencial de uma "Constituição mínima". 2. Proporcionalidade e direitos fundamentais. 3. Dificuldades práticas; 3.1. Os elementos de ponderação; 3.2. A linguagem métrica da proporcionalidade.

\section{A proporcionalidade como princípio metódico e pilar essencial de uma "Constituição mínima".}

O tema da proporcionalidade tem ocupado uma porção significativa do debate académico em matérias jurídico-públicas e, mais especificamente, jurídico-constitucionais, nas últimas décadas. Princípio aberto e maleável, tem-se revelado operativo no quadro de uma metódica constitucional da complexidade, uma vez que permite um conjunto de exercícios racionalizadores relevantes, no quadro

1 Docente da Faculdade de Direito da Universidade de Coimbra; Juíza Conselheira do Tribunal Constitucional, desde 2019. O texto serviu de base à intervenção no XIII Encontro de Professores de Direito Público, realizado na Faculdade de Direito da Universidade de Coimbra, a 24 de janeiro de 2020. 
da ponderação jurídico-constitucional, bem como uma vantagem operativa não ignorável, a saber:

i) a mobilização e consideração de um conjunto de direitos e valores constitucionalmente relevantes, em conflito ou dissonância entre si;

ii) a possibilidade de sopesar esses elementos, atendendo à sua distinta relevância, quer do ponto de vista da axiologia e arquitetura constitucionais, quer no que respeita às especificidades do caso concreto;

iii) a facilidade da construção de consensos, evitando discussões sobre a densificação de normas constitucionais de direitos fundamentais, que forçariam uma definição mais marcada do feixe de direitos, pretensões e faculdades que cada norma consagradora de um direito subjetivo fundamental confere aos cidadãos, seus titulares.

Estas significativas vantagens de ordem prática, levaram a que o princípio da proporcionalidade ganhasse progressiva relevância, sendo, hoje, um dos parâmetros de constitucionalidade mais frequentemente mobilizados como fundamento de um juízo de desconformidade com a Constituição, como amplamente demonstra a jurisprudência constitucional portuguesa.

A proporcionalidade (entendida em sentido amplo) é, pois, considerada como princípio geral de limitação da atividade do poder público - quer no que respeita à concretização de princípios jurídicos (como a subsidiariedade), quer quanto a medidas restritivas de direitos fundamentais - assumindo uma relevância crescente no plano da jurisprudência constitucional comparada, incluindo na jurisprudência dos tribunais supranacionais, como o Tribunal de Justiça da União Europeia (TJUE) ou o Tribunal Europeu dos Direitos Humanos (TEDH). O princípio expandiu-se de maneira significativa, e a discussão em torno do seu significado, operacionalidade, 
metodologia e limites constitui, hoje, um interessante diálogo global entre academias e jurisdições².

Não deixa de ser paradoxal que o frequentíssimo recurso ao princípio da proporcionalidade como fundamento de juízos de inconstitucionalidade, quer combinado com outros princípios fundantes do Estado de direito, - como o princípio da igualdade, ou, em Portugal, o princípio da proteção da confiança -, quer associado à avaliação de uma medida afetadora de direitos fundamentais, apareça, pelo menos de forma aparente, desligado de uma profunda reflexão, e até de uma opção jurisprudencial, em torno da correspondente teoria de direitos fundamentais. Ora, a opção pela proporcionalidade representa, amiúde, uma não opção pelos direitos. Ou seja, cada vez que se opta por mobilizar este fundamento, isoladamente, ou em conjugação com outros princípios fundamentais, faz-se uma opção

2 Cfr., entre outros: C. Bernal Pulido, El principio de proporcionalidade y los derechos fundamentales, Centro de Estudios Políticos y Constitucionales, Madrid, 2005; J. Christoffersen, Fair Balance: Proportionality, Subsidiarity and Primarity in the European Convention on Human Rights, Martinus Nijhoff Publishers, 2009; A. Barak, Proportionality - Constitutional rights and their limitations, Cambridge University Press, 2010; M. KLATT (ed.), Institutionalized Reason: The Jurisprudence of Robert Alexy, OUP, 2012; L. LAZARUS, C. MaCCrudden (ed.), Reasoning Rights: Comparative Judicial Engagement, Hart Publishing, 2014; N. PETERSEN, Verhältnismäßigkeit als Rationalitätskontrolle: Eine rechtsempirische Studie verfassungsgerichtlicher Rechtsprechung zu den Freiheitsgrundrechten, Mohr Siebeck, 2015; V. JaCKSOn / M. Tushnet (ed.), Proportionality: New Frontiers, New Challenges, Cambridge University Press, 2017; F. URBINA, A Critique of Proportionality and Balancing, Cambridge University Press, 2017; A. Stone Sweet e J. MATHEWs, Proportionality Balancing and Constitutional Governance: A Comparative and Global Approach, OUP, 2019; D. GOnZÁlez CARVAllo / R. SÁnCHEZ GIL (coord.), El Test de Proporcionalidad, Convergencias y divergências, Centro de Estudios Constitucionales de la Suprema Corte de Justicia de la Nación, 2021.

Entre nós, por exemplo, J. ReIS NovaIs, Direitos Fundamentais: Trunfos contra a Maioria, Coimbra Editora, 2006; P. Machete / T. Violante, O Princípio da Proporcionalidade e da Razoabilidade na Jurisprudência Constitucional, também em relação com a Jurisprudência dos Tribunais Europeus, Relatório à XV Conferência Trilateral dos Tribunais Constitucionais de Espanha, Itália e Portugal, tribunal Constitucional, 2013; L. Nunes Vicente, O Princípio da Proporcionalidade - Uma nova abordagem em Tempos de Pluralismo, Faculdade de Direito da Universidade de Coimbra - Instituto Jurídico, 2014;V. CANAS, O Princípio da Proibição do Excesso na Conformação e no Controlo de Atos Legislativos, Almedina, 2017. 
jurídico-constitucional que escolhe a linguagem principialista da razoabilidade e da ponderação, em detrimento da linguagem, mais impositiva, dos direitos fundamentais. Por outro lado, mesmo quando a proporcionalidade é considerada enquanto parâmetro de validade de uma restrição a um direito fundamental - e, por isso, umbilicalmente associada a esse mesmo direito enquanto fundamento de um juízo de desconformidade com a Constituição - a verdade é que assim se sufraga uma determinada conceção de direitos fundamentais (em regra, de entre possíveis variações em torno da conceção alexiana de direitos prima facie) que, sendo talvez maioritária, hoje, pelo menos no quadro da jurisprudência e doutrina europeias, não é única, e é objeto de críticas que vale a pena considerar.

Mais ainda: é também paradoxal que o diálogo jurisprudencial e académico em torno da proporcionalidade pareça tão distante da discussão sobre a teoria da Constituição. O que foi e o que é, hoje, uma Constituição, para que serve, em que termos devem ser consideradas e jurisdicionalmente impostas, por um lado, as fronteiras nela traçadas à atuação dos poderes públicos e, por outro lado, as imposições de atuação a esses mesmos poderes?

A supremacia paramétrica - ainda que não em termos hierárquicos, mas simplesmente práticos - do princípio da proporcionalidade serve bem uma teoria da constituição mínima, reduzida a instrumento de governo (ou documento definidor do que R. Gargarella chamou a sala de máquinas da constituição ${ }^{3}$, referindo-se ao desenho dos órgãos de soberania e respetivas competências e relações de interdependência, ou seja, à forma de organização do poder político), conjugado com a garantia de respeito por um conjunto relativamente reduzido de princípios estruturantes (como a igualdade, a separação de poderes, ou a proporcionalidade) e por um catálogo de direitos fundamentais de densificação aberta. Na expressiva descrição de G. Almeida Ribeiro ${ }^{4}$, "a principal missão do poder constituinte, resignado à precariedade da sua força e legitimidade, é a de instituir as condições

3 Crf. R. Gargarella, La Sala, 2014.

4 G. Almeida RibeIro, O conceito pós-moderno de constituição, in Atas do XII Encontro de Professores de Direito Público - O Poder Judicial: Revisitar o passado e pensar o futuro, Escola de Direito da Universidade do Minho, 2020. 
orgânicas e procedimentais de auto-determinação coletiva. (...) Em suma, só uma constituição mínima pode traduzir, na língua própria da pós-modernidade, o projecto de vida comum do constitucionalismo". Nestes termos, a proporcionalidade surge como mecanismo racionalizador de uma ponderação operada pelos titulares do poder - maxime, pelos juízes constitucionais - entre princípios, valores e direitos de natureza constitucional, sempre, a priori, de idêntico valor e necessariamente abertos a juízos de equilíbrio e concordância prática.

A questão torna-se, porém, mais inquietante, para quem não partilhe deste constitucionalismo mínimo, e se reveja numa - de entre várias - teoria da Constituição que a conceba como mais do que isso. Do constitucionalismo dirigente ao constitucionalismo crítico, passando pelo constitucionalismo transformador ou pela häberliana conceção do direito constitucional como ciência da cultura, até ao nascente constitucionalismo do comum, são múltiplos os entendimentos da Constituição como algo mais do que - ou, pelo menos, algo distinto de - um instrumento operativo do exercício do poder político democrático. Para os que subscrevam a premissa segundo a qual uma Constituição é mais do que o conjunto das suas disposições normativas, e constitui a opção por e a consagração de um projeto político concreto, democraticamente negociado e aprovado, expressão do específico contexto cultural e histórico de um povo, com um elemento de utopia e uma clara dimensão programática, impositiva, dirigente ou qualquer outra expressão que possa preferir-se -, em determinadas matérias, a redução de boa parte das questões de constitucionalidade a um debate em torno da sua proporcionalidade é problemática. É-o porque reduz, naturalmente, a possibilidade de afirmação de opções prefiguradas pelo legislador constituinte, imunes à ponderação tanto do legislador ordinário, quanto do juiz constitucional. Por outras palavras, para quem entenda que as constituições contêm específicos cadernos de encargos para o poder político constituído, há opções legislativas cuja inconstitucionalidade deve ser reconhecida antes mesmo de se recorrer ao princípio da proporcionalidade. Isto acontecerá sempre que se prefigure que o legislador constituinte consagrou uma regra constitucional expressa, que cristaliza uma opção, a priori, de concordância prática entre potenciais valores ou direitos em conflito, 
numa determinada situação, (por exemplo, proibindo certas restrições a um direito fundamental, ou limitando-as a casos pré-definidos no texto constitucional); resumindo, quando, por via interpretativa, se entenda estarmos perante "situações em que a própria Constituição garante uma faculdade, uma garantia, uma pretensão ou uma faceta particular do direito, mas já a título definitivo, absoluto, ou seja, o legislador constituinte fez logo ali, ele mesmo, todas as ponderações que havia a fazer e decidiu-se intencionalmente pela garantia, a título definitivo, do interesse jusfundamental em questão" ". Por outro lado, se se partilhar uma visão da Constituição axiologicamente comprometida, além do reduzido núcleo de princípios estruturantes acima mencionado, torna-se indispensável discutir o quê, e em que termos, pode (ou tem que) ser ponderado, em sede de mobilização do princípio da proporcionalidade.

Neste quadro, três questões fundamentais emergem, a meu ver, como incontornável objeto de reflexão: i) a problemática da conjugação entre a ideia de proporcionalidade e os direitos fundamentais enquanto critérios operativos de decisão judicial; ii) a necessidade de definição prévia e de delimitação dos elementos admissíveis de ponderação; iii) a questão das indefinições resultantes da linguagem métrica da proporcionalidade. A elas aludiremos, brevemente, nos pontos seguintes.

\section{Proporcionalidade e direitos fundamentais}

Todos os intérpretes de normas de direitos fundamentais compreendem que, para cada direito fundamental, existe um, ou vários, interesse(s) público(s) conflituante(s). Por outras palavras, e como ensina J. Weiler ${ }^{6}$, para além do que poderíamos designar como esfera ou núcleo fundamental (que não se confunde com o núcleo essencial), a definição e densificação do significado dos direitos fundamentais

5 Cfr. J. Reis Novais, Direitos Fundamentais, 2006, pp. 51.

6 Veja-se J. H. H. WeILER, Fundamental Rights and Fundamental Boundaries: Common Standards and Conflicting Values in the Protection of Human Rights in the European Legal Space, in R. KASTORYANO (ed.), An Identity for Europe, The Relevance of Multiculturalism in EU Construction, Palgrave Macmillan, 2011. 
constitui uma opção central de cada comunidade política, que reflete escolhas fundantes dessa mesma comunidade, moldadas pela sua identidade coletiva. Os concretos catálogos de direitos fundamentais e o seu significado são, pois, parte de uma identidade social partilhada, têm inegável relevância comunitária e podem originar conflitos quando mobilizados em espaços constitucionais distintos, como sucede quando normas ou decisões nacionais são apreciadas em tribunais supranacionais, como é o caso do TEDH. Exemplificando, é devido a isto que a fronteira de concordância prática entre os direitos fundamentais à liberdade de expressão (artigo 37. da CRP), por um lado, e ao livre desenvolvimento da personalidade e ao bom nome e reputação (artigo $26 .^{\circ}$ da CRP), por outro, é entendida de modo tão distinto no nosso país e fora dele que originou dezenas de condenações do Estado português pelo TEDH. Ou seja, sabemos que a interpretação das normas de direitos fundamentais implica a definição de limites, ou fronteiras fundamentais, correspondentes a valores com eles conflituantes. Se é sempre assim, dir-se-á, então é lógico que se mobilize em (quase) todos os casos o princípio da proporcionalidade, desdobrando-se a análise de conformidade constitucional nos passos necessários à verificação dos subprincípios dogmaticamente estatuídos de necessidade, adequação e proporcionalidade em sentido estrito.

Contudo, cabe questionar se isto será verdade em qualquer situação, ou em todas as circunstâncias. É relevante para a resposta a essa pergunta, antes de mais, a conceção de cada um sobre o que significa ter um direito fundamental; isto é, como acima se referiu, é incontornável mobilizar para esta reflexão a teoria dos direitos fundamentais. Aquela mesma pergunta é colocada, por exemplo, por M. Kumm na sua análise sobre a relação entre direitos fundamentais e proporcionalidade nas teses de Alexy, e as dificuldades que se levantam a esse respeito em sede de fiscalização da constitucionalidade.

7 Ver, por exemplo, M. Kumm, Alexy's Theory of Constitutional Rights and the Problem of Judicial Review, in M. KLATT (ed.), Institutionalized Reason: The Jurisprudence of Robert Alexy, OUP, 2012. 
É certo que R. Alexy constrói, na sua mais conhecida obra ${ }^{8}$, uma teoria dos direitos fundamentais que os concebe, do ponto de vista estrutural, de forma tão ampla e dúctil que permite (re)conciliá-los com as hodiernas práticas jurisdicionais em matéria de direitos humanos e direitos fundamentais, seguidas em boa parte das democracias constitucionais (e, em particular, das democracias do espaço europeu), bem como nos tribunais supranacionais com competência em matéria de direitos fundamentais. Fá-lo, simplificando, ao atribuir aos direitos a natureza estrutural de princípios, - entendidos como verdadeiros requisitos de otimização -, o que implica uma indispensável mobilização do princípio da proporcionalidade na sua adjudicação. Contudo, a verdade é que esta compreensão dos direitos difere da tradicional conceção liberal, nas suas distintas declinações ${ }^{9}$, acerca do que significa ter um direito. Quer se conceba como um trunfo contra a maioria, que o torna imune a ponderações ou afirma a sua prioridade sobre considerações acerca do bem, coletivamente determinado, ou, antes, como uma barreira de proteção contra exigências de interesse público, a realidade é que este entendimento dos direitos corresponde ao significado dos mesmos na linguagem comum e, em grande medida, às expectativas dos cidadãos. Neste sentido, é necessário definir o significado dos direitos fundamentais concretamente consagrados em cada catálogo; na verdade, se um direito subjetivo fundamental apenas conferisse ao seu titular um interesse constitucionalmente tutelado, obrigatoriamente mobilizável na ponderação de proporcionalidade a levar a cabo pelo intérprete constitucional, a realidade é que a diferença entre direitos fundamentais e quaisquer outros interesses atendíveis não se perspetivaria como significativa. E, no entanto, não se pode dizer que assim seja, pelo menos não em todos os casos, ou em relação a todo o âmbito de proteção garantido pelo direito.

Para aqueles que perfilhem uma qualquer teoria da Constituição que vá além da constituição mínima, impor-se-á, pois, a ideia

8 R. Alexy, A Theory of Constitutional Rights, OUP, 2010.

9 Vejam-se os clássicos de R. DwORKIN, Taking Rights Seriously, Harvard University Press, 1978 e J. RaWls, Political Liberalism, Columbia Classics in Philosophy, Columbia University Press, edição expandida, 2005. 
segundo a qual, pelo menos para alguns direitos, e/ou em relação a determinadas dimensões (faculdades parcelares) de um direito, o seu reconhecimento enquanto trunfos (ou outra figura análoga, reconduzível a uma ideia de indisponibilidade) é uma decorrência "do reconhecimento da força normativa da Constituição, da necessidade de levar a Constituição a sério: por maioritários que sejam, os poderes constituídos não podem pôr em causa aquilo que a Constituição reconhece como direito fundamental"10. Enquanto fronteiras à atuação dos poderes públicos, os direitos fundamentais excluem certas possibilidades da margem de conformação do legislador constituído, nos casos em que o legislador constituinte tenha entendido colocá-las para além de quaisquer considerações de razoabilidade ou proporcionalidade. Foi o que fez, por exemplo, o legislador constituinte português quando proibiu a pena de morte (artigo $18 .^{\circ},{ }^{\circ}{ }^{\circ} 2$, da CRP) e a tortura (artigo 19..$^{\circ}$, n. ${ }^{\circ} 2$, da CRP).

Nesta medida, é indispensável encontrar, na dogmática e na metódica constitucional, um equilíbrio entre a delimitação do conteúdo indisponível (ou do conjunto de faculdades parcelares indisponíveis) de certos direitos e a ponderação, com recurso ao princípio da proporcionalidade, nos restantes casos. No quadro português, e tendo em mente que a CRP proíbe "diminuir a extensão e o alcance do conteúdo essencial dos preceitos constitucionais" (artigo 18. ${ }^{\circ}$ ), seria desejável refletir e procurar consensos crescentes em torno da amplitude desse conteúdo essencial, que deve ir além do tradicional núcleo essencial, se quisermos levar a sério a normatividade e essencialidade dos direitos fundamentais, enquanto fronteiras de um espaço de liberdade e autodeterminação, frente, antes de mais, ao Estado, mas também, e com relevância crescente, a outras entidades públicas e privadas.

Para tal, urge, desde logo, uma densificação das normas de direitos fundamentais pela sociedade aberta dos seus intérpretes, de preferência, prévia à sua aplicação pelos tribunais. Ou seja, os direitos precisam de conteúdo, sem o qual o espaço de decisão e determinação por parte do juiz se alarga, em termos potencialmente problemáticos, no que respeita à separação de poderes, numa sociedade democrática. No fundo, estamos apenas a dizer que, se os direitos fundamentais não podem ser sempre, em todos os casos, simples princípios, há que

10 J. Reis Novais, Direitos Fundamentais, 2006, pp. 36. 
fazer um esforço dogmático no sentido de perceber onde e quando é que eles assumem uma estrutura mais próxima das regras. Por exemplo, quando o legislador constituinte estatuiu o direito ao recurso, em processo penal (artigo 32. ${ }^{\circ}$, n. ${ }^{\circ} 1$, da CRP), em que casos ou circunstâncias é que esse direito sempre se imporá ao legislador, e em quais pode ser objeto de ponderação em face de outros valores constitucionalmente protegidos? O campo de maior e melhor densificação a este nível - ainda que reste bastante trabalho por fazer - é, precisamente, o da chamada constituição penal, mas não há razões fundamentais para não se trilhar caminho semelhante noutras áreas.

\section{Dificuldades práticas}

Além da relação incontornável com a teoria da Constituição e a teoria dos direitos fundamentais de que acima se deu conta, a aplicação jurisprudencial do princípio da proporcionalidade coloca dificuldades práticas, mesmo no amplo espaço aberto à ponderação. Assinalaremos duas, em particular, sentidas com maior frequência.

\subsection{Os elementos de ponderação}

A primeira destas dificuldades centra-se na delimitação dos elementos de ponderação. Se se vai "pesar" direitos e valores constitucionalmente relevantes, o que pode estar nos pratos da balança? Estão os direitos prima facie, em toda a sua amplitude e generosidade definidora? A resposta comummente aceite a esta questão é hoje afirmativa, tendo sido abandonada, de forma progressiva, a teoria dos limites imanentes. Mas o equilíbrio deve ser procurado apenas quando estejam em causa valores com assento constitucional, ou também quando se trate de interesses formalmente infraconstitucionais, com relevância no caso concreto? Cremos que não deve o juiz constitucional ultrapassar a barreira da Lei Fundamental na delimitação do perímetro de relevância de tais elementos de ponderação ${ }^{11}$, sendo, porém, evidente que também o estabelecimento dessa barreira

11 É inversa a posição de J. ReIs NOvAIS, Direitos Fundamentais, 2006, pp. 53, nota 43 . 
está sujeito a debate interpretativo e fundamentação. A verdade é que, pelo menos no caso português, a Constituição expressamente refere a necessidade de "salvaguardar outros direitos ou interesses constitucionalmente protegidos" (artigo 18. ${ }^{\circ}$, n. $^{\circ}$ 2). Nestes termos, deverá emitir-se um juízo de inconstitucionalidade sempre que se entenda que a norma questionada visa tutelar, restringindo um direito, ou com compressão assinalável de um princípio fundamental, um bem sem verdadeiro abrigo na Constituição. No fundo, levando a sério a sua força normativa e o seu específico projeto constitucional, admitir-se-á que há casos em que normas/medidas legislativas que parecem razoáveis, em face de uma avaliação global do caso concreto, não podem ser tidas como proporcionais, por não poderem levar-se em consideração os bens e interesses de natureza infraconstitucional que o legislador visava proteger.

Por outro lado, cabe notar a importância da justificação, fundamentação, e até da eventual prova de existência e/ou delimitação do direito, princípio ou valor constitucional que serve de elemento de ponderação. No fundo, a questão é esta: basta ao legislador ordinário invocar um qualquer direito ou valor com assento na CRP, para que o juiz deva considerar comprovada a sua existência, e os específicos contornos segundo os quais é descrito? Qual é o grau de escrutínio a que deve ser submetida a justificação apresentada pelo legislador, por exemplo, para uma medida restritiva de direitos fundamentais? Como se comprova a necessidade de tal medida, para que se possa considerar respeitado o primeiro subprincípio do juízo de proporcionalidade? Bastará a sua verosimilhança? Ou será exigível prova, pelo menos quando se funde em alegações quantitativa ou qualitativamente comprováveis? A verdade é que há, com alguma frequência, na fundamentação das medidas legislativas, afirmações de facto empiricamente verificáveis, como verdadeiras ou falsas. Seria, pois, fácil admitir que o juízo de inconstitucionalidade fundado na proporcionalidade não devesse evitar, no mínimo, essa comprovação; contudo, pode não ser trivial afirmá-la, até mesmo em face dos mecanismos processuais legislativamente definidos. Assim, na resposta a estas questões conflui uma análise e eventual reconstrução da arquitetura sistémica, no que tange à fiscalização da constitucionalidade, e aos problemas de separação e interdependência de poderes. 
Além das já referidas, outra das dificuldades da aplicação prática da proporcionalidade é de natureza metódica e consiste em definir se se adota um caminho metodológico de prioridade aos direitos (isto é, partindo do direito limitado de maneira alegadamente inconstitucional, e avaliando a medida conflituante à luz da dogmática da proporcionalidade aplicada às normas restritivas) ou, por outro lado, um caminho de otimização dos direitos ou bens constitucionalmente relevantes em oposição. As operações metodológicas a levar a cabo não conduzirão, pelo menos não necessariamente, a um resultado idêntico. Poderá também haver diferenças importantes consoante esteja em causa um interesse público ou outro direito subjetivo fundamental, diferenças essas assentes na própria natureza e estrutura dos direitos fundamentais. No fundo, questiona-se se haverá algum tipo de prioridade a conferir, na mobilização do princípio da proporcionalidade enquanto parâmetro de validade, ao direito cuja validade é invocada, e em que termos a mesma deveria operar. É uma questão discutidíssima entre a doutrina especializada na matéria ${ }^{12}$, e que nos conduz de volta à afirmação da necessidade de conjugar, em sede de interpretação constitucional, a metódica da proporcionalidade com uma teoria bem definida dos direitos fundamentais. Sucede que as respostas variarão em função da tese que se sufrague a esse respeito, e que será fundamental para encontrar soluções para casos difíceis, que se multiplicam em matérias como a liberdade de expressão e a liberdade religiosa (veja-se, por exemplo, a saga judicial sobre o uso do véu islâmico no local de trabalho, constituída, desde logo, pelas decisões do TJUE nos casos Achbita $^{13}$ e Bougnaoui ${ }^{14}$, e pela decisão do TEDH no caso Eweida and Others v. The United Kingdom ${ }^{15}$ ).

12 Ver, por exemplo, a discussão travada em vários dos artigos constantes de D. González Carvallo / R. SÁnchez Gil (coord.), El Test, 2021.

13 V. Acórdão do TJUE, Samira Achbita c. G4S Secure Solutions, processo C-157/15, de 14 de março de 2017.

14 V. Acórdão do TJUE, Asma Bongnaoui c. Micropole SA, processo C-188/15, de 14 de março de 2017.

15 V. Acórdão do TEDH, Eweida and Others v. The United Kingdom, de 27 de maio de 2013. 


\section{2. $A$ linguagem métrica da proporcionalidade}

Por último, cabe ainda lembrar que a metódica da proporcionalidade nos remete para juízos fundamentados com recurso a uma linguagem métrica, que não está isenta de crítica ou problematização.

Em primeiro lugar, há que considerar que, para muitos dos que sufragam uma teoria da Constituição além do mínimo, é relevante a constatação de que o específico projeto constitucional da CRP contém um importante catálogo de direitos económicos, sociais e culturais. Ora, nestes termos, há que lembrar que os direitos fundamentais podem - e devem - ser chamados aos juízos de ponderação, sem distinções de ordem hierárquica ou metodológica. Todos os direitos pesam, nas circunstâncias em que sejam mobilizáveis para a resolução de um caso concreto, pelo menos na sua dimensão negativa, de resistência à atuação do legislador, e esta premissa não deve ser afastada com fundamento na ausência de consenso sobre a densificação do sentido e alcance da dimensão positiva do direito. Ou seja, se levarmos a sério a metáfora da balança, não podemos deixar de considerar um direito de natureza social, como contrapeso aos direitos ou valores invocados pelo legislador para justificar uma norma cuja conformidade constitucional se vê questionada. Numa palavra, não é porque inexiste consenso sobre a dimensão prestacional de um direito como a habitação que o mesmo deve ser ignorado na avaliação da proporcionalidade de medidas que, por alguma razão, ainda que plenamente atendível, privam os titulares desse direito da habitação que já têm. Contudo, este tipo de direitos é frequentemente avaliado como tendo menos peso do que os seus contrapólos valorativos, ou até como sendo irrelevante para a ponderação, com fundamento na sua estrutura, natureza ou regime jurídico. Esta visão das coisas é problemática, pelo menos no quadro de certas teorias da Constituição e até mesmo de algumas teorias de direitos fundamentais, levantando questões metodológicas sobre proporcionalidade, respeitantes, essencialmente, à avaliação do cumprimento do subprincípio da necessidade.

Por outro lado, pode afirmar-se que a linguagem métrica é inerente às disposições de direitos fundamentais (que nos remetem para a ideia de standards, de maior e menor proteção, da menção a níveis 
elevados ou aos níveis mais elevados de tutela jusfundamental), pelo que não se afigura, a priori, desadequada para a fundamentação de juízos de ponderação e de conformidade constitucional. Contudo, é indispensável exigir a maior clareza possível quanto às operações metodológicas e aos fundamentos valorativos e axiológicos que presidem a tais juízos de ponderação. Não são desprovidas de sentido críticas como a de $\mathrm{M}$. Tushnet ${ }^{16}$, quando, analisando casos célebres da jurisprudência alemã nos quais se recorre ao princípio da proporcionalidade, afirma que muitas das fundamentações aduzidas para justificar um juízo de inconstitucionalidade seriam facilmente reversíveis, do ponto de vista argumentativo, podendo sustentar um juízo de sentido inverso. A verdade é que a opção por uma ponderação fundada na proporcionalidade deve ser, ela própria, racionalizada em termos justificativos, em particular nos casos em que se escolhe o afastamento de uma linguagem dos direitos (em termos liberais), ainda logicamente invocável, preferindo-se o controlo de constitucionalidade menos denso permitido pela linguagem dos princípios. No entanto, é sabido que o problema não se coloca desta forma numa perspetiva puramente alexiana, o que nos remete, uma vez mais, para a perplexidade de uma aplicação do princípio da proporcionalidade, sem claras escolhas em sede de teoria dos direitos fundamentais.

Por fim, é inegável que a linguagem métrica se revela particularmente difícil em contextos de pluralismo (cultural, político) ou complexidade extrema, nos quais os chamados critérios de evidência (muitas vezes invocados pela jurisprudência constitucional) se revelam, amiúde, desadequados. Tendo em conta a atual realidade pós-pandémica, e os ensinamentos que dela podemos já retirar, esta dificuldade tenderá a crescer, quer no que respeita ao número de casos em que se levanta, quer quanto à magnitude com que se impõe ao julgador.

16 Cfr. M. Tushnet, Making Easy Cases Harder, in V. Jackson / M. Tushnet (ed.), Proportionality: New Frontiers, New Challenges, Cambridge University Press, 2017. 


\title{
Juízo(s) de Proporcionalidade e Justiça Constitucional*
}

\author{
Ana Raquel Gonçalves Moniz**
}

SUMÁRIO: 1. Introdução; 2. Os juízos de proporcionalidade desenvolvidos pela Justiça Constitucional; 2.1. Juízo(s) de proporcionalidade e funções do princípio: reflexão cruzada; 2.2. Tipologia(s) dos juízos; 2.2.1. Questão prévia: testes, dimensões normativas ou juízos?; 2.2.2. Em especial, o(s) juízo(s) de proporcionalidade na ótica do Tribunal Constitucional português; 3. Limites ao princípio da proporcionalidade: justiça e separação de poderes; 4. Princípio da proporcionalidade e Justiça Constitucional global: os novos horizontes da Justiça Constitucional; 5. Reflexões finais.

\section{Introdução}

Independentemente da densificação conferida ao princípio da proporcionalidade ou princípio da proibição do excesso ${ }^{1}$, este último

* O presente texto teve na sua origem a conferência proferida pela Autora no XIII Encontro de Professores de Direito Público, que decorreu na Faculdade de Direito da Universidade de Coimbra, no dia 24 de janeiro de 2020.

** Professora da Faculdade de Direito da Universidade de Coimbra.

1 A doutrina nacional não é, todavia, unânime quanto à equivalência entre ambas as expressões. Preferindo a designação de princípio da proibição do excesso, na senda da proposta de LERCHE (Übermaß und Verfassungsrecht: Zur Bindung des Gesetzgebers and die Grundsätze der Verhältnismäßigkeit und der Erforderlichkeit, Carl Heymanns Verlag, Köln, 1961), v. ReIS NovAIS, Princípios Estruturantes do Estado de Direito, Almedina, Coimbra, 2019, p. 103. Considerando, porém, mais adequada a referência ao princípio da proporcionalidade, $v$. VITALINO CANAS, 
corresponde a uma exigência axiológica da ideia de um Estado de direito ${ }^{2}$, vinculando, enquanto tal, toda a ação jurídico-pública (sem distinção da função estadual em causa) ${ }^{3}$. As suas refrações não se circunscrevem, além disso, ao Direito Constitucional e Direito Administrativo nacionais, mas espraiam-se pelo Direito Público comparado, atingindo o Direito Internacional ${ }^{4}$ ou o Direito da União Europeia, assim como ramos jurídico-dogmáticos mais recentes, como o Direito do Investimento ${ }^{5}$.

Proporcionalidade (Princípio da), in Dicionário Jurídico da Administração Pública,VI, s.n., Lisboa, 1994, p. 595; cf., porém, a posição adotada em Vitalino CANAS, O Princípio da Proibição do Excesso na Conformação e no Controlo de Atos Legislativos, Almedina, Coimbra, 2017, pp. 45 ss.

2 Assim, entre nós, Gomes Canotilho (Direito Constitucional e Teoria da Constituição, 7. ${ }^{a}$ ed., Almedina, Coimbra, 2003, pp. 266 ss.) integra-o no elenco dos subprincípios concretizadores do princípio do Estado de direito; MARIA LÚCIA Amaral (A Forma da República: Uma Introdução ao Estudo do Direito Constitucional, Coimbra Editora, Coimbra, 2005, p. 187) apresenta, como sedes materice do princípio, o artigo 2. ${ }^{\circ}$ da CRP; PAulo OTERo (Direito Constitucional Português, I - Identidade Constitucional, Almedina, Coimbra, 2010, pp. 76 e 92) identifica-o como uma das dimensões dos postulados estruturantes do Estado de direito material ou como um dos corolários axiológicos de um Estado de direito; Bacelar Gouveia (Manual de Direito Constitucional, 6. ${ }^{\mathrm{a}}$ ed., II, Almedina, Coimbra, 2016, p. 823) integra a proporcionalidade no âmbito do princípio do Estado de direito, mas observa que esta não constitui "mais uma" dimensão material do mesmo, assumindo um valor próprio; ReIS NOVAIS (Princípios..., cit., p. 96) considera-o como decorrendo naturalmente do Estado de direito. Cf., porém, a visão abrangente de Jorge Miranda (Manual de Direito Consti-

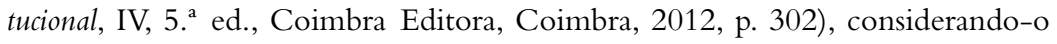
conatural à ideia de direito, ou a proposta alternativa (de pendor mais sincrético) de Vitalino Canas, O Princípio, 2017, pp. 374 ss.

3 Refletindo sobre este aspeto de uma perspetiva analítica, cf. CARLA AMADO Gomes/Dimamene de Freitas, Portugal - En Contredisant Machiavel: Le Principe de Proportionnalité et la Légitimation de l'Action Publique, Annuaire Internationale de Justice Constitutionnelle, n. ${ }^{\circ}$ 25, 2009, pp. 320 ss.

4 Cf., v. g., VRANES, Der Verhältnismäßigkeitgrundsatz: Herleitungsalternativen, Rechtsstatus und Funktionen, Archiv des Völkerrechts, 47, 2009, pp. 1 e ss.

5 Cf., v. g., VADI, Proportionality, Reasonableness and Standards of Review in International Investment Law and Arbitration, Elgar, Cheltenham, 2018 (não obliterando o relevo que a "migração de ideias constitucionais" envolve para o desenvolvimento do direito do investimento, sobretudo quando se trata, como sucede com a proporcionalidade, de conceitos que representam princípios jurídicos). 
O conteúdo do princípio da proporcionalidade continua a desvelar dissensos e a reinventar-se, em resultado das diversas incursões teorético-dogmáticas e dos influxos emergentes da prática jurisprudencial (rectius, das práticas jurisprudenciais) que, no contexto de um diálogo judicial global, se vão interpenetrando reciprocamente. Além disso, o respetivo entendimento depende do seu cruzamento com um conjunto de outras dimensões normativas, como sucede, por excelência, com o princípio da separação de poderes ou com o alcance das garantias oferecidas pelos direitos fundamentais ${ }^{6}$.

Em geral, afirma-se que o princípio da proporcionalidade relaciona meios e fins, visando responder ao problema de saber se, depois de aferida a legitimidade dos últimos, a sua consecução se pode alcançar através das medidas selecionadas, que hão de ser idóneas e exigíveis, causando mais benefícios que prejuízos. Quer dizer, o teste da adequação ou da aptidão ${ }^{7}$, postulando um juízo $e x$ ante de prognose causal ${ }^{8}$ (essencialmente - mas não só - de natureza empírica ${ }^{9}$ ), a repetir, a posteriori pelo julgador, exige que a medida se revele um mecanismo idóneo para a satisfação da finalidade dada. A referência à vertente da necessidade (ou indispensabilidade ${ }^{10}$ ) permite acentuar que, no confronto com outros meios igualmente adequados, a medida deve constituir o instrumento menos lesivo ou menos intrusivo. A proporcionalidade em sentido estrito constitui o momento azado para a ponderação custos-benefícios (a Abwägung do

$6 \quad V$. também BARAK, Proportionality, in Rosenfeld/SAjó (eds.), The Oxford Handbook of Comparative Constitutional Law, Oxford University Press, Oxford, 2012, p. 739.

7 Cf. ReIs NovaIs, Princípios, cit., p. 97, considerando mais apropriada a referência a aptidão que a adequação, por mais fielmente traduzir a ideia de Geeigneheit.

8 Hirschberg, Der Grundsatz der Verhältnismäßigkeit, Verlag Otto Schwartz \& Co., Göttingen, 1981, p. 51.

9 Kumm, Political Liberalism and the Structure of Rights: On the Place and Limits of the Proportionality Requirement, in PAVLAKOS (ed.), Law, Rights and Discourse, Hart Publishing, Portland, 2007, p. 138.

10 Aludindo ao princípio da indispensabilidade ou do meio menos restritivo, cf. ReIs Novais, Princípios..., cit., pp. 110 e ss. V. também Philippe, Le Contrôle de Proportionnalité dans les Jurisprudences Constitutionnelle et Administratives Françaises, Economica, Paris, 1990, p. 188. 
direito alemão ${ }^{11}$ o bilan coût-avantages decantado pela jurisprudência francesa ${ }^{12}$ ou a cost-benefit analysis pressuposta pela jurisprudência norte-americana ${ }^{13}$ ) e aponta no sentido do equilíbrio, da racionalidade $^{14}$ e da razoabilidade ${ }^{15}$ (reasonableness, ragionevolezza, Zumutbarkeit) da medida proposta, atentas as consequências que produz ${ }^{16}$.

11 Cf., v. g., Hirschberg, Der Grundsatz, 1981, pp. 77 e ss., 83 e ss. (cotejando o princípio da proporcionalidade em sentido estrito e o princípio da ponderação de bens ou interesses), pp. 101 ss.

12 Sobre a théorie du bilan, cf., v. g., PHILIPPE, Le Contrôle, 1990., pp. 179 e ss. Recorde-se que a primeira formulação desta doutrina - que surge como um "controlo da ausência de desproporção" - remonta ao Arrêt do Conseil d'Etat «Ville Nouvelle Est», de 28.05.1971 (in L'Actualité Juridique - Droit Administratif, 1971, pp. 420 e s.), onde, a propósito de um empreendimento urbanístico cuja realização pressupunha a expropriação e a demolição de cerca de uma centena de casas de habitação, o Tribunal declarou que "uma operação não pode ser legalmente declarada de utilidade pública senão quando os atentados à propriedade privada, o custo financeiro e, eventualmente, os inconvenientes de ordem social que ela comporta não sejam excessivos relativamente ao interesse que apresenta" (cf. p. 421; em consonância com as conclusões do Commissaire $d u$ Gouvernement Guy Braibant, que defendeu que a utilidade pública deverá ser apreciada tendo em conta o resultado - positivo ou negativo - do balanço das vantagens e inconvenientes da operação).

13 Cf., v. g., Stone et. al., Constitutional Law, 8. ${ }^{a}$ ed., Wolters Kluwer, New York, 2018, pp. 260 ss.

14 Sem prejuízo das diferenças que intercedem entre racionalidade e proporcionalidade (i.e., entre um meio escolhido em função de critérios objetivos, não arbitrários, e um meio proporcional), como já acentua DULCE LOPES, O Princípio da Proporcionalidade no Direito Comunitário: Uma Perspectiva de Controlo, polic., Coimbra, 2003, pp. 14 ss.

15 Associando já proporcionalidade em sentido estrito e razoabilidade, cf. PITSCHAS, Maßstäbe des Verwaltungshandelns, in HOFFMANN-RIEM/SCHMIDT-ASSMANN/VOSSKUHLE, Grundlagen des Verwaltungsrechts, 2. ${ }^{a}$ ed., II, Beck, München, 2012, p. 1748.

16 Como decorre do texto, a ponderação custos-beneficios pressuposta pelo princípio da proporcionalidade reveste uma natureza normativa e não económica. São, aliás, sobejamente conhecidas as insuficiências que uma estrita análise económica custos-benefícios implica no contexto mais global da limitação da atividade do poder público, desde logo, por não permitir abranger considerações insuscetíveis de mensuração monetizável - aspeto que se torna mais evidente no campo dos direitos fundamentais. E esta observação mantém-se, ainda quando se procuram construir formas de medir valores como a vida humana: cf., $v . g$, 
A ponderação custos-benefícios pretende, numa perspetiva positiva, sopesar as vantagens (para a consecução do fim) e as desvantagens implicadas pela medida, com a consequência de que quanto maiores forem os sacrifícios causados por esta, maior importância devem assumir os beneficios para a satisfação da finalidade ${ }^{17}$; e, numa ótica negativa, o princípio apela à regra segundo a qual, em situações de incerteza, deve o decisor escolher a alternativa cuja pior consequência seja superior às piores consequências das restantes ${ }^{18}$; ou, por fim, considerando uma perspetiva alternativa, o princípio pressupõe uma ponderação entre a importância do benefício social atingido pela consecução do fim subjacente à medida (satisfação do interesse público ou garantia de outro direito fundamental) e a importância social que existiria se se não restringisse o direito fundamental, num juízo que se propõe avaliar o estado desses benefícios antes e depois da restrição, comparando os respetivos efeitos marginais ${ }^{19}$.

As nuvens adensam-se em virtude de os "testes" da proporcionalidade enunciados não só pressuporem a realização de raciocínios

Sunstein, Laws of Fear: Beyond the Precautionary Principle, Cambridge University Press, New York, 2005, pp. 132 ss., exemplificando com a circunstância de, em algumas análises custos-benefícios, se quantificarem monetariamente as vidas humanas com propósitos estatísticos.

17 A formulação adotada do teste da proporcionalidade em sentido estrito numa vertente positiva aproxima-se propositadamente da law of balancing, decantada por Alexy, A Theory of Constitutional Rights, Oxford University Press, Oxford, 2010, p. 102: "the greater the degree of non-satisfaction or limitation of one principle, the greater must the importance of satisfying the other".

18 Cf., v. g., RAwLS, Uma Teoria da Justiça, Editorial Presença, Lisboa, 1993, pp. 132 e ss., a propósito da «regra maximin» (no sentido de maximum minimorum), que determina "[a ordenação d]as alternativas em função das piores de entre as respectivas consequências possíveis: devemos adoptar a alternativa cuja pior consequência seja superior a cada uma das piores consequências das outras" (Op. cit., p. 132).

19 BARAK, Proportionality, p. 745, e Proportionality: Constitutional Rights and Their Limitations, Cambridge University Press, Cambridge, 2012, pp. 350 ss. Salientando, entre nós, a importância do confronto entre os efeitos marginais ("incrementos marginais do benefício e do prejuízo de duas medidas alternativas”), $v$. ReIS NOVAIS, Princípios, pp. 134 ss. (numa perspetiva que remonta a 2003 - cf., em especial, p. 135, n. 4, e bibliografia aí citada). V. ainda Vitalino Canas, O Princípio, pp. 796 ss. 
normativos e ponderações muitíssimo complexos (que, com facilidade, resvalam do âmbito jurídico para o domínio da oportunidade política), como também se revelarem mutáveis no âmbito da resolução dos diversos problemas que a prática juspublicística vem enfrentando. Sobretudo se considerarmos que a construção (mais especificamente jurídico-constitucional) da proporcionalidade envolvendo vários juízos apresenta uma matriz essencialmente pretoriana ${ }^{20}$, não surpreenderá que o juiz constitucional (lato sensu) se veja hoje confrontado com a necessidade de retematizar tal princípio, num cenário cada vez mais vasto de Justiça Constitucional global (ou global judicial review).

\section{Os juízos de proporcionalidade desenvolvidos pela Justiça Constitucional}

O facto de circunscrevermos esta apreciação aos juízos de proporcionalidade desenvolvidos pela Justiça Constitucional não significa uma restrição ao âmbito de ação do princípio, no que tange ao controlo da sua observância pelos diversos poderes estaduais. Mesmo que se reconduza a Justiça Constitucional enquanto

20 É clássica (mas também justa) a sua recondução, na configuração comummente seguida, à jurisprudência do Bundesverfassungsgericht, que haveria culminado na célebre Apothekenurteil, de 1958 («BVerfG, 11. 6. 1958 - 1 BvR 596/56: Niederlassungsfreiheit für Apotheker», in: Neue Juristische Wochenschrift, n. ${ }^{\circ}$ 28, 1958, pp. 1035 e ss.). Relevância análoga (sobretudo sob a ótica da ponderação) reveste o Acórdão Lüth (também de 1958), o qual, partindo da conceção da Grundgesetz como expressão da Wertordnung, considerará que o sistema jurídico-privatístico se deverá interpretar à luz da Constituição (e dos direitos constitucionalmente consagrados) - a impor aos juízes dos tribunais civis/comuns uma metódica de ponderação entre direitos e interesses (in BVerGE, vol. 7, 1958, pp. 198 ss.; sobre este problema, precisamente sob a ótica da ponderação, SCHLINK, Abwägung im Verfassungsrecht, Duncker \& Humblot, Berlin, 1976, pp. 18 ss.). Sobre a jurisprudência alemã nesta matéria, cf., por todos, SCHLINK, Abwägung, pp. 49 ss.

Todavia, como se sabe, as referências à proporcionalidade mergulham mais longe na História (doutrinal e jurisprudencial): cf., v. g., LERCHE, Übermass, pp. 24 ss.; Barak, Proportionality, pp. 209 ss.; Stone Sweet/Mathews, Proportionality Balancing and Global Constitution, Columbia Journal of Transnational Law, 47, 2008, pp. 98 ss. 
realização jurídica da Constituição ${ }^{21}$ ao seu núcleo essencial - correspondente à fiscalização da constitucionalidade dos atos jurídico-públicos infraconstitucionais, efetuada por órgão(s) de natureza jurisdicional -, encontra-se aqui envolvida a apreciação de atuações não apenas de natureza legislativa, mas também administrativa (e, eventualmente - dependendo dos concretos mecanismos de Justiça Constitucional vigentes em cada ordenamento - de índole jurisdicional).

\subsection{Juízo(s) de proporcionalidade e funções do princípio: reflexão cruzada}

A compreensão do(s) juízo(s) inerentes ao princípio da proporcionalidade postula uma indagação prévia sobre as funções por aquele desempenhadas. Neste contexto, torna-se possível atribuir um duplo papel ao princípio em análise: por um lado, a sua perspetivação como cânone de interpretação, contribuindo para a concretização quer dos preceitos constitucionais (em especial, os atinentes aos direitos), quer das normas infraconstitucionais; por outro lado, a respetiva configuração como limite à atuação jurídico-pública, caracterizando-o como um parâmetro de validade e um padrão de controlo desta última

${ }^{21}$ Em sentido amplo, a Justiça Constitucional pode caracterizar-se como a realização da Constituição pelos tribunais, enquanto mobilizam os princípios e as normas constitucionais para a resolução de questões jurídico-constitucionais. Eis-nos, pois, diante de um conceito dotado de um vetor objetivo, por sua vez, (dogmático-explicativamente) dividido em duas dimensões - a realização da Constituição para a resolução de questões jurídico-constitucionais -, e de um vetor subjetivo, o qual pressupõe que esta tarefa se encontre cometida a tribunais. Sobre a Justiça Constitucional como realização jurídica da Constituição, v. os nossos trabalhos "O Problema da Realização da Constituição pela Justiça Constitucional: Ratio e Voluntas, Synépeia e Epieikeia?” (in Juízo ou Decisão? O Problema da Realização Jurisdicional do Direito, Instituto Jurídico da Faculdade de Direito da Universidade de Coimbra, Coimbra, 2016, pp. 268 ss.), e em Os Direitos Fundamentais e a sua Circunstância: Crise e Vinculação Axiológica entre o Estado, a Sociedade e a Comunidade Global, Imprensa da Universidade de Coimbra, Coimbra, 2017, pp. 138 ss. 
(a convocar, sobretudo, quando está em causa a restrição de direitos fundamentais $)^{22}$.

Assim, e enquanto cânone interpretativo, a ideia de proporcionalidade determina que o sentido conferido à norma constitucional seja adequado e razoável em face dos fundamentos que lhe estão subjacentes, e que a sua mobilização para a resolução dos casos contribua para a realização desses mesmos fundamentos. Tal significa, pois, que o princípio da proporcionalidade acaba por traçar os limites (externos) do âmbito da proteção das normas constitucionais ${ }^{23}$. Neste sentido, o princípio aproxima-se (complementando-a) da interpretação em conformidade com os princípios e abeira-se do

22 Salientando a "vertente metodológica" (methodological aspect) do princípio da proporcionalidade, BARAK (Proportionality, pp. 3 ss., pp. 7 ss., 72 ss.) distingue a diferente operatividade do princípio da proporcionalidade como cânone da interpretação (dirigido à determinação do âmbito dos direitos - interpretative balancing) e enquanto limite da restrição aos direitos (destinado a avaliar as possibilidades e as razões dessa restrição - constitutional balancing). Aludindo também à proporcionalidade como princípio interpretativo (no cenário do direito internacional e do direito europeu), cf. ARAI-TAKAHASHI, The Margin of Appreciation Doctrine and the Principle of Proportionality in the Jurisprudence of the ECHR, Intersentia, Antwerp/Oxford/New York, 2001, pp. 186 ss.

23 Kumm, Political Liberalism, p. 132. Esta dimensão revela-se especialmente importante, sob pena de o âmbito conferido a determinados direitos se tornar incontrolável: mobilizando um exemplo também avançado pelo Autor (op. cit., pp. 141 e 150), embora a outro propósito, e retirado da jurisprudência constitucional alemã, o direito ao livre desenvolvimento da personalidade não pode ter um alcance tal que compreenda o direito a montar a cavalo nas florestas públicas, o direito a alimentar pombos nas praças públicas, o direito a fumar "marijuana" ou o direito a introduzir determinada raça de cães no país; concebendo a proporcionalidade como cânone interpretativo, o conteúdo do direito ao livre desenvolvimento da personalidade há de envolver todas - mas apenas - as faculdades exigidas pelos fundamentos que o predicam (a "garantia das condições de uma individualidade autónoma e livre", incluindo a proteção geral da personalidade e de um direito geral de personalidade, bem como o reconhecimento de uma liberdade geral de ação - assim, PAUlO MOTA PINTO, O Direito ao Livre Desenvolvimento da Personalidade, in Portugal-Brasil Ano 2000, Studia Iuridica XL Boletim da Faculdade de Direito/Coimbra Editora, Coimbra, 1999, p. 164; note-se que o Autor, refletindo sobre os limites a este direito, não deixa de assinalar a relevância do princípio da proporcionalidade op. cit., pp. 223 ss. 
alcance que, em geral, conferimos à sinépica e ao problema do relevo do resultado da decisão ${ }^{24}$. A proporcionalidade visa, nessa aceção, assegurar a consonância prático-normativa entre o sentido da norma (constitucional) e a sua axiologia predicativa - aspeto que assume maior importância em normas dotadas da abertura normativa e da espessura jurídico-constitucional característica das normas atinentes aos direitos fundamentais.

Mas o princípio da proporcionalidade também se encontra na base do cânone da interpretação conforme à Constituição, possuindo, assim, impacto no desenvolvimento da tarefa interpretativa das normas infraconstitucionais. Como se sabe, tal cânone assenta não só no princípio da unidade da ordem jurídica ${ }^{25}$, como em princípios especificamente hermenêuticos, como sucede com o princípio da unidade da interpretação do sistema jurídico - a pressupor a procura e a escolha do sentido que não se revele incompatível com a Constituição. A estes associam-se igualmente princípios que relevam, em especial, da teoria da inconstitucionalidade, como é o caso do princípio do aproveitamento dos atos jurídico-públicos ou da conservação das normas, e, sobretudo, do princípio da proporcionalidade - a impor que a sanção da inconstitucionalidade (e a declaração de nulidade da norma a ela inerente) funcionem como expedientes de ultima ratio, incidindo apenas sobre atos cuja constitucionalidade falhada se revele impossível de salvar ${ }^{26}$.

Embora não se possa apartar totalmente da dimensão anterior ${ }^{27}$, o campo privilegiado da atuação da proporcionalidade respeita,

${ }^{24}$ Cf., sobre esta matéria, as considerações que tecemos em "O Problema", pp. 280 ss., e em “Os Direitos”, pp. 169 ss.

25 Hesse, Elementos de Direito Constitucional da República Federal da Alemanha, Sergio Antonio Fabris Editor, Porto Alegre, 1998, p. 72.

${ }^{26}$ Em sentido próximo, Blanco DE MORAIS, Justiça Constitucional, 2. ${ }^{2}$ ed., II, Coimbra Editora, Coimbra, 2011, pp. 885 ss. V. também Gomes CANotilho, Direito, p. 1226; Rui MedeIros, A Decisão de Inconstitucionalidade, Universidade Católica Editora, Lisboa, 1999, p. 406.

27 A Carta dos Direitos Fundamentais da União Europeia demonstra esta interligação entre ambas as dimensões do princípio da proporcionalidade, na medida em que enquadra as restrições (sujeitas ao princípio da proporcionalidade num preceito (o artigo 52..$^{\circ}$ dedicado ao "âmbito e interpretação dos direitos". 
porém, ao da apreciação da validade dos atos dos poderes públicos, em especial, das medidas que restringem os direitos com o propósito de salvaguardar outros bens jurídicos fundamentais. E é no horizonte desta dimensão que emergem as questões relacionadas com a identificação do(s) juízo(s) de proporcionalidade - desde logo, em virtude da circunstância de o funcionamento do princípio se não revelar independente da função (negativa ou positiva, defensiva ou protetiva) das normas que consagram os direitos em causa ${ }^{28}$.

\subsection{Tipologia(s) dos juizos}

As dificuldades inerentes à mobilização do princípio da proporcionalidade pelo juiz constitucional conduziram à respetiva densificação através de um conjunto de subprincípios (já enunciados supra - cf. 1.). Como decorre das considerações introdutórias, uma tal densificação visou especificar as exigências de sentido da relação meio-fim demandada pelo cumprimento da axiologia subjacente ao princípio ora em análise. Embora, neste horizonte, a proporcionalidade se encontre tradicionalmente ${ }^{29}$ associada ao designado "triplo teste" (o qual pressupõe a avaliação logicamente sucessiva da idoneidade, necessidade e da ponderação custos-benefícios), permanece, desde logo, controvertida a qualificação normativa atribuída a cada uma destas dimensões. Ademais, a experiência jurisprudencial nesta matéria (e, em particular, também a do Tribunal Constitucional português) vem demonstrando não só as diferenças intencionais

28 BARAK (Proportionality, p. 742; cf. também pp. 27 e ss.) salienta precisamente esta dimensão, apontando no sentido de que, enquanto nos direitos de natureza negativa, o princípio da proporcionalidade se dirige a avaliar se a restrição efetuada por lei ao âmbito de proteção do direito é proporcional, nos direitos positivos, está em causa aquilatar se a sua não satisfação integral é proporcional. Sobre as funções defensiva e protetiva da consagração de direitos, v., por todos, GRIMM, The Protective Function of the State, in NOLTE (ed.), European and US Constitutionalism, Cambridge University Press, Cambridge, 2005, pp. 137 ss.

29 Mas não necessariamente: pense-se, desde logo, na obra seminal de LERCHE, Übermass, passim, esp. ${ }^{\text {te }}$ p. 19 , pp. 162 ss., onde a proibição do excesso se encontra densificada pelo princípio da exigibilidade (Evfordlichkeit ou Notwendigkeit) e pelo princípio da proporcionalidade (Verhältnismäßigkeit). 
inerentes à pluridimensionalidade do princípio da proporcionalidade, como uma certa tendência evolutiva, que tende a conexioná-lo, em certos momentos (mesmo que nem sempre da forma prático-normativamente mais lograda), com outros princípios, como sucede, por excelência, com a razoabilidade, mas também com a proteção da confiança e a igualdade - a pressupor um confronto entre juízos de índole e conteúdo diversos.

\subsubsection{Questão prévia: testes, dimensões normativas ou juízos?}

A cisão do princípio da proporcionalidade em vários testes (em regra, três) não reúne o consenso, nem mesmo da doutrina nacional ${ }^{30}$ - embora corresponda à posição mais tradicional ${ }^{31}$ e seguida pela própria jurisprudência do Tribunal Constitucional.

A densidade do princípio da proporcionalidade demanda inelutavelmente uma concretização do seu conteúdo. É neste sentido que se pode aludir às respetivas dimensões normativas, i. e., precipitações das diversas exigências axiológicas subjacentes à proibição do excesso, tomada como subprincípio do princípio do Estado de direito, as quais podem surgir analiticamente divididas ou decompostas com o objetivo de orientar o intérprete. Tais dimensões normativas reclamam que o juiz constitucional, na sua tarefa de realização jurídica da Constituição, realize um conjunto de juízos destinados a aferir do cumprimento daquelas exigências. Recorde-se que, na proposta de Castanheira Neves ${ }^{32}$, o juízo traduz a "manifestação específica da intenção jurídica enquanto tal”. Transpondo agora para o problema

30 Cf., por excelência, ReIs NovaIs, Os Princípios, pp. 97 ss. (e, num epítome, pp. 98 ss.), que considera simplista e errada a recondução do princípio da proibição do excesso aos três testes tradicionais, preferindo compreender o seu conteúdo em duas dimensões (razoabilidade e proporcionalidade).

${ }^{31} V$, por último, e com revisão da doutrina nacional, Vitalino CANAS (O Princípio, pp. 46 ss.), que opta pela ideia dos segmentos para aludir à decomposição estrutural do princípio da proibição do excesso, sem prejuízo de aderir à perspetiva maioritária.

32 Castanheira Neves, Metodologia Jurídica (Problemas Fundamentais), Studia Iuridica 1, Boletim da Faculdade de Direito/Coimbra Editora, Coimbra, 1993, p. 153. 
que nos ocupa, o juízo representa o resultado de um processo reflexivo que se encontra cometido ao intérprete (in casu, ao juiz constitucional) para que possa decidir se uma determinada medida estadual se revela excessivamente intrusiva, considerando os direitos, bens ou valores que visa proteger, tendo em conta quer (a eventual existência de) outras medidas suscetíveis de alcançar a finalidade, quer o(s) impacto(s) que aquela primeira possui na esfera jurídica dos cidadãos ${ }^{33}$ e, consequentemente, os modos (positivo e negativo) como atinge os fundamentos do Estado de direito.

Não nos parece, porém, de recusar que tal processo reflexivo se possa efetuar por etapas ou "testes", destinadas à formulação de um juízo globalmente considerado de proporcionalidade ou desproporcionalidade da medida em causa. O punctum crucis reside apenas em compreender que tais fases, dimensões, "segmentos" ou "testes" são apenas dogmático-explicativamente cindíveis, embora prático-normativamente unitários. Ademais, em qualquer das suas dimensões (e avançando já algumas reflexões ulteriores), importa ter em conta que os juízos pressupostos pelo princípio da proporcionalidade (realizados, em particular, pelo juiz constitucional) assumem natureza jurídica (e não política), assentam numa racionalidade prático-normativa de fundamentação (e não numa racionalidade estratégica), louvam-se na ratio (e não na voluntas), impõem-se pela força argumentativa e não pela força do poder, pela auctoritas e não pela potestas.

\subsubsection{Em especial, o(s) juízo(s) de proporcionalidade na ótica do Tribunal Constitucional português}

A identificação do(s) juízo(s) inerentes ao princípio da proporcionalidade e o seu equilíbrio no interior do princípio podem variar em função dos sistemas jurídicos, na medida em que, como principiámos por assinalar, exprimem a específica compreensão que, em cada um deles, vigora quanto ao princípio da separação de poderes e

33 Pensamos não nos apartarmos muito de uma das propostas de ReIS NOVAIS, Os Princípios, p. 129. 
ao sentido que cada uma das funções estaduais assume na realização da Constituição ${ }^{34}$.

Eis-nos diante de uma compreensão que a análise da jurisprudência constitucional portuguesa deixa entrever com alguma clareza. No que tange ao princípio da proporcionalidade, também no nosso sistema jurídico se poderá afirmar que, em parte, o desenvolvimento das respetivas dimensões foi desvelado ou revelado pelo Tribunal Constitucional, num percurso ${ }^{35}$, que, analiticamente, poderíamos dividir em quatro fases evolutivas: afirmação, consolidação, jurisprudência da crise e (regresso à) normalização constitucional.

A) O momento de afirmação corresponde à invocação diuturna do princípio da proporcionalidade durante os primeiros vinte anos de funcionamento do Tribunal Constitucional. Louvando-se na densificação efetuada pelo Bundesverfassungsgericht e acolhida pela doutrina nacional, a jurisprudência constitucional portuguesa acolhe o desdobramento analítico (mais ou menos circunstanciado, dependendo dos arestos) do princípio em três subprincípios (adequação, exigibilidade, justa medida ou proporcionalidade em sentido estrito ${ }^{36}$, cuja apreciação pressupõe uma ordem lógica (precisamente a

34 Cf. já BARAK, Proportionality, p. 741. A questão emerge perante a diversa natureza das "aberturas normativas" contidas na Constituição (cf. a sistematização de PAulo OTero, Direito Constitucional, pp. 173 ss., destrinçando, quanto à intencionalidade e, por conseguinte, também quanto aos destinatários, entre a abertura estrutural, a abertura normativa, a abertura política, a abertura interpretativa e a abertura implementadora). Com efeito, há dimensões cujo preenchimento cabe à realização político-legislativa, outras pertencerão à realização administrativa e outras ainda implicarão a realização jurisdicional, à luz de racionalidades também distintas, de índole estratégica e instrumental (nos primeiros dois casos), de natureza prático-normativa de fundamentação, no terceiro.

35 Para uma análise aprofundada da jurisprudência do Tribunal Constitucional sobre o princípio da proporcionalidade, $v$. VitalinO CANAS, O Princípio, pp. 223 ss.

${ }^{36}$ Cf., $v$. g., entre muitos, Acórdãos n. ${ }^{\circ s}$ 25/84, ponto VI.4; 103/87, ponto 17; 455/87, pontos 4 a 7; 392/89, pontos 4.D) e E); 634/93, de ponto 5; 1182/96, ponto 2.5.; 159/2007, de 6 de março, pontos 13 e 14; 442/2007 (ponto 18, 18.1. a 18.5.); 494/2009, ponto 6.4. V. também a análise à jurisprudência do Tribunal Constitucional sob esta perspetiva empreendida por PEDRO MACHETE/ Teresa Violante, O Princípio da Proporcionalidade e da Razoabilidade na 
acabada de reproduzir), que segue uma "regra de precedência do mais abstrato perante o mais concreto, ou mais próximo (pelo seu conteúdo) da necessária avaliação das circunstâncias específicas do caso da vida que se aprecia" ${ }^{37}$ - com especial impacto na apreciação da constitucionalidade de normas de natureza penal ${ }^{38}$, mas também em caso de conflitos entre bens constitucionalmente protegidos ${ }^{39}$, e, em geral, na avaliação de medidas restritivas de direitos, liberdades e garantias ${ }^{40}$.

A retórica argumentativa da jurisprudência constitucional apresenta um interesse mais significativo enquanto procura caracterizar o fundamento e o sentido do princípio. A proporcionalidade surge concebida como um "princípio geral de limitação do poder público"41, ancorado no princípio do Estado de direito, "impondo

Jurisprudência Constitucional, também em relação com a Jurisprudência dos Tribunais Europeus, Relatório elaborada para a XV Conferência Trilateral dos Tribunais Constitucionais de Espanha, Itália e Portugal, Tribunal Constitucional, Lisboa, 2013, pp. 19 e ss. (disponível em http://www.tribunalconstitucional.pt/ tc/content/files/conferencias/ctri20131024/ctri20131024_relatorio_pt_vf.pdf). Ao sentido dos juízos de proporcionalidade desenvolvidos pelo Tribunal Constitucional também não se revela alheia a natureza da matéria: cf., v. g., MARIA JoÃo Antunes, Constituição, Lei Penal e Controlo da Constitucionalidade, Almedina, Coimbra, 2019, pp. 52 ss., a propósito da convocação do princípio no âmbito penal.

37 Acórdão n. ${ }^{\circ}$ 632/2008, ponto 11.

38 Embora nem sempre clarificando o relevo do princípio da proporcionalidade no horizonte de duas situações distintas: a norma de conduta e a norma de sanção. Salientando este aspeto (com referências jurisprudenciais), v. MARIA JoÃo ANTUnes, Constituição, p. 26, n. 25.

39 Como sucedeu paradigmaticamente nos arestos atinentes à despenalização da interrupção voluntária da gravidez: cf. Acórdãos n. ${ }^{\circ \text { s }}$ 25/84 e 85/85.

40 Para uma síntese e identificação das decisões mais relevantes nesta matéria durante os primeiros anos do funcionamento do Tribunal Constitucional, $v$. Casalta Nabais, Os Direitos Fundamentais na Jurisprudência do Tribunal Constitucional, Boletim da Faculdade de Direito, LXV, 1989, pp. 91 ss. (cf. também sobre o sentido do princípio da proporcionalidade como triplo teste à luz desta jurisprudência, op. cit., p. 68).

${ }^{41}$ Apesar de o Tribunal Constitucional salientar que também não está necessariamente apartada a sua aplicação no âmbito das relações jurídicas privadas, em virtude da configuração do princípio da proporcionalidade como "princípio objetivo da ordem jurídica”: assim, Acórdão n. ${ }^{\circ}$ 302/2001, ponto 6 (ainda que, 
limites resultantes da avaliação da relação entre os fins e as medidas públicas, devendo o Estado (também o Estado-legislador) adequar a sua acção aos fins pretendidos, e não estatuir soluções desnecessárias ou excessivamente onerosas ou restritivas"42. Trata-se de uma consequência da circunstância de, num Estado de direito, se impor que as decisões dos poderes públicos tenham "uma certa finalidade ou uma certa razão de ser, não podendo ser ilimitadas nem arbitrárias", pelo que "o princípio da proibição de excesso postula que entre o conteúdo da decisão do poder público e o fim por ela prosseguido haja sempre um equilíbrio, uma ponderação e uma "justa medida", o Estado de direito deve, pois, compreender-se como um "Estado proporcional"43.

A ideia de proporcionalidade não aparece, porém, divorciada das preocupações relacionadas com o princípio da separação de poderes. A jurisprudência constitucional acentua que o espaço de livre conformação do legislador se encontra (de)limitado, sob a perspetiva do controlo, pelo princípio da proporcionalidade, que há de fornecer, pois, as balizas (ou os alicerces) do espaço de prognose legislativa (ou nas palavras de Gomes Canotilho, "situar constitucionalmente o espaço de prognose legislativa") ${ }^{44}$, apontando para um juízo de inconstitucionalidade apenas perante hipóteses em que a medida

no caso sub iudice, o Tribunal não tenha considerado a norma em causa inconstitucional por violação do princípio da proporcionalidade).

42 Acórdão n. ${ }^{\circ} 73 / 2009$, ponto 7 . A caracterização da proporcionalidade como princípio geral dos poderes públicos permanece na jurisprudência mais recente do Tribunal Constitucional: cf., v. g., Acórdão n. ${ }^{\circ}$ 767/2019, ponto 11.

43 Acórdão n. ${ }^{\circ} 387 / 2012$, de 25 de julho, ponto 9.1. Embora este específico aresto o não mencione explicitamente, a expressão "Estado proporcional” surge já em MARia LÚCia AmARAL, $A$ Forma, p. 187. Adotando a mesma ideia, v. ainda, por exemplo, Acórdãos n. ${ }^{\text {s }}$ 494/2009, cit., ponto 6.4., e, subsequentemente (louvando-se já no aresto de 2012), 509/2015, de 13 de outubro, ponto 16; 277/2016, ponto $8 ; 362 / 2016$, de 8 de junho, ponto 14 .

44 Acórdão n. ${ }^{\circ}$ 467/91, de 18 de dezembro, ponto III, fundamentando-se também em Gomes Canotilho, Constituição Dirigente e Vinculação do Legislador: Contributo para a Compreensão das Normas Constitucionais Programáticas, 2. ${ }^{a}$ ed., Coimbra Editora, Coimbra, 2001, p. 274 (sublinhando, aliás, a ausência de incompatibilidade entre o reconhecimento da liberdade de conformação do legislador e a sua vinculação jurídico-constitucional, operada também através de princípios 
(legislativa) em causa se apresente como manifestamente excessiva ${ }^{45}$. Impor-se-á, pois, um equilíbrio entre proporcionalidade e liberdade de conformação do legislador, ao qual, em primeira linha, caberá a realização das tarefas de ponderação e em cuja sabedoria se deverá confiar $^{46}$.

B) A evolução deste posicionamento jurisprudencial culminou na fase de consolidação. Tomemos como exemplo paradigmático deste iter reflexivo o Acórdão n. ${ }^{\circ}$ 187/2001, em que o princípio da proporcionalidade surge como parâmetro de validade das normas relativas à propriedade das farmácias ${ }^{47}$. O Tribunal Constitucional salienta que as exigências da proporcionalidade variam no mesmo sentido do caráter intrusivo das restrições, pelo que aumentam perante limitações mais significativas aos direitos. Mas, em especial, esta Alta Jurisdição traça uma diferenciação clara entre a vinculação exercida pelo princípio quanto ao legislador e quanto à Administração, pressupondo a realização de juízos de controlo de intensidade distinta. $\mathrm{Na}$ verdade, reconhece-se ao legislador uma "prerrogativa de avaliação" mais ampla que à Administração (vinculada que está

jurídico-constitucionais, como o princípio da proibição do excesso: op. cit., pp. 275 e 284).

45 Cf. também Acórdãos n. ${ }^{\circ}$ 634/93, ponto 6; 83/95, ponto 9.

46 Cf. Acórdão n. ${ }^{\circ}$ 108/99, ponto 4.4.3.1.

47 Não se desconhece que, em jurisprudência anterior, se vinham adotando juízos similares (como, aliás, decorre das considerações acabadas de tecer, em texto), os quais, de algum modo, prepararam a posição assumida por este Acórdão, tirado em plenário no âmbito de um processo de fiscalização abstrata sucessiva. Assim, $v$. g., e quanto à ideia fundamental relacionada com a afirmação pelo juiz constitucional da violação do princípio da proporcionalidade por erro manifesto, cf. Acórdão n. ${ }^{\circ}$ 108/99, de 10 de fevereiro, ponto 4.4.3.1., onde se propugna, a propósito da eventual inconstitucionalidade de uma norma penal incriminadora, que esta apenas merecerá censura sub specie constitutionis, em nome do princípio da proporcionalidade, se for manifesto estar-se perante uma situação de excesso; por sua vez, a ideia da afirmação da inconstitucionalidade quando as medidas, concebidas numa lógica comparativa, fossem manifestamente excessivas ou se verificasse uma desproporção intolerável surgia aflorada em decisões anteriores (cf. Acórdãos nos 248/94, de 22 de março, ponto 2; 1182/96, de 20 de novembro, ponto 2.5.). 
à satisfação de fins heteronomamente estabelecidos); diversamente, o legislador tem competência para a definição de objetivos e para a avaliação da "relação, social e economicamente complexa, entre o teor e os efeitos das medidas". A esta conceção encontra-se associada uma consequência determinante: impedir que o órgão de controlo (in casu, o juiz constitucional) possa substituir esta avaliação por outra, pelo que, em caso de dúvida, as controvérsias não devem ser solucionadas contra a posição adotada pelo poder legislativo. Por este motivo, a afirmação da inconstitucionalidade de uma medida legislativa por violação do princípio da proporcionalidade apenas se revelará admissível quando se identifique um erro manifesto de apreciação $0^{48}$. No fundo, parece apontar-se para a defesa de uma autocontenção jurisdicional quanto ao controlo jurisdicional do cumprimento das exigências de sentido do princípio da proporcionalidade por parte do legislador, admitindo-se um controlo mais rigoroso quando se trata de medidas adotadas pela Administração (ou mesmo perante atos de jurisdição); eis-nos diante de uma posição que o Tribunal Constitucional associa à legitimidade democrática do poder legislativo e ao correspetivo maior poder de escolha ou de conformação ${ }^{49}$.

C) $\mathrm{Na}$ jurisprudência da crise ${ }^{50}$, a invocação da proibição do excesso implicou uma certa alteração principiológica e andou associada, em regra, à convocação de outros princípios jurídico-constitucionais, acabando por determinar a realização de um controlo

48 Cf. Acórdão n. ${ }^{\circ}$ 187/2001, de 2 de maio, pontos 10 e 15. Esta diferenciação de vinculações encontrava-se já presente na abordagem de Gomes CANOTILHO (Direito., p. 272), recuperada expressamente pela jurisprudência constitucional (cf., além do aresto citado, também Acórdãos n. ${ }^{\text {ss }} 484 / 2000$, de 22 de novembro, ponto $5 ; 632 / 2008$, ponto 11$)$.

49 Cf. também Pedro Machete/Teresa Violante, O Princípio, p. 16.

50 A alusão à jurisprudência da crise não reveste apenas um pendor conjuntural (destinado a identificar o lapso político-temporal em que se verificou a prolação dos arestos) ou objetivo (referindo-se ao controlo da constitucionalidade das designadas "medidas da crise"), mas possui ainda um alcance substancial, na medida em que as contingências da crise económico-financeira influenciaram o sentido decisório e a fundamentação das decisões proferidas pelo Tribunal Constitucional. Cf., a este propósito, ReIs NOvaIS, Em Defesa do Tribunal Constitucional: Resposta aos Críticos, Almedina, Coimbra, 2014, pp. 67 ss. 
conjugado de todos eles e a ausência, em alguns arestos, de uma análise específica dos subprincípios da idoneidade, necessidade e proporcionalidade em sentido estrito ${ }^{51}$.

Esta aproximação verificou-se, desde logo, entre proteção da confiança e proporcionalidade, na medida em que que o último requisito do funcionamento do princípio da proteção da confiança apela justamente a uma ponderação entre custos (para os interesses privados) e beneficios (para os interesses públicos). $\mathrm{Na}$ verdade, a afirmação da ofensa do princípio da proteção da confiança pressupõe a realização de dois tipos de juízos: a) a avaliação da existência de uma situação de confiança digna de tutela, e b) a aferição da razoabilidade da solução, aquilatada através de um balanceamento ou ponderação entre os interesses públicos (justificativos da medida) e privados (desfavorecidos pela adoção da medida) ${ }^{52}$. Verificar-se-á o requisito da confiança digna de tutela quando o Estado adote comportamentos suscetíveis gerar ou alimentar fundadas expectativas de continuidade, que serviram de base a condutas (ativas ou positivas) dos cidadãos; estará cumprida a fórmula do balanceamento

51 Se, na maioria dos Acórdãos referentes às medidas de crise, o Tribunal Constitucional se absteve de, isoladamente (i.e., sem apelo simultâneo a outros princípios jurídico-constitucionais, maxime, proteção da confiança e igualdade), efetuar os "testes" do princípio da proporcionalidade, tal já não se verificou no Acórdão n. ${ }^{\circ} 413 / 2014$, onde, a propósito da redução do montante das pensões de sobrevivência, se analisaram ex professo as dimensões de adequação, necessidade e justa medida ou proporcionalidade em sentido estrito (cf. ponto 94). Recuperando esta argumentação, cf. Acórdão n. ${ }^{\circ}$ 572/2014, pontos 16 e 17, a propósito da contribuição extraordinária de solidariedade, tendo o Tribunal aprofundado, em especial, a dimensão de proporcionalidade em sentido estrito (pontos $18 \mathrm{e}$ seguintes). Cf. ainda Acórdão n. ${ }^{\circ}$ 754/2014, ponto 17.

52 Cf., v. g., Acórdãos n. ${ }^{\circ}$ 396/2011, ponto 8, 474/2013, ponto 15, 794/2013, ponto $19,413 / 2014$, ponto $57,572 / 2014$, ponto $13,575 / 2014$, ponto 22 . Neste momento, o Tribunal Constitucional volta a recuperar a jurisprudência anterior: v. Acórdãos n. ${ }^{\text {s }} 287 / 90$, de 30 de outubro, ponto 28; 128/2009, ponto 8.2.; $188 / 2009$, ponto 3 .

Sobre a evolução do tratamento do princípio da proteção da confiança pela jurisprudência constitucional, $v$. PAULO MOTA PINTO, A Proteção da Confiança na "Jurisprudência da Crise", in GONÇAlO AlmeidA Ribeiro/Luís Pereira Coutinho (org.), O Tribunal Constitucional e a Crise: Ensaios Críticos, Almedina, Coimbra, 2014, pp. 138 ss. 
se os interesses públicos sobrelevarem os interesses privados e, por conseguinte, se as razões de interesse público justificarem a não continuidade do comportamento que induziu a situação de legítima expectativa. Ora, foi justamente neste ponto que a jurisprudência apropinquou proteção da confiança e proporcionalidade

Mas o princípio ora em análise (em especial, na dimensão de proporcionalidade em sentido estrito) surgiu igualmente associado ao princípio da razoabilidade, a pressupor a realização de um juízo avaliativo sobre as medidas impostas, tendo em consideração a esfera pessoal dos sujeitos atingidos - aspeto que conduzirá à inconstitucionalidade das soluções que impliquem uma "afetação inadmissível ou intolerável do ponto de vista de quem a sofre e por razões atinentes à sua subjetividade" "53. O Tribunal acentuou a menor intensidade que a vinculação (ou o controlo da vinculação) a este princípio reveste quando está em causa o exercício da função legislativa (em especial, no confronto com a função administrativa) - com a consequência de que, nestes casos, as medidas só padecerão de inconstitucionalidade por violação do princípio da proporcionalidade quando e se revelarem manifestamente inadequadas, desequilibradas ou desnecessárias ${ }^{54}$.

Esta atenção à esfera jurídica dos cidadãos afetados pela medida permitiu que o Tribunal aproximasse (agora de modo mais sistemático) também proporcionalidade e igualdade ${ }^{55}$ : diferenciando igualdade e igualitarismo, o Tribunal Constitucional ${ }^{56}$ (ainda que não pela primeira vez ${ }^{57}$ ) apelou para a doutrina da «igualdade proporcional»

53 Cf. Acórdão n. ${ }^{\circ}$ 413/2014, pontos 73 e 74 (a citação é do ponto 74).

54 Cf. Acórdão n. ${ }^{\circ}$ 745/2014, pontos 17 e 18, louvando-se também no Acórdão n. ${ }^{\circ} 484 / 2000$, ponto 5, e em Gomes CANOTILHO, Direito, p. 272.

55 Refletindo, em momentos anteriores, sobre o relevo da proporcionalidade na igualdade, v. GOMES CANOTILHO, Anotação ao Acórdão n. ${ }^{\circ}$ 359/91 do Tribunal Constitucional, Revista de Legislação e de Jurisprudência, n. ${ }^{\circ} 3811$, 124, fevereiro 1992, p. 327; Alves Correia, O Plano Urbanístico e o Princípio da Igualdade, Almedina, Coimbra, 1989, pp. 441 ss.

${ }^{56}$ Cf. Acórdãos n. ${ }^{\circ 5}$ 353/2012, ponto 5, e 187/2013, pontos 33 e seguintes.

57 Com efeito, a associação entre igualdade e proporcionalidade surge, inicialmente, como forma de densificação da proibição do arbítrio (que impediria medidas manifestamente desproporcionadas ou inadequadas - cf. Acórdão n. ${ }^{\circ}$ 44/84, ponto 5 invocando a posição de Figueiredo Dias em declaração de voto aposta ao parecer da Comissão Constitucional), e, posteriormente, com referência 
[a «nova fórmula» (neue Formel) do princípio da igualdade decantada pelo Bundesverfassungsgerich ${ }^{58}$ ], a qual exige, partindo da comparação das especificidades objetivas dos grupos afetados, "que se tratem por igual as situações substancialmente iguais e que, a situações substancialmente desiguais se dê um tratamento desigual, mas proporcionado". A invocação da "nova fórmula" do princípio da igualdade acaba por introduzir, na metódica de controlo deste último, as exigências de sentido do princípio da proporcionalidade, parecendo

expressa à igualdade proporcional. Assim, já o Acórdão n. ${ }^{\circ}$ 39/88 (ponto 5.3.), referia que "a igualdade não é, porém, igualitarismo. É, antes, igualdade proporcional. Exige que se tratem por igual as situações substancialmente iguais e que, a situações substancialmente desiguais, se dê tratamento desigual, mas proporcionado". Esclarecendo-se logo a seguir o alcance destas afirmações: "o princípio da igualdade não proíbe, pois, que a lei estabeleça distinções. Proíbe, isso sim, o arbítrio; ou seja proíbe as diferenciações de tratamento sem fundamento material bastante, que o mesmo é dizer sem qualquer justificação razoável, segundo critérios de valor objectivo, constitucionalmente relevantes. Proíbe também se tratem por igual situações essencialmente desiguais. E proíbe ainda a discriminação". Por sua vez, o Acórdão n. 330/93 (ponto 6) invocava diretamente a jurisprudência do Bundesverfassungsgericht sobre esta matéria, epitomando que "para se poder reconhecer um fundamento material ao desigual tratamento normativo de situações essencialmente iguais, deve aquele prosseguir um fim legítimo, ser adequado e necessário para realizar tal fim e manter uma relação de equitativa adequação com o valor que subjaz ao fim visado".

58 Completando a fórmula (correspondente à proibição do arbítrio) da metódica de controlo do princípio da igualdade, o Tribunal Constitucional alemão construiu a "nova fórmula do princípio da igualdade", nos termos da qual se verificará uma ofensa deste princípio "quando um grupo de destinatários de uma norma é tratado de forma diferente de outros destinatários, apesar de entre ambos os grupos não existir uma diferença de tal tipo e de tal peso, que possa justificar o tratamento desigual" ("wenn eine Gruppe von Normadressaten im Vergleich zu anderen Normadressaten anders behandelt wird, obwohl zwischen beiden Gruppen keine Unterschiede von solcher Art und solchem Gewicht bestehen, daß sie die ungleiche Behandlung rechtfertigen könnten”). Cf. a decisão do Bundesverfassungsgericht de 07.10.1980: «BVerfG: Präklusion von Parteivorbringen in der Berufsinstanz», in: Neue Juristische Wochenschrift, 1981, pp. 271 e s. (ponto II - 1). Refletindo sobre a evolução da metódica de controlo do princípio da igualdade, na doutrina, v., por exemplo, KUBE, Rechtliche Gleichheit und Tatsächliche Verschiedenheit, in Mellinghoff/Palm (orgs.), Gleichheit im Verfassungsstaat, C.F. Müller, Heidelberg, 2008, pp. 27 ss. 
apontar para a emergência de um controlo mais apertado por parte do Tribunal Constitucional ${ }^{59}$.

D) À mobilização significativa que o princípio da proporcionalidade conheceu durante a jurisprudência da crise (que conduziu à aglutinação de vários princípios e ao desenvolvimento de uma retórica muito própria) seguiu-se o período da normalização da jurisprudência constitucional nesta matéria, no qual se retoma o fio da densificação alcançada por cerca de quarenta anos de jurisprudência constitucional. O Tribunal vem aprimorando a sua construção inicial, embora não a abandonando ou substituindo por uma densificação normativa alternativa. Permanece a ineliminável ligação ao princípio do Estado de direito, enfatizando-se a conexão entre proporcionalidade e recusa da existência de um Estado prepotente, arbitrário e, sobretudo, injusto ${ }^{60}-\mathrm{a}$ indiciar a proporcionalidade como uma das precipitações ou concretizações possíveis da justiça (ou do sentido último do direito).

Com alguma sofisticação, a jurisprudência avança ainda no sentido do âmbito de possibilidades de mobilização do princípio, quer

59 Especialmente contundente, em geral (e não refletindo especificamente e apenas sob a perspetiva da jurisprudência da crise) quanto a este ponto, entendendo constituir uma consequência de uma não compreensão adequada das exigências de sentido do princípio da proporcionalidade, cf. ReIS NOVAIS, Princípios, pp. 91 ss. Criticando a opção do Tribunal Constitucional, cf. MigUEL NOGUEIRA DE BRITO, Medida e Intensidade do Controlo da Igualdade na Jurisprudência da Crise do Tribunal Constitucional, in Gonçalo Almeida Ribeiro/Luís Pereira Coutinho (org.), O Tribunal., pp. 107 ss., esp. ${ }^{\text {te }}$ pp. 123 ss. Considerando que existiram deficiências na aplicação do princípio da igualdade proporcional pelo Tribunal Constitucional, cf. MigUel NogUEIRA DE BRITO/ Luís Pereira Coutinho, A "Igualdade Proporcional", Novo Modelo no Controlo do Princípio da Igualdade? Comentário ao Acórdão n. ${ }^{\circ}$ 187/2013, Direito \& Política, n. ${ }^{\circ}$ 4, julho/outubro 2013, pp. 186 ss. Cf. ainda RAVI AFONSO Pereira, Igualdade e Proporcionalidade: Um Comentário às Decisões do Tribunal Constitucional de Portugal sobre Cortes Salariais no Sector Público, Revista Española de Derecho Constitucional, 98, maio/agosto 2013, pp. 317 ss., esp. ${ }^{\text {te }}$ pp. 334, 343 ss., pp. 352 ss., pp. 363 ss., apreciando criticamente a forma como o Tribunal Constitucional mobilizou a ideia de igualdade proporcional.

60 Cf., v. g., Acórdãos n. ${ }^{\text {s }} 16 / 2015$, ponto 10 , e 277/2016, ponto 8 . 
no quadro de problemas de natureza interaxiológica (em que se confrontam bens e valores constitucionalmente distintos), quer no âmbito de questões de índole intra-axiológica (em que a medida de promoção de um bem jurídico-constitucional se reconduz a um meio lesivo desse mesmo bem): clarifica-se, neste horizonte, que o princípio da proporcionalidade não se identifica com uma ponderação de bens stricto sensu (dirigida a aquilatar qual o bem prevalece sobre o outro), mas a um controlo destinado a avaliar a proporcionalidade entre o fim valioso da medida restritiva e o meio sacrificial por ela imposto ${ }^{61}$.

O Tribunal regressa igualmente à análise dos três subprincípios tradicionais ${ }^{62}$, não olvidando um especial enfoque na relevância jurídico-constitucional dos interesses prosseguidos pela norma cuja

61 Cf. Acórdão n. ${ }^{\circ}$ 396/2017, de pontos 9 e 10 (que seguimos de perto, o qual versava sobre o problema da inconstitucionalidade da norma constante do $\mathrm{n} .{ }^{\circ} 1$ do artigo $131 .^{\circ}$ do CPP que, então, previa a incapacidade absoluta para testemunhar do interdito por anomalia psíquica, mesmo quando este fosse o ofendido, independentemente do grau daquela anomalia psíquica e do seu impacto na capacidade para testemunhar - norma essa que restringia o direito à prova justamente com o propósito de garantir a integridade probatória em processo penal). Recuperando a mesma linha argumentativa, cf. Acórdão n. ${ }^{\circ}$ 669/2019, ponto 5.2.

62 Cf., v. g., Acórdãos n. ${ }^{\text {ss }}$ 277/2016, ponto 10; 123/2018, pontos 15 e 16, e, muito recentemente (louvando-se também neste último aresto), Acórdão n. ${ }^{\circ}$ 776/2019, ponto 15. O aresto debruça-se sobre uma especificidade (face à solução seguida, em geral, nas decisões de aplicação de coimas) do direito sancionatório das entidades reguladoras independentes, que consagra o efeito meramente devolutivo do "recurso" das decisões finais condenatórias - especificidade essa que, em alguns casos, surge temperada pela possibilidade atribuição de efeito suspensivo ao "recurso", condicionada, dentro de certos termos (na maioria das hipóteses, à verificação de um prejuízo considerável para o recorrente resultante da execução da decisão), à prestação de caução. Sobre esta questão, v. também o nosso trabalho "Contencioso da Regulação", in Tiago SERrÃo/José DUARTE CoImBra, Contencioso Administrativo Especial, AAFDL, Lisboa, 2020, nota 49 (no prelo).

$V$ também, para uma compreensão das dificuldades da realização, em concreto, da ponderação (entre prejuízos e benefícios) inerente ao princípio da proporcionalidade em sentido estrito, Acórdão n. ${ }^{\circ}$ 773/2019, de 17 de dezembro, ponto 5.6., e respetivas declarações de voto. Para uma apreciação dos termos do juízo de necessidade ou exigibilidade, cf., v. g., Acórdão n. ${ }^{\circ}$ 688/2019, ponto 18. 
constitucionalidade se encontra sob escrutínio ${ }^{63}$. Em certos momentos, verifica-se uma densificação mais subtil dos diversos juízos: assim sucede, $v . g$., com o juízo de idoneidade, complementado por uma ideia de essencialidade (hoc sensu, apenas se dando por cumprida esta pressuposição de sentido quando a medida se revele essencialmente - e não apenas incidentalmente - apta à satisfação do fim), ou com o juízo de proporcionalidade em sentido estrito, conjugado com uma dimensão de eficácia (avaliando-se os efeitos - mais ou menos modestos - que a medida importa para a consecução da finalidade visada $)^{64}$.

Retoma-se também a importância da mobilização de um critério de evidência quanto à ofensa ao princípio da proporcionalidade, a aplicar nos casos em que o legislador goza de um mais elevado grau de conformação legislativa ${ }^{65}$; nestes casos, exigir-se-á uma convicção clara da violação do princípio, que se assumirá como um parâmetro de controlo essencialmente negativo ${ }^{66}$. Trata-se, porém, de uma matéria que vem denotando alguma oscilação no interior da jurisprudência constitucional, pois que, embora assumindo tal dimensão, nem sempre o Tribunal convoca, na análise de uma medida concreta, aquele juízo de evidência, mesmo quando estejam em causa direitos sociais $^{67}$.

63 Cf. Acórdão n. ${ }^{\circ}$ 776/2019, ponto 15, in fine.

64 Cf. Acórdão n. ${ }^{\circ}$ 396/2017, pontos 11 e 12, também recuperado pelo Acórdão n. ${ }^{\circ} 669 / 2019$, ponto 5.2 .

65 Cf. Acórdão n. ${ }^{\circ} 767 / 2019$, ponto 11.

66 Cf. Acórdãos n. ${ }^{\text {s }} 509 / 2015$, ponto 17; 81/2016, ponto 5 (reportando-se ao último aresto citado); $277 / 2016$, ponto 8 .

67 Cf., v. g., Acórdão n. ${ }^{\circ}$ 296/2015, pontos 26 a 35 (e as declarações de voto, em especial da Conselheira Lúcia Amaral e do Conselheiro João Caupers), sobre o problema da eventual violação do princípio da proporcionalidade pela medida que condicionava a atribuição do rendimento social de inserção a não nacionais a um período mínimo (três anos) de residência em Portugal; note-se, aliás, que a mobilização do princípio da proporcionalidade na sua função interpretativa teria permitido que o Tribunal pudesse decidir se a medida em causa correspondia a uma verdadeira restrição ao princípio da equiparação consagrado no n. ${ }^{\circ} 1$ do artigo $15 .^{\circ}$ ou, diversamente, a uma simples "regulamentação" (para utilizar a terminologia invocada pela Conselheira Lúcia Amaral) ou conformação do princípio da equiparação. 


\section{Limites ao princípio da proporcionalidade: justiça e sepa- ração de poderes}

Uma análise dos juízos desenvolvidos pela jurisprudência constitucional permite destacar dois pontos essenciais, que se prendem com outros tantos limites ao princípio da proporcionalidade, os quais se reconduzem ao princípio da justiça (associado à dignidade humana) e ao princípio da separação de poderes.

Assim, e por um lado, existem medidas que se revelam totalmente incompatíveis com a identidade axiológica do Estado de direito e, como tal, não podem ser sujeitas aos "testes" do princípio da proporcionalidade, independentemente da legitimidade ou da bondade dos fins que com aquelas se pretenderia prosseguir. Assim sucederá, desde logo, quando tais medidas ofendam determinados direitos: considere-se, $v . g$, a proibição da escravatura e do trabalho forçado, ou a proibição da tortura. Estas proibições mais não são que concretizações da justiça, dos últimos redutos da dignidade humana, pelo que poderemos avançar um pouco e afirmar que qualquer medida que contrarie o princípio da justiça se encontra proibida. Está aqui presente a ideia segundo a qual o princípio da justiça, embora surja mediado por outros princípios, consubstancia algo mais que os princípios normativos igualmente constantes do texto constitucional (incluindo o princípio da proporcionalidade), possuindo um conteúdo autónomo e mais exigente que o postulado por eles, na medida em que apela à própria ideia de Direito ${ }^{68}$ e se assume como "Valor Absoluto» ${ }^{69}$. Tratar-se-á de medidas que assumem uma gravidade tal que contendem com o étimo fundante do Direito, quer por recusarem a dignidade a qualquer pessoa humana, quer

68 Kaufmann, Filosofia do Direito, Fundação Calouste Gulbenkian, Lisboa, 2004, p. 225, para quem a justiça, enquanto mais elevado valor do Direito, coincide com a própria ideia de Direito.

69 Cf., convocando a lição de Cícero (que concebe a justiça como a vera lex, recta ratio, naturce congruens, diffusa in omnes, constans, sempiterna), MARCELLO CAETANO, O Respeito da Legalidade e a Justiça das Leis, in O Direito, ano 81. ${ }^{\circ}$, fasc. $1 .^{\circ}$, janeiro/março 1949 , p. 23 , que a define como "a tal energia que a lei positiva se limita a captar e a aproveitar mas que actua na consciência de todos nós, superior à nossa vontade e independente das nossas concepções”. 
por a transformarem em instrumento de uma estratégia política ou económica ${ }^{70}$. Ou, se quisermos dizê-lo com o Tribunal Constitucional $^{71}$, a norma em causa deve apresentar "uma solução normativa absolutamente inaceitável (...), que afecte uma dada dimensão do núcleo fundamental dos interesses essenciais da pessoa humana e que colida com os valores estruturantes do ordenamento jurídico". Destarte, a violação do princípio da justiça surge numa posição de prima ratio, que afasta qualquer tentativa de equilíbrio com outros valores jurídicos, impedindo as ponderações próprias do princípio da proporcionalidade.

Por outro lado, e sem prejuízo da diversidade das situações envolvidas $^{72}$, a invocação do princípio da proporcionalidade encontra alguns limites quando confrontada com o princípio da separação de poderes. Considerando que são as medidas legislativas aquelas que mais atingem os direitos fundamentais, mas sopesando igualmente a necessidade de salvaguardar a liberdade de conformação do legislador, o juiz apenas deverá considerar contrárias à Constituição as opções

70 V. Castanheira Neves, O Papel do Jurista no Nosso Tempo, in Digesta. Escritos acerca do Direito, do Pensamento Jurídico, da sua Metodologia e Outros, I, Coimbra Editora, Coimbra, 1995, p. 44, e Questão-de-Facto - Questão-de-Direito ou O Problema Metodológico da Juridicidade, Almedina, Coimbra, 1967, pp. 576 ss. Recorde-se ainda que o "homem-pessoa" e a sua dignidade constituem a dimensão ética (a "condição ética") que confere ao direito o sentido de direito, garantindo-lhe concomitantemente a sua autonomia: uma ofensa desta condição ética - uma das condições da emergência do direito como direito (a par das condições mundano-social e humano-existencial) - implica a negação do sentido último da juridicidade. Sobre as condições de emergência do direito que aqui perfilhamos, $v$. Castanheira Neves, O Direito como Alternativa Humana. Notas de Reflexão sobre o Problema Actual do Direito, in Digesta, I, pp. 298 ss., O Direito Interrogado, pp. 51 ss., p. 61, Pessoa, Direito e Responsabilidade, in Digesta. Escritos acerca do Direito, do Pensamento Jurídico, da sua Metodologia e Outros, III, Coimbra Editora, Coimbra, 2008, pp. 154 ss., Pensar o Direito num Tempo de Perplexidade, in Liber Amicorum José de Sousa e Brito em Comemoração do $70 .^{\circ}$ Aniversário, Almedina, Coimbra, 2009, pp. 13 ss., e, muito desenvolvidamente, Coordenadas de uma Reflexão sobre o Problema Universal do Direito - ou as Condições de Emergência do Direito como Direito, in Digesta, III, pp. 31 ss.

71 Acórdão n. ${ }^{\circ}$ 363/2001, de 12 de julho, ponto 6.

72 V. Suzana Tavares Da Silva, Direitos Fundamentais na Arena Global, 2. ${ }^{a}$ ed., Imprensa da Universidade de Coimbra, Coimbra, 2014, pp. 73 ss. 
do poder legislativo que se mostrem inadequadas, desnecessárias e desproporcionais à proteção de outros bens jurídicos constitucionalmente protegidos ${ }^{73}$, sem perder de vista as diversas possibilidades de aplicação prática aos diferentes tipos de casos à mesma subjacentes ${ }^{74}$. Estamos, pois, diante de um juízo que, de alguma forma, permite circunscrever (hoc sensu, assinalar os limites constitucionais) o poder do juiz constitucional de apreciação das medidas adotadas pelas demais funções estaduais.

A possibilidade de mobilizar o princípio da proporcionalidade para o controlo da atuação do legislador também implica que aquele funcione como uma limitação negativa à ação legislativa - limitação essa que, por não implicar uma fiscalização substancial da conveniência dos atos, não determina a dissolução da discricionariedade ${ }^{75}$. $\mathrm{Na}$ realidade, a reserva do legislador só intervém perante medidas que cumpram as imposições subjacentes àqueles princípios: pensando agora no princípio da proporcionalidade, a discricionariedade só existe perante medidas que, sendo adequadas e necessárias, se assumam como equilibradas no contexto da ponderação entre custos e benefícios. A escolha da medida a adotar no caso concreto releva de um espaço de conformação do legislador, não podendo o juiz substituir a opção deste pela sua. Ao tribunal não caberá determinar qual a melhor medida para atingir o fim, mas apenas avaliar se a escolhida pelo legislador não é desproporcional para a satisfação desse mesmo fim. Por outro lado, o juízo da proporcionalidade a

74 Com esta observação pretendemos, de algum modo, dar resposta às preocupações de Reis NovaIs (Os Princípio, pp. 187 ss.), quando complementa a proporcionalidade com a razoabilidade, verificando, neste último princípio, o impacto que a medida possa ter na esfera dos sujeitos por ela afetados; de acordo com o Autor, ainda que uma medida, em abstrato e em geral, se revele proporcional, violará o princípio da razoabilidade se, na sua aplicação concreta, atingir um destinatário, impondo-lhe encargos desproporcionais em face das exigências de sentido da dignidade humana e do Estado de direito.

75 Cf. Rogério SoAres, Princípio da Legalidade e Administração Constitutiva, Boletim da Faculdade de Direito, LVII, 1981, p. 191, embora a propósito do funcionamento do princípio da proporcionalidade no âmbito da atividade administrativa discricionária e do respetivo controlo jurisdicional. 
formular pelo juiz não se poderá deixar impressionar pelas consequências (politicamente) contestáveis de determinadas medidas previstas pelo legislador, porquanto, numa democracia representativa, a censura ao mérito político do exercício da função legislativa não cabe aos tribunais, que apenas intervêm quando existe uma falha no processo democrático (de natureza substancial ou procedimental $)^{76}$.

E pensamos que o alcance do juízo de proporcionalidade não deverá variar ainda em função do processo de fiscalização em causa, assumindo uma maior intensidade, por exemplo, no caso do controlo preventivo $^{77}$. Na verdade, qualquer que seja o processo em causa, os juízos da Justiça Constitucional serão (terão de ser!) seguramente juízos que mobilizam uma racionalidade prudencial referida à juridicidade, a uma validade fundamentante que pressupõe a Constituição, como elemento desonerador, enquanto positivação possível dos fundamentos constitutivos de um dado sistema jurídico. Está agora em causa o reconhecimento da natureza verdadeiramente jurídica também do processo de fiscalização preventiva (não reconduzível a uma forma de controlo político), assim como a perceção de que o juízo de proporcionalidade efetuado pelo juiz constitucional corresponde (não à realização político-legislativa, de índole estratégica e instrumental, mas antes à) realização jurídica da Constituição.

Não ignoramos, evidentemente, que as dimensões normativas inerentes ao princípio da proporcionalidade acabam por conceder uma margem de escolha ao decisor jurisdicional ${ }^{78}$, conduzindo o tribunal a uma penetração significativa na reconstrução do juízo valorativo do legislador, sem que, com isso, se possa assistir a uma invasão da esfera própria do exercício (do núcleo essencial) da função legislativa. Por esse motivo, poder-se-á que as medidas

76 Nesta linha, cf. também Ely, Democracy and Distrust: A Theory of Judicial Review, Harvard University Press, Cambridge/London, 1980, p. 103 (apesar de o Autor colocar, compreensivelmente, a tónica na observância do due process).

77 Parecem admitir, implicitamente, esta ideia CARLA AmAdo GOMES/DinAmENE DE Freitas, Portugal, p. 338.

78 Cf., v. g., Vitalino CANAS, Proporcionalidade, pp. 616 e ss., e, com uma reflexão mais aprofundada, O Princípio, pp. 823 ss. 
legislativas só deverão considerar-se inconstitucionais (designadamente, por violação dos direitos fundamentais) quando existe uma "violação clara do princípio"79 que não passa o "teste" da razoabilidade $^{80}$ (aqui entendida no seu "sentido fraco", enquanto "válvula de segurança" "11). Não se trata de uma solução muito distante da que advoga a deferência judicial quando exista um «dissenso razoável» (reasonable disagreement) ${ }^{82}$ acerca do an e, sobretudo, do quomodo da restrição como meio para a proteção de outros bens

79 Vieira de Andrade, Os Direitos Fundamentais na Constituição Portuguesa de 1976, 6. ${ }^{a}$ ed., Almedina, Coimbra, 2019, p. 286 (itálico nosso). Trata-se de uma posição que se não identifica totalmente com aqueloutra criticada por REIS NovaIs (Em Defesa, pp. 134 ss.), que exige uma evidência manifesta da ofensa do princípio da proporcionalidade. Na verdade, propõe-se um meio-termo, que, exigindo um hard look ao juiz constitucional, não se baste com um beliscar da proporcionalidade pelo legislador.

80 Articulando já proporcionalidade e razoabilidade neste contexto, cf. SUZANA Tavares da Silva, Direitos, p. 75, e O Tetralemma do Controlo Judicial da Proporcionalidade no Contexto da Universalização do Princípio, Boletim da Faculdade de Direito, LXXXVIII-2, 2012, p. 677.

81 Sobre o "sentido fraco" (na medida em que atinge um número mais restrito de casos) da razoabilidade, entendida como válvula de segurança, cf. SADURSKI, Reasonableness and Value Pluralism in Law and Politics, in BONGIOVANNI/ SARTOR/VAlEnTini (eds.), Reasonableness and Law, Springer, Dordrecht, 2009, pp. 131 ss. (inspirando-se no Wednesbury canon do direito britânico e na manifesta irragionevolezza do direito administrativo italiano). Enfatizando a clara diferença entre proporcionalidade e razoabilidade em sentido fraco, v. BARAK, Proportionality, pp. 742 ss. (repare-se, aliás, que SADURSKI, Reasonableness, pp. 132 ss., entende que o "sentido forte" da razoabilidade pressupõe um juízo de proporcionalidade entre meios e fins).

82 Utilizamos o conceito na aceção cunhada por FALLON, Implementing the Constitution., pp. 81 s., pp. 95 ss., na senda do relevo conferido por alguma doutrina (cf., v. g., WALdron, Law and Disagreement, Clarendon Press, Oxford, 1999) ao dissenso no âmbito da realização da Constituição (a dimensão apresentada no texto é, todavia, apenas uma das três que o Autor atribui ao reasonable disagreement). A invocação deste conceito não significa, contudo, que aceitemos todas as consequências das teorias políticas do disagreement de Waldron, designadamente o facto (também apontado por HABERMAS, On Law and Disagreement. Some Comments on “Interpretative Pluralism”, Ratio Iuris, XVI-2, junho 2003, p. 189) de que, no limite, nenhum caso tem, numa perspetiva objetiva, uma só solução correta, ou a circunstância de que, em última análise, as questões relacionadas com os direitos devem ser tratadas pelo legislador e não pelos juízes (cf. FABRE, 
jurídico-constitucionalmente protegidos. E com esta posição não pretendemos substituir um princípio in dubio pro libertate $e^{83}$ por um princípio in dubio pro legislatore, ou utilizar a proporcionalidade como modo de fragilizar os direitos ${ }^{84}$, mas sublinhar tão-só que a sua violação pelo poder legislativo poderá ser jurisdicionalmente afirmada após um exame rigoroso (hard look) da medida, em consonância com a necessidade de reconduzir da função jurídica do juiz constitucional ao seu raio de ação.

The Dignity of Rights, Oxford Journal of Legal Studies, XX-2, 2000, pp. 271, 274 e s., 278).

83 Princípio que, aliás, recebeu inúmeros aplausos, mas também muitas críticas: cf., v. g., OSSENBÜHL, Grundsätze der Grundrechtsinterpretation, in MERTEN/ PAPIER (dir.), Handbuch der Grundrechte in Deutschland und Europa, I, C. F. Müller, Heidelberg, 2004, pp. 608 ss.; RAABE, Grundrechte und Erkenntnis: Der Einschätzungsspielraum des Gesetzgeberes, Nomos, Baden-Baden, 1998, pp. 252 ss.

Reações similares recebeu o congénere norte-americano: a preferred freedoms doctrine ou preferred position doctrine. Esta última surgiu justamente para contrabalançar a tradicional presunção a favor (da constitucionalidade) dos atos jurídico-públicos e constituiu um limite à deferência jurisdicional relativamente ao poder legislativo. A formulação primeira desta doutrina remonta ao célebre Acórdão da Supreme Court "United States v. Carolene Products Co.», de 25.04.1938 (in: United States Reports, 304, 1938, pp. 144 e ss.), relatado pelo Justice Stone: por um lado, afirma que, em princípio, se deve presumir a existência de factos que suportam ou justificam os juízos do legislador, apenas se considerando inconstitucional uma medida legislativa (in casu, de natureza económica) se se comprovar que existem circunstâncias suscetíveis de ilidir a presunção de que àquela medida subjaz uma base racional, que releva do conhecimento e da experiência do poder legislativo; todavia, acrescenta que esta presunção poderá não se aplicar quando estejam em causa medidas que afetem determinadas matérias (onde inclui a legislação que contenda, em geral, com as primeiras dez Emendas e a XIV Emenda e, em especial, com as liberdades de participação política e os direitos de certas minorias), as quais se encontram sujeitas a um escrutínio jurisdicional mais rigoroso (cf., esp. ${ }^{\text {te }}$, p. 152, e nota 4). Também esta posição não se revela isenta de escolhos, visto que, ao cabo e ao resto, acaba por originar uma hierarquização entre os direitos fundamentais (porque apenas alguns são preferred e não todos), e uma hierarquização que pode nem corresponder à consciência axiológica da comunidade em determinado momento histórico. cf., v. g., ACKERMAN, Beyond Carolene Products, Harvard Law Review, 98, 1985, pp. 713 ss.; Cushman, Carolene Products and Constitutional Structure, in The Supreme Court Review, janeiro 2013, pp. 321 ss.

${ }^{84}$ Cf. as pertinentes observações de KUMm, Political Liberalism, p. 142. 


\section{Princípio da proporcionalidade e Justiça Constitucional global: os novos horizontes da Justiça Constitucional}

A circunstância de as dimensões normativas do princípio da proporcionalidade e de os juízos a efetuar pelos tribunais dependerem, em certa medida, do concreto equilíbrio jurídico-constitucional estabelecido em cada ordenamento (sem prejuízo dos limites acabados de referir) não impede, porém, o que já se designou como a "globalização" ou "universalização" 85 do princípio da proporcionalidade. A paulatina internacionalização e europeização dos ordenamentos jurídicos, acompanhada de uma progressiva globalização dos problemas cuja resolução pressupõe a mediação do juiz constitucional, exigem que também a realização da Constituição espelhe essa realidade ${ }^{86}$.

Uma tal vis expansiva ou capacidade de difusão do princípio no âmbito da Justiça Constitucional representa, aliás, uma das suas características marcantes, pois não se ignora a sua conexão (praticamente seminal) com a jurisprudência do Bundesverfassungsgericht e o consequente diálogo que os juízes constitucionais nacionais com ela estabeleceram (e continuam a estabelecer), assim como os influxos recíprocos entre as várias jurisdições constitucionais. Atualmente já nem se trata apenas do reconhecimento da "europeização" "87 do princípio decorrente da confluência de culturas constitucionais (mais ou menos próximas), mas de uma capacidade de expansão para outros sistemas jurídico-constitucionais, que pode trazer algumas perspetivas renovadas.

Considere-se, $v$. g., o sentido da invocação do princípio da proporcionalidade pela Supreme Court do Canadá e o relevo assumido

85 Cf., $v$. g., SAURER, Die Globalisierung des Verhältnismässigkeitsgrundsatzes, in Der Staat, 51, 1, 2012, p. 3 ss.; KLATT/MEISTER, Verhältnismässigkeit als Universelles Verfassungsprinzip, in Der Staat, 51, 2, 2012, pp. 159 ss. Stone SwEET/ MATHEWS (Proportionality, p. 74) vão mais longe, sustentando que, a partir do final dos anos '90 do século XX, o princípio terá integrado todos os sistemas efetivos de justiça constitucional do mundo (com exceção dos Estados Unidos). Trata-se de uma temática à qual não tem sido alheia a jurisprudência constitucional portuguesa - cf. Moura RAmOs, Le Recours aux Précédents Etrangers par le Juge Constitutionnel, Boletim da Faculdade de Direito, XC-1, 2014, pp. 31 ss.

87 Gomes Canotilho, Direito, p. 267. 
no contexto do estabelecimento de um diálogo interinstitucional entre o juiz constitucional e o legislador, dada a flexibilidade que pressupõe (ou, se preferirmos, a abertura para diferentes formas de realização da Constituição ${ }^{88}$. $\mathrm{Na}$ verdade, a identificação pelo juiz de problemas de constitucionalidade na relação meio-fim representa uma oportunidade para o legislador responder com uma medida que se revele mais apta ou que satisfaça o fim de maneira mais eficaz; por sua vez, se o juiz detetar insuficiências na ponderação custos-benefícios, tal abre a possibilidade de o poder legislativo reestabelecer o equilíbrio entre meio e fim, reduzindo os impactos negativos da medida ou tornando-a idónea à prossecução de outras finalidades de interesse público ou bens constitucionalmente protegidos e, deste modo, reequilibrando a ponderação através do reforço das vantagens $^{89}$. Sem prejuízo das dificuldades que suscita (como, aliás, sucede com todas as manifestações de weak-form judicial review), quer sob a ótica da relação entre fontes (Constituição e normas infraconstitucionais), quer sob a perspetiva do relacionamento entre o legislador e o juiz constitucional (apontando para o questionamento do sentido último da Justiça Constitucional ${ }^{90}$, o diálogo interinstitucional (desenvolvido também em torno do princípio da proporcionalidade) pode corresponder, observados determinados limites ${ }^{91}$, a uma manifestação de uma «sociedade aberta dos intérpretes da Constituição»

88 Desenhado segundo um esquema análogo (embora não exatamente igual) ao disseminado a partir da jurisprudência constitucional alemã: cf., $v$. g., STONE SWEet/MATHEWs, Proportionality, p. 117; PANACCIO, The Justification of Rights Violation: Section 1 of the Charter, in OLIVER/MACKLEM/DES ROSIERS, The Oxford Handbook of the Canadian Constitution, Oxford University Press, Oxford, 2017, pp. 660 ss.

89 StOne, Canadian Constitutional Law of Freedom of Expression, in ALBERT/ CAmeron (eds.), Canada in the World: Comparative Perspectives on the Canadian Constitution, Cambridge University Press, Cambridge, 2018, p. 259, que seguimos de perto.

90 Atente-se, por exemplo, nas críticas que algumas expressões deste diálogo vêm suscitando: cf. CAMERON, Dialogue and Hierarchy, in Charter Interpretation: A Comment on R. v. Mills, Alberta Law Review, LXXXIV, 2001, pp. 1051 ss.

91 Desde logo, impeditivos de qualquer tese que subscreva um relativismo de opiniões ou perspetivas, verdadeiramente instrumentalizador da Constituição para o alcance de determinados fins ou interesses. 
(que abrange, indubitavelmente, todos os órgãos que desempenham funções estaduais) ${ }^{92}$ - "um pluralismo de intérpretes, aberto e racionalmente crítico" que assoma com uma essencialidade premente no cenário atual da interconstitucionalidade ${ }^{93}$.

Repare-se, porém, que, em alguns Estados, o reconhecimento pelas jurisdições constitucionais do princípio da proporcionalidade constitui já uma consequência da sua consagração em instrumentos ou decisões judiciais oriundos de organismos de natureza internacional ou supranacional. Assim acontece, $v$. g., no caso do Tribunal Constitucional da Bulgária e do Tribunal Constitucional da República da Macedónia, em que a invocação da proporcionalidade se louva quer na adesão à CEDH, quer, sobretudo, na sua interpretação pela jurisprudência do $\mathrm{TEDH}^{94}$. Por esse motivo, parece-nos que se torna possível avançar mais um passo e conceber os desenvolvimentos sofridos por este princípio como um contributo para a emergência de uma Justiça Constitucional global. Esta ideia encontra-se associada ao conceito de global judicial review, corporizada em instâncias judiciais internacionais ou supranacionais que desempenham uma verdadeira "função constitucional" 95 , na medida em que

92 Trata-se do conhecido título da obra de HÄBERLE, Die Offene Gesellschaft der Verfassungsinterpreten, in Verfassung als Öffentlicher Prozeß, 2. ${ }^{a}$ ed., Duncker \& Humblot, Berlin, 1996, pp. 155 ss. (esp. ${ }^{\text {te }}$ pp. 160, 162, salientando o Autor que o juiz constitucional não está sozinho na tarefa de interpretação da Constituição - p. 172), mas sem defendermos todas as consequências dogmáticas que decorrem da posição do Autor. Sobre o "pluralismo de intérpretes", com alguma contenção, cf. também Gomes CANOTILHO, «Direito Constitucional de Conflitos e Protecção de Direitos Fundamentais», in Revista de Legislação e de Jurisprudência, ano $125 .^{\circ}, 1992$, pp. 35 ss.

93 Cf. Gomes Canotilho, "Brancosos" e Interconstitucionalidade - Itinerários dos Discursos sobre a Historicidade Constitucional, 2. ${ }^{a}$ ed., Almedina, Coimbra, 2008, p. 279.

94 Cf. PAPIASHVILI, General Report: Role of the Constitutional Courts in Upholding and Applying Constitutional Principles, in XVIIth Congress of the Conference of European Constitutional Courts, Bulletin on Constitutional Case-Law - n. ${ }^{\circ}$ especial, 2018, p. v.

95 Até porque se debruçam sobre "matérias tipicamente constitucionais", como salienta Moura Ramos, O Constitucionalismo Português na Europeização, in Olhar o Constitucionalismo Português nos 40 Anos da Constituição de 1976, Instituto Jurídico, Coimbra, 2017, p. 171. Cf. ainda, equacionando o papel de 
consubstanciam tribunais que integram organizações internacionais ou supranacionais (beneficiárias da alienação de parte da soberania estadual) e que, enquanto tais, mobilizam contributos normativos que não só provêm de várias origens nacionais, como sobretudo se encontram para além das normas dos Estados nacionais ${ }^{96}$, podendo, em certos casos, assumir competência para apreciar a legitimidade das decisões destes últimos, num exercício muito especial de afirmação de prioridades normativas e de diálogo interjudicial ${ }^{97}$. A função constitucional é agora desempenhada por juízes não nacionais, chamados à definição (vertical) do relacionamento entre as várias ordens jurídicas e à integração (horizontal) dos vários sistemas de regulação setorial. E estamos diante de um fenómeno ao qual se não revela alheia a vocação tendencialmente universal de algumas instituições.

Eis o que acontece, paradigmaticamente, com a jurisprudência do TEDH que lhe confere o estatuto de «Super Tribunal Constitucional $»^{98}$ em matéria de direitos fundamentais, em consonância com a conceção que tem da CEDH enquanto "instrumento constitucional da ordem pública europeia" ${ }^{99}$ - e um tal estatuto possui

Tribunal Constitucional desempenhado pelo TJUE, CRUZ VILAÇA, Reflections on Judicial Review of the Constitutionality of EU Legislation, in EU Law and Integration: Twenty Years of Judicial Application of EU Law, Hart Publishing, Oxford/Portland, 2014, pp. 44 ss.

96 Cf. Koch JR., Judicial Review and Global Federalism, Administrative Law Review, 54, 2002, p. 502.

97 Cf. Urueña Hernandez, Global Administrative Law and the Global South, in CASSESE (ed.), Research Handbook on Global Administrative Law, Elgar, Cheltenham/Southampton, 2016, p. 404.

Repare-se, aliás, que a sobrevivência de um conjunto de ordenamentos internacionais depende da existência de estruturas jurisdicionais que fiscalizem a conformidade das decisões nacionais com determinadas normas: eis o que sucede, por excelência, no âmbito económico, designadamente com as decisões de certos órgãos da Organização Mundial do Comércio ou instituídas no âmbito do NAFTA. Cf., v.g., HAlBerstam, Local, Global and Plural Constitutionalism: Europe Meets the World, in DE BÚRCA/WEILER (eds.), The Worlds of European Constitutionalism, Cambridge University Press, Cambridge, 2012, pp. 153 ss. OSSENBÜHL, Grundsätze, p. 615.

99 Cf., v. g., Acórdão «Loizidou/Turquia (Excepções Preliminares)», de 23.03.1995, Rec. 15318/89, \$ 75; Acórdão "Al-Skeini e outros/Reino Unido», de 07.07.2011, Rec. 55721/07, \ 141 (instrument constitutionnel de l'ordre publique européenne). 
inelimináveis pontos de conexão com a mobilização do princípio da proporcionalidade.

Por um lado, o princípio da proporcionalidade constitui, em parte, a base sobre a qual assenta o sentido da evolução tendencial do sistema de proteção dos direitos humanos conferido pela $\mathrm{CEDH}$, nos termos em que aponta para a concessão de alguma deferência às jurisdições nacionais ${ }^{100}$. Neste horizonte, o problema gira em torno da doutrina da margem de apreciação ${ }^{101}$, enquanto constitui um meio para definir as relações entre este e as autoridades estaduais nacionais ${ }^{102}$. Esta referência não se dirige a identificar a margem de apreciação com a proporcionalidade, visto que a primeira releva no estabelecimento da fronteira entre o âmbito da discricionariedade conferida a um órgão nacional (legislativo, administrativo ou judicial) e o âmbito da discricionariedade do juiz internacional (in casu, do TEDH), permitindo a consideração da importância que o direito afetado assume no ordenamento jurídico do Estado em causa ${ }^{103}$. As relações entre margem de apreciação e proporcionalidade surgem na sua aplicação prática, porquanto a concessão de maior ou menor deferência aos Estados tem na sua base uma ponderação que leva

${ }^{100} \mathrm{Ou}$, nas palavras do recente Protocolo n. ${ }^{\circ}$ 15, de reconhecer que as Partes Contratantes gozam de uma margem de apreciação no que se refere à tarefa de assegurar os direitos consagrados na Convenção, ainda que "sob a supervisão do Tribunal Europeu dos Direitos Humanos". Este Protocolo ainda não entrou em vigor, porquanto a sua vigência depende da manifestação de todas as Partes Contratantes em ficarem por ele vinculadas (cf. artigo $7^{\circ}$ ). Sobre o estado atual das vinculações, cf. http://www.coe.int/en/web/conventions/ full-list/-/conventions/treaty/213/signatures?p_auth=Iq0yNptJ (último acesso em 09.02.20202).

101 Entre a inúmera bibliografia nesta temática, $v$, sobre as origens da doutrina da margem de apreciação como princípio interpretativo das normas da CEDH, $v$. a síntese de GREER, The Interpretation of the European Convention on Human Rights: Universal Principle or Margin of Appreciation?, UCL Human Rights Review, 3, 2010, pp. 2 ss.; e, agora com um olhar crítico, designadamente quanto à forma (mais ou menos indeterminada) com que o TEDH aplica o critério da margem de apreciação, cf. DELMAS-MARTY, Le Relatif et l'Universel - Les Forces Imaginantes du Droit, I, Seuil, Paris, 2004, pp. 66 ss.

${ }^{102}$ Cf., v. g., Acórdão “A. e outros/Reino Unido”, de 19.02.2009, Rec. 3455/05, $\int 184$.

${ }^{103}$ Assim, BARAK, Proportionality, p. 748. 
em linha de conta aspetos relacionados com a legitimidade democrática, a prática habitual e presente dos Estados, e a expertise ${ }^{104}$. Ora, neste contexto, não se considerarão incompatíveis com a $\mathrm{CEDH}$, em particular, medidas provenientes de Estados democráticos que, fundamentadas por razões de interesse público, não sejam manifestamente desprovidas de razoabilidade (ou proporcionalidade) ${ }^{105}$, ou que se encontrem em conformidade com os critérios desenhados pelo próprio $\mathrm{TEDH}^{106}$, admitindo ainda (e em homenagem à ideia de subsidiariedade, mas também, de ponderação e de imparcialidade em sentido objetivo) que as autoridades nacionais dos Estados, por terem um conhecimento direto da situação local, da sociedade e das suas necessidades, estejam em melhores condições de decidir que o juiz internacional (tornando desnecessário, salvo se existirem razões ponderosas, que o TEDH se substitua ao juízo das jurisdições nacionais $)^{107}$. Neste sentido, margem de apreciação e proporcionalidade representarão duas faces da mesma moeda, pelo que quanto mais intenso se mostrar o controlo da proporcionalidade, menor será a margem concedida às autoridades nacionais ${ }^{108}$.

Por outro lado, a proporcionalidade surge também ligada à ideia de democracia: sobretudo em matérias relacionadas com a liberdade de expressão (cf. artigo 10, n. ${ }^{\circ}$ 2, da $\mathrm{CEDH}$ ), o TEDH associa a

104 Trata-se da posição defendida por LEGG (The Margin of Appreciation in International Human Rights Law: Deference and Proportionality, Oxford University Press, Oxford, 2012, pp. 69 e ss.) e que aqui seguimos de perto.

${ }^{105}$ Cf. Acórdão "Janh e outros/Alemanha", de 30.06.2005, Recs. 46720/99, 72203/01 e 72552/01, S\$ 116 e 125; utilizando o critério da razoabilidade, mas agora para recusar deferência às autoridades nacionais, cf. Acórdão "Chassagnou e outros/França”, de 29.04.1999, Recs. 25088/94, 28331/95 e 28443/95, \$S 112, 113, 118 e 121.

${ }^{106}$ Cf. Acórdãos "MGN Limited/Reino Unido”, de 18.01.2011, Rec. 39401/04, $\int$ 155; "Palomo Sánchez e outros/Espanha", de 12.09.2011, Recs. 28955/06, 28957/06, 28959/06 e 28964/06, \57; “von Hannover/Alemanha (n. ${ }^{2}$ )", de 07.02.2012, Recs. 40660/08 e 60641/08, \ 107.

${ }^{107}$ Cf., v. g., Acórdãos "Hatton e outros/Reino Unido", de 08.07.2003, Rec. 63022/97, \88, e "Janh e outros/Alemanha", cit., \ 91.

108 Assim, ARAI-TAKAHASHI, The Margin, p. 14 (refletindo, nos pontos seguintes, sobre a projeção do princípio da proporcionalidade na doutrina da margem de apreciação). 
dimensão da proporcionalidade em sentido estrito à ponderação entre os prejuízos causados aos direitos afetados e os benefícios para os interesses públicos ou para o bem comum, no sentido daquilo que se revela necessário a uma sociedade democrática ${ }^{109}$.

\section{Reflexões finais}

As dificuldades inerentes ao princípio da proporcionalidade relacionam-se com a tipologia e a intensidade dos juízos que este pressupõe, sobretudo enquanto desempenha uma função de controlo (e se assume como parâmetro da validade dos atos jurídico-públicos).

$\mathrm{O}$ entendimento e o alcance a conferir ao princípio (e às respetivas dimensões) pelo juiz constitucional não prescindem do cotejo com o princípio da separação de poderes, em especial, da conjugação entre o âmbito (e os limites) da Justiça Constitucional e o poder de conformação do legislador.

As observações apontadas permitem compreender por que motivo consideramos quer o ativismo, quer a autocontenção jurisdicionais nesta matéria como patologias do sistema. Ambas as tendências correspondem a uma inobservância (por excesso ou por defeito, respetivamente) do sistema de checks and balances, assegurado pela convivência entre a autonomia do legislador e o controlo jurisdicional da validade da sua atuação. $\mathrm{Na}$ verdade, a partir do momento em que se acolhe a admissibilidade de uma fiscalização dos atos legislativos por um juiz constitucional apenas se poderá exigir que, nesta tarefa de controlo, o órgão cumpra a sua função e fiscalize as atuações legislativas (em especial, para o tema que nos ocupa, as que restringem direitos fundamentais) até aos limites da sua função (jurídica ou jurídico-normativa), embora sem nunca os ultrapassar; ou, na perspetiva oposta, e se o quisermos dizer com Alexy ${ }^{110}$, "a fiscalização da consti-

\footnotetext{
109 Salientando este aspeto, cf. ZYSSET, Freedom of Expression, the Right to Vote, and Proportionality at the European Court of Human Rights: An Internal Critique, International Journal of Constitutional Law, XVII-1, 2019, p. 234.

110 Alexy, Direitos Constitucionais e Fiscalização da Constitucionalidade, Boletim da Faculdade de Direito, LXXXVIII-2, 2012 p. 519, justamente a propósito do princípio da proporcionalidade.
} 
tucionalidade [está] confinada ao controlo dos limites da competência do legislador". Trata-se tão-só de extrair todas as consequências da conceção (que propugnamos) segundo a qual o direito constitui referente de sentido da realização da Constituição pelo juiz constitucional, referente esse que não pode ficar à mercê das orientações mais ou menos interventivas do intérprete: a realização (jurisdicional e jurídica) da Constituição há de pautar-se sempre pelo direito, não devendo satisfazer estratégias ou objetivos de natureza extrajurídica (nomeadamente, conjunturalmente política).

Salientámos que a índole marcadamente dinâmica ${ }^{111}$ do princípio the tem permitido receber novos influxos através da partilha de experiências jurisprudenciais e em resultado da assunção, pelos tribunais internacionais (ou supranacionais), de funções paralelas às dos juízes constitucionais dos Estados.

Todavia, se um dos pressupostos do princípio da proporcionalidade - a inclusão no seio do princípio do Estado de direito -, os mais recentes desenvolvimentos constitucionais demonstram que os desafios estão longe de haver terminado. A criação e posterior expansão do princípio da proporcionalidade representou uma das expressões do movimento do direito constitucional comparado e dos designados "empréstimos constitucionais", o qual acabou por obter uma disseminação muito alargada em virtude dos pressupostos valorativos que transporta. Os problemas assomam porque, atualmente, os modelos que estão a atrair novos (e menos novos...) Estados são aqueles que possuem características mais autoritárias (embora sob vestes de uma semântica democrático-constitucional), pondo em causa as dimensões essenciais do constitucionalismo ${ }^{112}$. Esta aproximação acontece, pois, apesar da mobilização do design constitucional europeu democrático e do respetivo mapa conceptual

111 Aludindo já a uma certa dimensão dinâmica (não do princípio, mas) dos graus de controlo do princípio da proporcionalidade, v. CARLA AMADO GOMES/ DinAmene De Freitas, Portugal, p. 331, embora num sentido diverso (meramente circunstancial e não necessariamente evolutivo).

112 Refletindo sobre esta matéria, v. DIXON/LANDAU, 1989-2019: From Democratic to Abusive Constitutional Borrowing, International Journal of Constitutional Law, XVII-2, 2019, pp. 489 ss. 
- determinando que, na prática, as novas autocracias utilizem este instrumentarium (e também o princípio da proporcionalidade) para legitimar e justificar a natureza apropriada das suas ações, invertendo precisamente as dimensões axiológicas inerentes àqueles princípios ${ }^{113}$. Eis o horizonte em que poderá assumir maior importância a Justiça Constitucional global, enquanto confere a instâncias como o TEDH (ou hoje também o TJUE ${ }^{114}$ ) a função de juízes constitucionais com impacto supranacional ${ }^{115}$. O princípio da proporcionalidade é, assim, renovadamente chamado a desempenhar um papel central na consolidação e defesa dos fundamentos do Estado de direito.

${ }^{113}$ Cf. DixON/LANDAU, 1989-2019, \2, referindo estarmos, neste contexto, perante "empréstimos constitucionais abusivos", focando, em especial, exemplos do direito húngaro ou polaco.

114 Cf., a propósito do TJUE como ator da global judicial review, as considerações que tecemos em Os Direitos, pp. 237 e ss.

115 Como sucedeu, paradigmaticamente, na análise da compatibilidade com o direito da União Europeia do regime polaco sobre a aposentação dos juízes (alegadamente aprovado com o propósito de afastar um conjunto de juízes do Tribunal Supremo). Cf. Acórdãos do TJUE «Comissão Europeia/República da Polónia», de 24.06.2019, P. C-619/18, esp. ${ }^{\text {te }}$ \$S 76 e ss. (considerando inclusivamente que a medida em causa não é justificada por um motivo legítimo - cf. \ 96); «Comissão Europeia/República da Polónia», de 09.11.2019, P. C-192/18, esp. $^{\text {te }}$ SS 113 e ss., quanto à mobilização do princípio da proporcionalidade e as possibilidades de restrição do direito à inamovibilidade dos juízes. 


\section{Juízos de proporcionalidade e de razoabilidade à luz dos artigos $7 .{ }^{\circ}$ e $8 .^{\circ}$ do Código do Procedimento Administrativo}

Sandra Lopes Luís*

SUMÁRIO: 1. As alterações operadas pelo Decreto-lei n. ${ }^{\circ} 4 / 2015$, de 7 de Janeiro: o art. $7 .^{\circ}$ e o art. $8 .^{\circ}$ do Código do Procedimento Administrativo; 2. Juízos de proporcionalidade e juízos de razoabilidade; 2.1. Diversidade terminológica; 2.2. Diferenças estruturais entre juízo de proporcionalidade e juízos de razoabilidade; 2.2.1. Diversidade conceptual; 2.2.2. Os possíveis sentidos dados ao princípio da razoabilidade; A) Equiparação ao princípio da proporcionalidade; B) Distinção face ao princípio proporcionalidade; 2.2.3. A autonomização da razoabilidade face à proporcionalidade; A) Origens do princípio razoabilidade; B) Sentido da razoabilidade no art. $8 .^{\circ}$ do CPA; C) O entendimento do princípio da razoabilidade pela jurisprudência; D) Diferenças entre juízos de proporcionalidade e juízos de razoabilidade; 3. Considerações finais.

1. As alterações operadas pelo Decreto-lei n. ${ }^{\circ} 4 / 2015$, de 7 de Janeiro: o art. $7 .^{\circ}$ e o art. $8 .^{\circ}$ do Código do Procedimento Administrativo

O Decreto-lei n..$^{\circ}$ 4/2015, de 7 de Janeiro, operou importantes modificações ao Código do Procedimento Administrativo (doravante

* Professora Auxiliar Convidada da Faculdade de Direito da Universidade de Lisboa. Investigadora Principal do Centro de Investigação de Direito Público. 
$\mathrm{CPA}$ ), entre as quais se incluem alterações ao princípio da proporcionalidade, a densificação do princípio da justiça e a positivação do princípio da razoabilidade.

Efectivamente, se o antigo art. $5 .^{\circ}$, n. $^{\circ}$ 2, do CPA, com epígrafe princípio da igualdade e da proporcionalidade, dispunha que "as decisões da Administração que colidam com direitos subjectivos ou interesses legalmente protegidos dos particulares só podem afectar as posições em termos adequados e proporcionais aos objectivos a analisar", dando conta apenas de duas das dimensões do princípio da proporcionalidade, o actual art. 7. ${ }^{\circ}$ do CPA, dedicado exclusivamente ao princípio da proporcionalidade, ao dispor no número 1 que "Na prossecução do interesse público, a Administração Pública deve adotar os comportamentos adequados aos fins prosseguidos" e no número 2 que "As decisões da Administração que colidam com direitos subjetivos ou interesses legalmente protegidos dos particulares só podem afetar essas posições na medida do necessário e em termos proporcionais aos objetivos a realizar", passa a acolher as três dimensões do princípio da proporcionalidade, isto é, a adequação, a necessidade e a proporcionalidade em sentido estrito. Por sua vez, enquanto o antigo artigo $6 .^{\circ}$ do CPA, com epígrafe princípio da justiça e da imparcialidade, limitava-se a afirmar que "no exercício da sua actividade, a Administração Pública deve tratar de forma justa e imparcial todos os que com ela entrem em relação", o actual art. 8. 'do CPA, com epígrafe princípio da justiça e da razoabilidade, dispõe que "A Administração Pública deve tratar de forma justa todos aqueles que com ela entrem em relação, e rejeitar as soluções manifestamente desrazoáveis ou incompatíveis com a ideia de Direito, nomeadamente em matéria de interpretação das normas jurídicas e das valorações próprias do exercício da função administrativa", associando, assim, a razoabilidade ao princípio da justiça.

São estas disposições que constituem mote para o presente texto, pois o facto de a ideia de razoabilidade vir muitas vezes associada ao princípio da proporcionalidade, assimilando-se à sua dimensão de proporcionalidade em sentido estrito, ou, em alternativa, autonomizando-se como uma sua quarta dimensão, leva-nos a reflectir acerca da natureza dos juízos de proporcionalidade e dos juízos de razoabilidade que estão subjacentes aos artigos $7 .^{\circ}$ e $8 .^{\circ}$ do CPA. 


\section{Juízos de proporcionalidade e juízos de razoabilidade ${ }^{1}$}

\subsection{Diversidade terminológica}

Para mais facilmente inserirmos o tema, vamos começar por analisar a diversidade terminológica usada pela doutrina portuguesa relativamente a cada um dos princípios.

Assim, se, quanto ao princípio da proporcionalidade, há quem fale em proibição do excesso ${ }^{2}$, tendo em conta o art. $18 .^{\circ}$, n. $^{\circ} 2$, da Constituição da República Portuguesa (CRP), enquanto princípio com uma dimensão maior que contém várias dimensões, entre as quais se destacam a adequação ou idoneidade, a necessidade ou exigibilidade, a proporcionalidade em sentido estrito ${ }^{3}$ ou princípio da

1 Sobre a distinção na doutrina estrangeira, entre outros, vide: PAUL P. CRAIG, The Nature of Reasonableness Review, in Current Legal Problems, (2013), pp. 1-37; JEFFREY JOWELL/ANTHONY LESTER, Beyond Wednesbury: substative principles of administrative law.in 14 Commonwealth Law Bulletin, April 1988, pp. 858-870; Garry Downes AM, Reasonableness, Proportionality and Merits Review - New South Wales Yong Lawyers Seminar Issues of Administrative Law, 28 September 2008, pp. 1-14; Katharine G. Young, Proportionality, Reasonableness, and Economic and Social Rights, in Proportionality: New Frontiers, New Challenges, forthcoming (2017), pp. 1-35; MARTA CARTABIA, I principi di ragionevolezza e proporzionalità nella giurisprudenza costituzionale italiana, Conferenza trilaterale delle Corte costituzionali italiana, portoghese e spagnola, Roma, Palazzo della Consulta 24-26 ottobre 2013, pp. 1-19; FRANCESCO NICOTRA, I principi di proporzionalità e ragionevolezza dell'azione amministrativa, in federalismi.it - Rivista di diritto pubblico italiano, comunitario e comparato, n. ${ }^{\circ}$ 12, giugno 2017, pp. 1-24; GIULIA SPARAPANI, Ragionevoleza e proporzionalità: storia italiana di un incontro tra $i$ due baluardi del costituzionalismo moderno, Filodiritto, Bologna, 20 Novembre 2020, pp. 1-21.

2 Cfr. Jorge Reis Novais, Os Princípios Constitucionais Estruturantes da República Portuguesa, Coimbra, 2004, pp. 161 e segs; Vitalino Canas, O Princípio da Proibição do Excesso na Conformação e no Controlo de Atos Legislativos, Coimbra, 2017; e J. J. Gomes CANotilho, Direito Constitucional e Teoria da Constituição, $7^{\text {a }}$ ed. (reimp), Coimbra, 2003, pp. 266 e segs.

3 Note-se que, em Itália, FRANCESCO NiCOTRA autonomiza a razoabilidade da proporcionalidade e defende que os pressupostos de aplicação desta são a idoneidade, a necessidade e a adequação, corespondendo este último a um justo equilibrio entre os interesses a tutelar, cfr. FRANCESCO NICOTRA, I principi di proporzionalità e ragionevolezza dell'azione amministrativa, in federalismi.it - Rivista 
justa medida ${ }^{4}$ e, ainda, para alguns, a dimensão da razoabilidade ${ }^{5}$; por outro lado, há quem use a expressão proporcionalidade em sentido amplo, abrangente das dimensões da adequação ou idoneidade, da necessidade ou exigibilidade e da proporcionalidade em sentido estrito ${ }^{6}$. Para além disso, há ainda quem, a respeito da dimensão da necessidade, fale em proibição do excesso $^{7}$ e outros que tratam a terceira dimensão da proporcionalidade em sentido estrito como razoabilidade ${ }^{8}$; havendo, inclusivamente, a este respeito, quem defenda que esta razoabilidade, enquanto variante da proporcionalidade, é a razoabilidade que se relaciona com a justiça introduzida no art. $8 .^{\circ}$ do $\mathrm{CPA}^{9}$. E, por fim, há quem use a expressão razoabilidade para

di diritto pubblico italiano, comunitario e comparato, n. ${ }^{\circ}$ 12, giugno 2017 , pp. 8 e 10 .

4 Cfr. J. J. Gomes Canotilho, Direito Constitucional e Teoria da Constituição, $7^{\mathrm{a}}$ ed. (reimp), Coimbra, 2015, p. 270.

5 Cfr. Jorge Reis Novais, Os Princípios Constitucionais Estruturantes da República Portuguesa, Coimbra, 2004, pp. 186 e segs.

6 Cfr. Luís Filipe COlaÇo ANTUNES, Interesse público, proporcionalidade e mérito: relevância e autonomia processual do princípio da proporcionalidade, in Estudos em homenagem à Professora Doutora Isabel Magalhães Collaço, vol. II, Coimbra, 2002, pp. 546 e segs; Luiz S. Cabral De Moncada, Código do Procedimento Administrativo anotado, Coimbra, 2015, p. 93 e segs; e MÁrIO EsTEVES DE Oliveira/Pedro Costa Gonçalves/J. Pacheco de Amorim, Código de Procedimento Administrativo Anotado, $2^{a}$ ed., 1997, p. 104.

7 Cfr. Paulo Otero, Direito do Procedimento Administrativo, vol. I, Coimbra, 2016, pp. 176 e 177.

8 Cfr. Marcelo Rebelo de SOUSA/André Salgado de Matos, Direito Administrativo Geral - Introdução e Princípios Fundamentais, tomo I, Lisboa, 2006, pp. 207 e segs.

9 Neste sentido, FAUSTO DE QUADROS refere-se a quatro variantes da proporcionalidade que se interpenetram entre si: a necessidade; a adequação; a razoabilidade ou proporcionalidade em sentido estrito; e a proibição do excesso, cfr. Fausto de Quadros/ José Manuel Sérvulo Correia/ José Carlos Vieira de Andrade / Rui Chancerelle de Machete/ Maria da Glória Garcia/ Mário Aroso de Almeida/ José Miguel Sardinha/ António Políbio Henriques, Comentários à Revisão do Código do Procedimento Administrativo, Coimbra, 2016, p. 35. 
caracterizar a medida de ponderação entre os custos e benefícios na proporcionalidade em sentido estrito. ${ }^{10}$

Posto isto, a questão que se coloca, face ao tema que estamos a tratar, é a de saber se a razoabilidade, tal como prevista no art. $8 .^{\circ}$ do CPA, corresponde efectivamente a uma das dimensões da proporcionalidade, tal como entendida por alguns autores, tanto na dimensão da proporcionalidade em sentido estrito, como, eventualmente, no âmbito de uma dimensão da proporcionalidade autónoma desta última. E, neste âmbito, mais concretamente, importa determinar quais diferenças estruturais existem, ou poderão existir, entre juízos de proporcionalidade e juízos de razoabilidade, uma vez que, não raro, as expressões são usadas indiferenciadamente.

\subsection{Diferenças estruturais entre juízos de proporcionalidade e juízos de razoabilidade}

\subsubsection{Diversidade conceptual}

Antes de perscrutar acerca dos termos em que se poderá operar uma distinção e autonomização entre juízos de proporcionalidade e juízos de razoabilidade, vamos verificar de que modo os conceitos de proporcionalidade e de razoabilidade podem ou não remeter para realidades diversas.

A expressão "proporcionalidade" provém do latim "proportionale" e afigura-se como a característica do que é proporcional, pressupondo proporção, harmonia e simetria, e implicando uma relação com outra grandeza ou variável. Por sua vez, a expressão "razoabilidade" é uma característica do razoável, que implica uma conformidade à razão, remetendo para algo comedido, ponderado, justo, aceitável e acima do medíocre. Deste modo, pode, desde logo, afirmar-se que enquanto a proporcionalidade é um conceito relacional, que

10 A este respeito, PaUlo Otero dá conta que não deve haver “....uma desrazoável ou desequilibrada ponderação entre interesses, custos (ou inconvenientes) e beneficios (ou vantagens) dela resultantes...", cfr. PAUlo OTERO, Direito do Procedimento Administrativo, vol. I, Coimbra, 2016, p. 177. 
pressupõe uma harmonia com outra realidade, a razoabilidade é um conceito valorativo, que faz apelo a juízos de justiça.

\subsubsection{Os possíveis sentidos dados ao princípio da razoabilidade}

Tendo presente este ponto de partida, urge olhar mais atentamente para o modo como a doutrina tem relacionado a razoabilidade com a proporcionalidade.

\section{A) Equiparação ao princípio da proporcionalidade}

Nestes termos, seguindo o já exposto, há quem entenda que a razoabilidade constitui uma das dimensões do princípio da proporcionalidade em sentido amplo (ou proibição do excesso) ${ }^{11}$, podendo corresponder à dimensão da proporcionalidade em sentido estrito ou equilíbrio ${ }^{12}$, ou corresponder a uma outra dimensão autónoma desta, designada, precisamente, de razoabilidade $\mathrm{i}^{1 / 14}$.

11 Porém, no sentido de que a proporcionalidade pode ser encarada como uma refracção da razoabilidade, vide KATHARINE G.Young, Proportionality, Reasonableness, and Economic and Social Rights, in Proportionality: New Frontiers, New Challenges, forthcoming (2017), p. 12.

12 Neste sentido, vide MIKE WIENBRACKE, Der Verhältnismaßigkeitsgrundsatz, in Zeitschrift für das Juristische Studium (ZJS) 2/2013, pp. 152 e segs; FAUSTO de Quadros, in Fausto de Quadros/ José MANuel SÉrVulo Correia/ José Carlos Vieira de Andrade / Rui Chancerelle de Machete/ maria da Glória Garcia/ Mário Aroso de Almeida/ José Miguel SARdinha/ António Políbio HenriQues, Comentários à Revisão do Código do Procedimento Administrativo, Coimbra, 2016, p. 35; e MARCElo Rebelo DE SOUSA/ANDrÉ SAlgado de MATOs, Direito Administrativo Geral - Introdução e Princípios Fundamentais, tomo I, Lisboa, 2006, p. 207.

13 Assim, Jorge ReIs Novais, Os Princípios Constitucionais Estruturantes da República Portuguesa, Coimbra, 2004, pp. 187 e segs.

14 Note-se que esta também tem sido a posição da jurisprudência constitucional portuguesa, que tanto equipara a razoabilidade à proporcionalidade em sentido estrito (neste sentido, vide o acórdão do Tribunal Constitucional n. ${ }^{\circ}$ Acórdão n. ${ }^{\circ}$ 159/2007), como a autonomiza enquanto quarta dimensão do princípio da proibição do excesso (neste sentido, vide o acórdão do Tribunal Constitucional n. ${ }^{\circ}$ Acórdão n. ${ }^{\circ}$ 413/2014). 
Ao ser identificada como proporcionalidade em sentido estrito, a razoabilidade, enquanto terceiro teste da proporcionalidade, significa que, tal como resulta do art. $7 .^{\circ}$, n. $^{\circ}$ 2, do CPA, "As decisões da Administração que colidam com direitos subjetivos ou interesses legalmente protegidos dos particulares só podem afetar essas posições... em termos proporcionais aos objetivos a realizar", o que implica, mais concretamente, que se faça uma estimativa ou ponderação equilibrada entre os benefícios para o interesse público com a adopção de certa medida e os prejuízos infligidos ao particular com essa mesma medida, de modo que, a razoabilidade implicaria esta ponderação equilibrada entre os interesses públicos e os interesses privados, traduzindo, nas palavras de J. J. GOMES CANOTILHO, uma "justa medida"15.

Em sentido inverso, como verificámos, há quem defenda que, além desta proporcionalidade em sentido estrito, a proporcionalidade em sentido amplo, ou proibição do excesso, tem uma dimensão autónoma de nome razoabilidade. Esta razoabilidade implica que, para aferir a tolerância de certa medida, se faça um juízo centrado exclusivamente na esfera do afectado ${ }^{16}$, independentemente dos efeitos positivos para o interesse público. ${ }^{17}$ Trata-se de um juízo aplicado de forma absoluta ou categórica, feito sem o contrapeso de bens ou valores colidentes, isto porque um acto com características gerais e abstractas pode ser proporcional no contrapeso entre efeitos positivos e negativos, mas já ser intolerável na esfera do particular dele destinatário, afigurando-se, por este motivo, desrazoáve ${ }^{18}$. Entendida desta forma, a razoabilidade traduz um juízo subjectivo centrado nos

15 Cfr. J. J. Gomes Canotilho, Direito Constitucional e Teoria da Constituição, $7^{\mathrm{a}}$ ed. (reimp), Coimbra, 2015, p. 270.

16 Diz respeito à específica situação desvantajosa em que a medida coloca o afectado.

17 Cfr. Vitalino Canas, O Princípio da Proibição do Excesso na Conformação e no Controlo de Atos Legislativos, Coimbra, 2017, pp. 1179 e segs.

18 Neste sentido, JORGE REIS NOVAIS dá como exemplo o caso da imposição aos contribuintes da cedência de uma percentagem dos seus impostos à subvenção de certa confissão religiosa, no caso de esta se afigurar estranha ao contribuinte ou de este com ela discordar, cfr. JORge Reis Novais, Os Princípios Constitucionais Estruturantes da República Portuguesa, Coimbra, 2004, p. 188. 
prejuízos que certa actuação poderá causar na esfera de certo sujeito em particular, detendo, por isso, uma dimensão valorativa ${ }^{19}$.

A este respeito, vemos de pouca utilidade uma autonomização da razoabilidade enquanto quarta dimensão do princípio da proporcionalidade, pelo facto de o seu conteúdo se encontrar absorvido pela dimensão da proporcionalidade em sentido estrito, dado que esta, ao implicar uma ponderação entre as vantagens para o interesse público com a adopção duma certa medida e as desvantagens para os destinatários afectados com ela, não deixa de ter em conta também os efeitos negativos sobre estes indivíduos, que são aferidos através de parâmetros subjectivos ${ }^{20}$. Para além de que, uma análise centrada exclusivamente nos efeitos causados na esfera do particular afectado pode subverter a ponderação efectuada na terceira dimensão da proporcionalidade, pondo-se em causa o interesse público subjacente à adopção de certa medida.

\section{B) Distinção face ao princípio proporcionalidade}

Com posição oposta ao ora referido, há quem, pura e simplesmente, não fale em razoabilidade nem use a expressão razoabilidade para designar qualquer uma das dimensões do princípio da proporcionalidade (ou da proibição do excesso), entendendo que tal suposto princípio não acrescentaria nada a este último ${ }^{21}$. E outros há que, em

19 Cfr. Jorge ReIs Novais, Os Princípios Constitucionais Estruturantes da República Portuguesa, Coimbra, 2004, p. 189.

20 A este respeito, veja-se o exemplo da importação de quatro pés de sofá avançado por HUMBERTO Ávila para defender que a norma que determina a supressão de benefícios fiscais a empresas que importem produtos estrangeiros viola a dimensão da proporcionalidade em sentido estrito, quando aplicada a uma empresa que importou uma única vez quatro pés de sofá. Neste caso, os efeitos jurídicos que se projectam na esfera da empresa são manifestamente desproporcionados em relação aos benefícios que resultam da sua aplicação para o interesse geral, não sendo preciso recorrer à figura adicional da razoabilidade. Cfr. HUMBERTO ÁviLA, Teoria dos princípios: da definição à aplicação dos princípios jurídicos, $7^{\mathrm{a}}$ ed., São Paulo, 2007, p. 145.

21 Cfr. Carlos Blanco De Morais, Curso de Direito Constitucional - Teoria da constituição em tempo de crise do estado social, $2^{\mathrm{a}}$ ed, tomo II, vol. II, Coimbra, 2014, pp. 475 e segs. 
sentido oposto, apoiando-se no novo art. $8 .^{\circ}$ do CPA, defendem a valia da existência autónoma do princípio da razoabilidade, enquanto princípio distinto do princípio da proporcionalidade, considerando que tal princípio apenas implicaria um teste de relevância, e não de ponderação, que se afigura como um parâmetro de controlo menos intenso dos actos discricionários, próximo da "reasonableness" dos países da common law e com uma especial importância ao nível das políticas públicas ${ }^{22}$.

\subsubsection{Autonomização da razoabilidade face à proporcionalidade}

\section{A) Origens do princípio}

O princípio da razoabilidade foi desenvolvido originariamente nos ordenamentos jurídicos de matriz anglo-saxónica, onde, em respeito escrupuloso pelo princípio da separação de poderes, era usado para o controlo dos actos discricionários das entidades administrativas, designadamente quando estas actuavam de forma arbitrária e em desconformidade para com o Direito. ${ }^{23}$ Deste modo, em tais países, só posteriormente o princípio da proporcionalidade foi objecto de estudo, sendo usado, especialmente, para a defesa dos direitos dos particulares ${ }^{24}$.

22 Designadamente para combater a judicialização das políticas públicas, cfr. SuZANa TAVARES DA SILVA, O princípio da razoabilidade, in Comentários ao Novo Código do Procedimento Administrativo (CARla Amado Gomes/AnA FERnANDA Neves/Tiago SERRÃo coord.), $2^{a}$ ed., Lisboa, 2015, pp. 208 e segs.

23 A este respeito, vide FEDERICO FABBRINI, Reasonableness as a Test for Judicial Review of Legislation in the French Constitutional Council, in Journal of Comparative Law, 2009, pp. 42 e segs; MICHAL BOBEK, Reasonableness in Administrative Law: a comparative reflection on functional equivalence, - Eric Stein Working Paper No 2/2008, pp. 3 e segs; SUZANA TAVARES DA SILVA, O princípio da razoabilidade, in Comentários ao Novo Código do Procedimento Administrativo (Carla Amado Gomes/Ana Fernanda Neves/Tiago Serrão coord.), 2a ed., Lisboa, 2015, pp. 216 e 217.

24 Sobre o reconhecimento do princípio da proporcionalidade pelos tribunais ingleses, vide ; JEFFREY JOWELL/ANTHONY LESTER, Beyond Wednesbury: substative principles of administrative law.in 14 Commonwealth Law Bulletin, April 1988 , pp. 863 e segs. 
Em sentido inverso, na maior parte dos ordenamentos jurídicos de matriz romano-germânica, e de modo particular no alemão, de cariz mais garantístico, começou por fazer-se um estudo primacial do princípio da proporcionalidade, "Verhältnismaßigkeits" apenas sendo tratada mais tarde a razoabilidade, enquanto variante densificadora do primeiro. ${ }^{25 / 26}$

Sendo assim, é manifesto que os dois princípios têm um cunho originário diverso, aspecto que certamente será relevante para a sua diferenciação.

\section{B) Sentido da razoabilidade no art. $8 .^{\circ}$ do $C P A$}

$\mathrm{O}$ art. $8 .^{\circ}$ do CPA, com epígrafe princípio da justiça e da razoabilidade, optou por densificar o princípio da justiça e por autonomizar o princípio da razoabilidade, associando, claramente, a razoabilidade à ideia de justiça ao considerar que " $A$ Administração Pública deve tratar de forma justa todos aqueles que com ela entrem em relação, e rejeitar as soluções manifestamente desrazoáveis ou incompatíveis com a ideia de Direito, nomeadamente em matéria de interpretação das normas jurídicas e das valoraçooes próprias do exercício da função administrativa".

Efectivamente, a Constituição de 1976 fez transitar a justiça da esfera do mérito para a esfera da legalidade, afirmando-a como um princípio geral que expressa a ideia do Direito. A justiça configura um conceito indeterminado, de difícil densificação, que, em termos genéricos, implica a verificação da negação da juridicidade, da dignidade humana ou dos direitos fundamentais. Este princípio é

25 Vide, entre outros, MIKE WIENBRACKE, Der Verhältnismaßigkeitsgrundsatz, in Zeitschrift für das Juristische Studium (ZJS) 2/2013, pp. 148 e segs; ALDO SANDUlli, La Proporzionalità dell'azione amministrativa, Padova, 1998, pp. 44 e segs; ElEnA BUOSO, Il dialogo tra Corti in Europa e L'emersione della Proporzionalitá amministrativa, in AAVV "Dialogo tra Corti e principio di proporzionalità", Padova, 2013, p. 405-434; e Vitalino CANAS, O Princípio da Proibição do Excesso na Conformação e no Controlo de Atos Legislativos, Coimbra, 2017, pp. 71 e segs.

26 Sobre as razões do desenvolvimento dos princípios da razoabilidade e da proporcionalidade nos países da common law e nos países de matriz romano-germânica, vide MICHAL BOBEK, Reasonableness in Administrative Law: a comparative reflection on functional equivalence, - Eric Stein Working Paper No 2/2008, p. 11. 
habitualmente entendido em dois sentidos: um sentido mais amplo, segundo o qual os juízos de justiça integram os demais subprincípios concretizadores da ideia de Direito, designadamente as ideias de igualdade, proporcionalidade e imparcialidade; e um sentido mais restrito, que diz respeito à equidade (justiça do caso concreto) e à necessidade de atender às particularidades e interesses envolvidos nas situações de facto. ${ }^{27}$

A jurisprudência administrativa não tem dado uma grande relevância ao princípio da justiça enquanto factor autónomo de invalidação das condutas administrativas. De facto, se originariamente o reconduzia aos casos da violação de outros princípios, designadamente à violação do princípio da protecção de confiança, posteriormente, com a constitucionalização dos princípios da proporcionalidade e da igualdade, em 1989, e com a constitucionalização do princípio da boa fé, em 1997, verificou-se um progressivo esvaziamento do princípio da justiça enquanto princípio autónomo.

Deste modo, o princípio da justiça tem sido utilizado pelos tribunais administrativos, normalmente, como fundamento adicional da anulação de actos administrativos que violam outros princípios ${ }^{28}$, remetendo-se a sua valia autónoma para os casos de "manifesta e notória injustiça", quando ocorra uma situação que "fira o mínimo ético de justiça que é comum da consciência humana e social”, isto é, casos em que é o critério usado é "manifestamente desacertado e inaceitável”29. Tal circunstância justifica que a valia do princípio da

27 Neste sentido, Paulo Otero refere que o princípio da justiça impõe um agir administrativo conforme à equidade ou justiça do caso concreto, devendo atender às situações de facto e interesses em presença, cfr. PAUlo OTERO, Direito do Procedimento Administrativo, vol. I, Coimbra, 2016, p. 220.

28 Mas sem que se demonstre a sua concreta da sua violação, vide, entre outros, o acórdão do Supremo Tribunal Administrativo de 16.06.2004, P. 02060/03. A este respeito, vide também MARCELO Rebelo De Sousa/André SAlgado De Matos, Direito Administrativo Geral - Introdução e Princípios Fundamentais, tomo I, Lisboa, 2006, p. 222; e PAulo Otero, Direito do Procedimento Administrativo, vol. I, Coimbra, 2016, p. 221.

29 Assim, no acórdão do Supremo Tribunal Administrativo de 15.03.2001, P. 044018, refere-se que "Só se justifica o controle do S.T.A. nos casos de manifesto ou notória injustiça, em que a classificação atribuída, fira aquele mínimo 
justiça, enquanto parâmetro de controlo da margem de livre decisão administrativa, se tenha vindo a afigurar diminuta ${ }^{30}$.

Ora, em nossa opinião, embora a redacção do art. $8 .^{\circ}$ do CPA pudesse ter sido um pouco mais esclarecida, com ela pretende-se, precisamente, dar ao princípio da justiça uma valia de aplicação autónoma. Porquanto, o entendimento que dele se extrai é o de que a justiça pressupõe actuações conformes à ideia de Direito, sendo a razoabilidade uma das suas vias de concretização, isto é, a justiça pressupõe uma compatibilidade com a ideia de Direito, afigurando-se a razoabilidade o critério que permite aferir essa compatibilidade, aspecto que será relevante tanto ao nível das actuações que envolvam "valorações próprias do exercício da função administrativa", como ao nível da interpretação das normas jurídicas.

Com efeito, o art. 8. ${ }^{\circ}$ do CPA, ao dispor que "A Administração Pública deve ...rejeitar as soluções manifestamente desrazoáveis ou incompativeis com a ideia de Direito", identifica a razoabilidade com a conformidade à ideia de Direito, ou seja, identifica-a com o último reduto da juridicidade, da dignidade da pessoa humana e dos direitos fundamentais. Como tal, seguindo o entendimento de JOÃo PACHECO DE AMORIM, a "razoabilidade constitui uma cláusula geral, um crivo grosso $^{31}$ a que primeiramente deve ser submetido o exercício do poder discricionário" ${ }^{32}$, servindo para aferir os casos de manifesta, notória, clara e segura desconformidade à ideia de Direito e da justiça, isto é, os casos aberrantes, que firam "o mínimo ético de justiça que é comum da consciência humana e social”, afigurando-se, deste

ético de justiça que é património comum da consciência humana e social, isto é, em que o critério usado é manifestamente desacertado e inaceitável."

30 No sentido de que o princípio da razoabilidade tem uma utilidade bastante limitada, carlo MALINCONICO, Il principio di proporzionalità, in Autorità e consenso nell'attività amministrativa. Atti del $47^{\circ}$ Convegno di studi di scienza dell'amministrazione. Varenna, Villa Monastero, 20-22 settembre 2001, Milano, 2002, p. 69.

31 Um crivo mais grosso que o crivo da proporcionalidade.

32 Cfr. JOÃO PACHECO DE AMORIM, Os princípios gerais da atividade administrativa no projeto de revisão do Código do Procedimento Administrativo, in CJA, n. ${ }^{\circ}$ 100, p. 24; e também Pedro Costa Gonçalves, Manual de Direito Administrativo, vol. I, Coimbra, 2019, p. 414. 
modo, conexa com o senso comum e com os valores propugnados em dada comunidade

Entendida nestes termos, a razoabilidade constitui, em nossa opinião, uma primeira directriz de verificação da arbitrariedade ${ }^{33}$, revelada, já há muito tempo, pela jurisprudência administrativa, através da figura do erro manifesto de apreciação ${ }^{34 / 35}$. Como é afirmado no acórdão do Supremo Tribunal Administrativo de 11.05.2005, P. 0330/05, o "Erro grosseiro ou manifesto é um erro crasso, palmar, ostensivo, que terá necessariamente de reflectir um evidente e grave desajustamento da decisão administrativa perante a situação concreta, em termos de merecer do ordenamento jurídico uma censura particular mesmo em áreas de actuação não vinculadas." Trata-se de situações em que o critério decisório adoptado pela Administração afigura-se manifestamente desacertado e inaceitável, de modo que as actuações administrativas, ainda que praticadas no âmbito de margem de livre decisão administrativa, não podem deixar de ser controladas pelos tribunais ${ }^{36}$.

A razoabilidade, por estes motivos, não deve ser confundida com a racionalidade, pois esta exige uma "coerência lógica ou completude

33 Defendendo que a razoabilidade só exclui o que qualquer pessoa sensata não poderia tolerar e os excessos do livre arbítrio, CARLO MALINCONICO, Il principio di proporzionalità, in Autorità e consenso nell'attività amministrativa. Atti del $47^{\circ}$ Convegno di studi di scienza dell'amministrazione.Varenna,Villa Monastero, 20-22 settembre 2001, Milano, 2002, p. 69.

34 A este respeito, o acórdão do Supremo Tribunal Administrativo de 12.10.2004, P. 0138/04 refere que, estando em causa a aplicação de critérios de razoabilidade, em matéria de carácter técnico, “o controle jurisdicional deverá limitar-se às situações em que seja detectável uma situação de erro claro”.

Também Federico Fabbrini refere que o controlo relativo à figura do erro manifesto de apreciação deve ser considerado como uma forma de controlo da razoabilidade, cfr. FEDERICO FABBRINI, Reasonableness as a Test for Judicial Review of Legislation in the French Constitutional Council, in Journal of Comparative Law, 2009 , pp. 55 e 56 . O mesmo autor dá conta que o controlo pela via da figura do erro manifesto de apreciação foi paulatinamente evoluindo para um controlo de "manifesta desproporção", cfr. FEDERICO FABBRINI, Reasonableness as a Test for Judicial Review of Legislation in the French Constitutional Council, in Journal of Comparative Law, 2009, p. 57.

35 Vide o acórdão do Supremo Tribunal Administrativo de 15.03.2001, P. 044018.

36 Cfr. José Manuel Sérvulo Correia, Legalidade e Autonomia Contratual nos Contratos Administrativos, reimp., Coimbra, 2013, p. 476 e 477. 
material das decisões", no sentido de que estas não podem assentar, em termos de iter decisório, em fundamentos obscuros ou antagónicos ao fim que expressamente visam atingir ${ }^{37}$. Afigurando-se a racionalidade orientada à razão lógica ${ }^{38}$, enquanto a razoabilidade orientada ao valor, podendo uma decisão ser racional sem que seja razoável. ${ }^{39}$

Para além disso, urge ainda mencionar, a este respeito, que a operacionalidade do princípio da razoabilidade ganha relevância ao nível da margem de livre decisão administrativa e quando não estejam em causa actuações vinculadas ${ }^{40}$, porquanto, ainda que o art. $8 .^{\circ}$ do CPA, como referimos, faça menção à sua importância em matéria de interpretação nas normas jurídicas, a verdade é que, tal como resulta do acórdão do Supremo Tribunal Administrativo de 12.10.2004, P. 0138/04 e do acórdão do Tribunal Central Administrativo-Norte de 26.01.2018, P. 00357/16.1BEPRT, os juízos de razoabilidade estão pensados para o exercício de poderes discricionários. Neste sentido, MÁrio Aroso de Almeida critica a redacção do preceito, defendendo que a interpretação de normas, a que ele se refere, pressupõe também o exercício de poderes de valoração próprios da função administrativa, uma vez que, no seu entendimento, "a "interpretação das normas"... tem em vista as situações em que a Administração é chamada

37 Cfr. MASSimo LA TORRE, Sullo spirito mite delle leggi. Ragione, razionalità, ragionevolezza, Editoriale Scientifica srl gennaio 2012, Napoli, 2012, pp. 10 e segs; JOÃO PACHECO DE AMORIM, Os princípios gerais da atividade administrativa no projeto de revisão do Código do Procedimento Administrativo, in CJA, n. ${ }^{\circ} 100$, p. 24.

38 No entanto, em sentido inverso, Francesco Nicotra refere-se à utilização de juízos de censura sob o plano da lógica para aferir a razoabilidade das actuações da Administratção, cfr. FRANCESCO NICOTRA, I principi di proporzionalità e ragionevolezza dell'azione amministrativa, in federalismi.it - Rivista di diritto pubblico italiano, comunitario e comparato, n. ${ }^{\circ} 12$, giugno 2017, pp. 8, 10 e 18.

39 Sobre a distinção entre os conceitos, vide MASSIMO LA TORRE, Sullo spirito mite delle leggi. Ragione, razionalità, ragionevolezza, Editoriale Scientifica srl gennaio 2012, Napoli, 2012, pp. 70 e segs.

40 O princípio da razoabilidade foi desenvolvido nos tribunais ingleses, precisamente, para controlar o exercício dos poderes discricionários públicos, cfr. FEDERICO FABBRINI, Reasonableness as a Test for Judicial Review of Legislation in the French Constitutional Council, in Journal of Comparative Law, 2009, pp. 42 e segs 
a proceder à densificação de conceitos normativos indeterminados carecidos de preenchimento valorativo, em que não the cabe realizar uma operação verificativa de mera subsunção lógica, mas uma operação de concretização da norma no caso concreto, que depende de avaliações próprias, com conteúdo reconstrutivo e criativo, de criação concretizadora ou densificadora da norma, pelo que envolve momentos de escolha do interprete - aplicador.» ${ }^{41}$. Não obstante, tendo em conta a letra da lei, PEDRO Costa GonçALVES considera que o princípio da razoabilidade opera também face a normas vinculativas para evitar interpretações manifestamente desrazoáveis $^{42}$ e, da mesma forma, no acórdão do Supremo Tribunal Administrativo de 25.06.2008, P. 0291/08, invocou-se o princípio da justiça para limitar a interpretação de poderes vinculados: "Esta é uma situação em que o exercício de um poder vinculado (correç̧ão da matéria colectável em face de uma violação do princípio da especialização dos exercícios) conduz a uma situação flagrantemente injusta e em que, por isso, se coloca a questão de fazer operar o princípio da justiça, consagrado nos artigos $266 .^{\circ}, n .^{\circ} 2$, da Constituição, e 50. da Lei Geral Tributária, para obstar à possibilidade de efectuar a referida correcção... Entre esses dois valores, designadamente nos casos em que a administração fiscal não teve qualquer prejuízo com o erro praticado pelo contribuinte, deve optar-se por não efectuar a correç̧ão, limitando aquele dever de correcção por força do princípio da justiça.".

\section{C) O entendimento do princípio da razoabilidade pela jurisprudência}

O princípio da razoabilidade, no sentido da aproximação ao erro manifesto de apreciação, constitui, como referimos, uma figura já há muito tempo tratada na nossa jurisprudência administrativa, quando os tribunais anulam actos administrativos discricionários com base

41 Cfr. Mário Aroso de Almeida, O Princípio da Razoabilidade como Parâmetro de Atuação e Controlo da Administração Pública, Coimbra, 2020, pp. 40 e 41.

42 Assim, vide, Pedro Costa Gonçalves, Manual de Direito Administrativo, vol. I, Coimbra, 2019, pp. 415 e 416. 
na avaliação ou qualificação errónea da situação de facto considera$\mathrm{da}^{43 / 44}$. Trata-se de uma primeira via de controlo da margem de livre decisão quando a Administração faça uma qualificação de tal forma grosseira da realidade de facto, que não deixe quaisquer dúvidas ao juiz de que tal conduta não se pode considerar coberta por essa margem de livre decisão, nem ser imune ao controlo jurisdicional. ${ }^{45}$

A expressa invocação do princípio da razoabilidade, tal como previsto no actual art. $8 .^{\circ}$ do CPA, surge em alguns acórdãos dos tribunais administrativos, como sucede com o acórdão do Supremo Tribunal Administrativo de 29.09.2016, P. 0978/16, que liga o princípio da razoabilidade à equidade, e com o acórdão do Tribunal Central Administrativo-Norte de 26.01.2018, 00357/16.1BEPRT. No entanto, tal ocorre sem que se faça uma efectiva densificação do seu sentido.

Curiosamente, é o Supremo Tribunal de Justiça (STJ), no acórdão de 20.02.2019, P. 42/18.0YFLSB, que se debruça com maior acuidade sobre este princípio, a propósito de uma deliberação do Conselho Superior da Magistratura, acerca da classificação de um juiz (como medíocre), para a qual este tribunal é competente. Tendo o recorrente considerado que a deliberação impugnada "é inválida por ofender os princípios da legalidade, da justiça, da razoabilidade e da proporcionalidade, isto pelo facto de ser impeditiva do direito à defesa e contraditório e por ter atribuído uma notação indevida em face do real desempenho geral do Recorrente", o STJ, socorrendo-se da doutrina mais recente sobre o princípio da razoabilidade e da justiça, entendeu que “...como observado por Freitas do Amaral (ob. cit., p. 107), o princípio da justiça representa a última ratio da subordinação da Administração ao direito,

43 Cfr. Bernardo Diniz de Ayala, O (Défice de Controlo) Judicial da Margem de Livre Decisão Administrativa, Lisboa, 1995, p. 225.

44 Sobre o uso da figura pelo Conselho Constitucional francês, vide FEDERICO FABBRINI, Reasonableness as a Test for Judicial Review of Legislation in the French Constitutional Council, in Journal of Comparative Law, 2009, pp. 52 e segs.

45 A este respeito, José CARLOS VIEIRA DE ANDRADE entende que o erro de avaliação deve ser "claro e seguro ("clear error"), que não deixe quaisquer dúvidas ao juiz, ainda que após prova ou investigação, e não apenas um erro evidente, imediato, essencial ou "palmar", cfr. JOsÉ CARLOS VIEIRA DE ANDRADE, Lições de Direito Administrativo, $5^{\text {a }}$ ed., Coimbra, 2017, p. 63. 
ou seja, representa uma espécie de reserva ou último recurso de juridicidade (sobretudo com enfoque nas exigências inerentes à dignidade humana). Nesta medida, o princípio tem que ser visto como sendo de aplicação muito residual, só podendo ser invocado em situações extremas, ou seja, em situações em que todo o demais ordenamento jurídico não proporciona uma resposta satisfatória. E não já em situações, como é precisamente o caso, em que simplesmente se discorda dos critérios e da decisão da Administração. O que acaba de ser dito vale, em grande parte, para o princípio da razoabilidade, cuja ofensa também é invocada pelo Recorrente. Acrescente-se apenas que, como resulta do art. $8 .^{\circ}$, do CPA, não é toda a irrazoabilidade que releva, mas sim a irrazoabilidade manifesta (a que é evidente aos olhos do comum das pessoas, a que salta à vista, a que é gritante). A circunstância de se estar perante uma qualquer solução que, segundo a sensibilidade ou o juízo idiossincrático de cada um, possa acaso ser vista como não sendo a mais razoável, não implica qualquer ofensa ao princípio da razoabilidade. Sucede, porém, que a decisão impugnanda, concorde-se ou não com ela, nada contém que represente uma irrazoabilidade manifesta, gritante."

\section{D) Diferenças entre juízos de proporcionalidade e juízos de razoabilidade}

Tanto os juízos de razoabilidade, como os juízos de proporcionalidade são tributários da ideia de justiça e ambos, embora com graus diferentes, afiguram-se parâmetros de controlo da margem de livre decisão administrativa.

No entanto, há alguns aspectos que permitem distinguir os juízos de razoabilidade, tal como aqui a definimos, dos juízos de proporcionalidade, ao que não é alheio a sua origem, pois, como referimos, enquanto a razoabilidade tem uma matriz anglo-saxónica, a proporcionalidade foi desenvolvida originariamente pelos países com ordenamentos jurídicos de matriz romano-germânica, designadamente o alemão. ${ }^{46}$

46 Fazendo a distinção dos princípios com base na sua metodologia aplicativa, Katharine G. Young, Proportionality, Reasonableness, and Economic and Social Rights, in Proportionality: New Frontiers, New Challenges, forthcoming (2017), pp. 19 e segs. 
Assim, no que respeita à função, enquanto a razoabilidade pretende aferir o arbítrio estatal, limitando-se a um controlo da qualidade global dos interesses, não aprofundado ou detalhado, a proporcionalidade pretende resolver conflitos, visando um controlo mais incisivo da quantidade da medida e da intensidade do sacrifício imposto. ${ }^{47}$

Por sua vez, quanto ao conteúdo, a razoabilidade pretende avaliar apenas a congruência dos pressupostos de facto com o fim da medida, limitando-se a um teste de relevância, enquanto a proporcionalidade procede a um controlo incisivo dos motivos e resultados de certa medida, através de vários testes de adequação, necessidade e equilíbrio. ${ }^{48}$

Por fim, quanto à natureza, a razoabilidade permite um maior subjectivismo ${ }^{49}$, porque depende da concepção dos valores presente em cada comunidade num determinado momento histórico, enquanto a proporcionalidade conduz a um nível maior de objectivismo, pois contém um conjunto de critérios pré-definidos de carácter objectivo, que permitem uma maior validade no tempo e no espaço ${ }^{50}$.

${ }^{47}$ No sentido de que os juízos de proporcionalidade são uma decorrência do aperfeiçoamento da figura do erro manifesto de apreciação, a que os juízos de razoabilidade se reconduzem, e que a sua distinção assenta mais em critérios quantitativos do que qualitativos, cfr. FEDERICO FABBRINI, Reasonableness as a Test for Judicial Review of Legislation in the French Constitutional Council, in Journal of Comparative Law, 2009, p. 57.

48 Defendendo que os juízos de proporcionalidade implicam um controlo mais estrito, que envolve a realização de testes precisos relativos à relação entre os meios e os fins de certa medida, por contraposição à razoabilidade, que envolve a realização de testes gerais, GARRY DOWNES AM, Reasonableness, Proportionality and Merits Review - New South Wales Yong Lawyers Seminar Issues of Administrative Law, 28 September 2008, pp. 11 e 12.

49 Aflorando esta ideia, Katharine G. Young, Proportionality, Reasonableness, and Economic and Social Rights, in Proportionality: New Frontiers, New Challenges, forthcoming (2017), pp. 28 e 29.

50 Considerando, no entanto, que o princípio da razoabilidade é orientado por critérios de congruência lógica, uma vez que pretende avaliar as escolhas da Administração, o que é feito com base em motivações de carácter objectivo, por não implicar quaisquer avaliações sobre os interesses dos sujeitos destinatários de certa actuação, FRANCESCO NICOTRA, I principi di proporzionalità e ragionevolezza dell'azione amministrativa, in federalismi.it - Rivista di diritto pubblico italiano, comunitario e comparato, n. ${ }^{\circ}$ 12, giugno 2017, p. 18. 


\section{Considerações finais}

Aqui chegados, consideramos que os juízos de proporcionalidade e os juízos de razoabilidade, que podem ser feitos com base nos artigos $7 .^{\circ}$ e $8 .^{\circ}$ do CPA, são juízos distintos, no que diz respeito à sua função, ao seu conteúdo e à sua natureza, pois enquanto os primeiros implicam um controlo incisivo, feito através de vários testes, conduzindo a uma apreciação mais objectiva, os segundos configuram um controlo global dos interesses, através de meros testes de relevância, que conduzem a um maior subjectivismo.

Não obstante, somos de opinião que a autonomização de um princípio da razoabilidade, enquanto princípio autónomo da actividade administrativa, reveste-se de pouca utilidade ${ }^{51}$, desde logo porque, tal como previsto no art. $8 .^{\circ}$ do CPA, no sentido de primeira directriz de verificação da arbitrariedade, não serve para mais do que para dar uma valia de aplicação autónoma ao princípio da justiça. De modo que, a razoabilidade deveria ser encarada como um mero critério que permite a densificação de outros princípios da actividade administrativa, e não como um princípio autónomo da actividade administrativa em si mesmo.

51 Isto tendo em conta também que, nos países da common law, onde o princípio da razoabilidade sempre teve grande proeminência, tem-se verificado, ao longo dos anos, uma paulatina influência da metodologia da proporcionalidade sobre a metodologia da razoabilidade, aspecto que tem contribuído para uma maior garantia da protecção dos direitos dos cidadãos. Assim, vide KATHARINE G. Young, Proportionality, Reasonableness, and Economic and Social Rights, in Proportionality: New Frontiers, New Challenges, forthcoming (2017), pp. 29 e segs. 



\section{Proporcionalidade e razoabilidade na tributação por aplicação da disposição geral antiabuso}

Gustavo Gramaxo Rozeira*

1. Dispõe-se no art. $38 .^{\circ},{ }^{\circ}{ }^{\circ}$, da LGT, na redação dada pela Lei n. ${ }^{\circ}$ 32/2019, de 3 de maio que "[a]s construções ou séries de construções que, tendo sido realizadas com a finalidade principal ou uma das finalidades principais de obter uma vantagem fiscal que frustre o objeto ou a finalidade do direito fiscal aplicável, sejam realizadas com abuso das formas jurídicas ou não sejam consideradas genuínas, tendo em conta todos os factos e circunstâncias relevantes, são desconsideradas para efeitos tributários, efetuando-se a tributação de acordo com as normas aplicáveis aos negócios ou atos que correspondam à substância ou realidade económica e não se produzindo as vantagens fiscais pretendidas."

Não obstante as várias críticas que a consagração deste preceito legal mereceu por parte de alguma doutrina ${ }^{1}$, esta denominada disposição geral antiabuso estabelece entre nós um mecanismo legal anti-elisivo instrumental à realização de uma evidente opção de

* Professor Auxiliar da Faculdade de Direito e Ciência Política da Universidade Lusófona do Porto

Investigador integrado CEAD - Centro de Estudos Avançados em Direito Francisco Suárez

1 Diogo Leite de Campos / Benjamin da Silva Rodrigues / Jor ge Lopes DE SousA, Lei Geral Tributária Anotada e Comentada, 4. ${ }^{\text {e }}$ d., Encontros da Escrita, 2012, p. 301. 
política legislativa no sentido de fazer prevalecer "a ontologia dos factos económicos sobre a fenomenologia da aparência das formas jurídicas"2.

Com efeito, este art. 38. ${ }^{\circ}$ da LGT "integra-se numa certa vertente do chamado 'realismo' do Direito Fiscal"3 ao qual preside uma ideia central de tributação dos efeitos económicos dos atos e negócios jurídicos, já que "são exatamente eles que a lei pretende sujeitar a imposto"4.

Em síntese, a tributação ao abrigo da disposição geral antiabuso prevista no art. $38 .^{\circ}$, n. $^{\circ}$ 2, da LGT visa fazer prevalecer a substância sobre a forma e postula a desconsideração, no plano estritamente fiscal, das construções negociais realmente realizadas pelos sujeitos passivos e, em substituição delas, a tributação de negócios jurídicos alternativos de "efeitos económicos equivalentes."

Não se pretende, por manifesta exiguidade de espaço, fazer aqui uma análise completa do instituto da tributação por aplicação da disposição geral antiabuso, até porque há já abundante doutrina que dele se ocupa com detalhe. Esta exposição centrar-se-á num aspeto nuclear da aplicação desta norma: a operação de determinação dos atos e negócios de efeito económico equivalente à construção negocial efetivamente realizada pelos sujeitos passivos e que, em substituição desta última, será sujeita a tributação.

Há, na realização desta operação pela Administração fiscal, uma amplíssima margem de atuação que se presta facilmente a abusos e desvios e que, como se pretende demonstrar seguidamente, não pode ficar imune a uma aplicação estrita e vinculada quer do princípio da proporcionalidade, quer do princípio da razoabilidade.

2. Como se viu, para evitar a elisão fiscal o legislador estabeleceu, entre o mais, uma disposição geral antiabuso contida no art. 38. ${ }^{\circ}$, n. ${ }^{\circ}$, da LGT, através da qual o legislador teve por fito "conduzir à

2 J. Maria Fernandes Pires (coord.), Lei Geral Tributária Comentada e Anotada, Almedina, 2015, p. 322.

3 Leite de campos / Silva rodrigues / Lopes de Sousa, LGT Anotada, 2012.

4 Fernandes Pires (coord.), Lei Geral, 2015, p. 323. 
tributação determinadas realidades que, por força da distorção introduzida pelos contribuintes, produziram uma redução, eliminação ou diferimento temporal dos impostos a entregar ao Estado, se comparadas com aquelas que seriam normalmente praticadas" 5 .

Temos assim que o âmbito de aplicação da disposição geral antiabuso está circunscrito àquelas hipóteses onde exista um "indevido aproveitamento do precário corpo normativo, donde fiquem frustrados os objetivos arrecadatórios do legislador" pois a disposição geral antiabuso respeita "à atitude do sujeito passivo tributário atinente ao aproveitamento abusivo de lacunas do ordenamento jurídico-fiscal”, nela se enquadrando as atuações do sujeito passivo que se situam no campo da chamada elisão fiscal que assenta na existência de negócios que as partes pretenderam validamente realizar (e realizaram) e que apenas são ineficazes de um ponto de vista fiscal - isto é, desconsiderados fiscalmente - por contrariarem os propósitos que presidem à política legislativa em matéria fiscal.

Ou seja: a tipologia dos atos e negócios abrangidos pela disposição geral antiabuso está circunscrita àquelas construções negociais que sendo plenamente válidas perante a ordem jurídica passam por ser artificiosas e desnecessárias para a obtenção do fim extrafiscal visado pelos sujeitos negociais, só se justificando o emprego delas em face dos ganhos fiscais decorrentes da sua utilização. Para se concluir pela aplicação da disposição geral antiabuso não é suficiente "que da prática integrada de um conjunto de atos ou negócios jurídicos resulte determinada vantagem fiscal, sendo necessário comprovar que a mesma é alcançada em razão de uma pré-determinação que se encontra na génese de tais atos ou negócios jurídicos"7.

Através desta disposição pretende-se, portanto, fazer prevalecer a realidade substancial e económica subjacente aos atos e negócios praticados através de formas jurídicas gizadas e implementadas com

5 José Paulo Simões, A Cláusula Geral Anti Abuso: Problemática, Aplicação e Procedimento, Bússola Fiscal, 1, p. 206.

6 Renata Almeida Cardoso, A Cláusula Geral Anti-Abuso Qualificado à Luz da Lei Geral Tributária e da Lei Fundamental da República, in Diogo Leite Campos (coord.), Estudos de Direito Fiscal, Coimbra, Almedina, pp. 172-174.

7 José Paulo Simões, A Cláusula Geral, p. 209. 
o fito principal de reduzir ou eliminar carga fiscal que seria devida caso tivesse sido utilizada a forma jurídica normalmente adequada aos efeitos económicos e materiais cuja obtenção se visava. A disposição geral antiabuso aparece assim como ultima ratio do sistema, destinada a prevenir e dissuadir um uso da lei fiscal inadequado e contrário ao espírito que a anima.

Da aplicação da disposição geral antiabuso decorre a desconsideração no âmbito tributário das construções negociais jurídicos levadas a cabo pelo sujeito passivo, as quais são havidas, nesta sede e apenas nesta sede, como ineficazes. Em suma, esta disposição confere à Administração fiscal o poder para desconsiderar, no âmbito tributário, construções negociais lícitas, mas abusivas, realizadas pelos sujeitos passivos com o intuito de elidir a aplicação de determinada norma de incidência tributária. Porém, os negócios celebrados pelos sujeitos passivos não perdem sua validade, tornando-se ineficazes apenas no plano do ordenamento tributário como meio de sancionar fiscalmente a sua manobra astuciosa.

Há assim que ter presente que a disposição antiabuso reclama, como pressuposto essencial, que estejamos na presença de uma construção negocial plenamente válida e que as partes quiseram efetivamente realizar. A opção tomada pelos sujeitos passivos no sentido de obter a poupança fiscal deve "corresponder à efetiva vontade do indivíduo, nunca equivalendo a um ato simulado ou oculto, mas sempre real. Cumpre lembrar tratar-se de atividades válidas e lícitas, a serem admitidas de forma livre e mediante opção. Vale dizer, os atos ou negócios não são objeto de reprovação por quaisquer normas e como tais, devem ter sido eleitos voluntariamente pelo contribuinte, dentre alternativas que conduzem a um resultado fiscalmente menos oneroso",

Note-se, portanto, que a disposição geral antiabuso não se confunde com a simulação, em que as partes declaram celebrar determinado negócio, quando sob ele existe outro que foi aquele efetivamente pretenderam realizar (matéria de que trata o art. 39. ${ }^{\circ}$ da LGT). Esta figura tão-pouco se confunde com a deficiente qualificação jurídica dos factos tributários pois nestas situações haverá apenas

8 Almeida Cardoso, A Cláusula Geral, p. 181. 
que fazer a sua qualificação de acordo com a caracterização fiscal, conforme se dispõe no art. $36 .^{\circ}$, n. $^{\circ}$ 4, da LGT. A janela de aplicação da disposição antiabuso encontra-se precisamente naqueles casos em que nem a requalificação tributária nem o regime da simulação têm aplicação, pois estas disciplinas, quando possam ser aplicadas, prevalecem sobre o regime da disposição antiabuso $\left({ }^{9}\right)$ porquanto tanto no caso da realização de um negócio simulado (ou de um conjunto de negócios simulados), como no da errónea qualificação jurídica de um facto tributário se está na presença de uma conduta violadora da lei mediante a qual "é alcançada uma vantagem fiscal através de atos ilícitos. A estas hipóteses costuma-se atribuir a terminologia de evasão fiscal ou evasão fiscal stricto sensu"10.

Ou seja, no âmbito de um negócio simulado as partes não querem efetivamente o negócio que celebraram ${ }^{11}$ que se constituiu assim com base numa declaração falsa. Por seu turno, no âmbito da elisão fiscal (campo de atuação da disposição geral antiabuso) as partes de facto querem realizar o negócio em causa, ainda que por motivos distintos daqueles que normalmente presidem à vontade das partes nesse tipo negocial ${ }^{12}$. Neste caso, falsa é apenas e tão só a causa que

9 Na mesma linha de entendimento, vai a lição avisada de LEITE DE CAMPOS / Silva Rodrigues / LOPes de Sousa, LGT Anotada, 2012, p. 303: "A simulação também prevalece sobre a ineficácia dos atos previstos no artigo $38 .^{\circ}, \mathrm{n} .^{\circ} 2$, da LGT, sendo distinta deste tipo legal. Os atos elisivos são atos verdadeiros, desejados. Há unicamente uma intenção de diminuir a carga fiscal utilizando estruturas jurídicas anómalas. Anómalas, mas verdadeiras. $\mathrm{O}$ que não sucede na simulação."

10 Almeida Cardoso, A Cláusula Geral p. 174. É, porém, necessário realçar que é de ilicitude tributária de que se trata: a evasão fiscal strictu sensu não corresponde, necessariamente, ao preenchimento de qualquer tipo de ilícito (penal ou contraordenacional), cuja verificação se coloca já num outro plano, jurídico-penal, que escapa ao objeto desta exposição.

11 No negócio simulado existe uma divergência entre a vontade real e a vontade declarada, porquanto a declaração não corresponde à vontade dos sujeitos negociais, seja porque aquela inexiste em absoluto apesar da declaração produzida, seja por que o que se declarou não corresponde, parcial ou integralmente, à vontade real.

12 Cfr. Leite de Campos / Silva Rodrigues / Jorge Lopes de Sousa, LGT Anotada, 2012, p. 322. 
conduziu à celebração do negócio, pois o negócio realizado corresponde à real vontade das partes, existindo a vontade de o realizar de acordo com aquela concreta configuração e de o ver produzir os efeitos jurídicos para que tipicamente tende.

Por isso no âmbito da aplicação da disposição geral antiabuso "não há, nem poderá haver, divergência entre a vontade e a declaração"13 14 .

A existência de uma cláusula específica para a hipótese de simulação (o art. $39 .^{\circ}$ da LGT) a par de uma disposição geral antiabuso (o art. 38. ${ }^{\circ}$, n. ${ }^{\circ}$ 2, da LGT) convoca necessariamente a conclusão de que o legislador visou que a simulação fosse tratada autonomamente e não pudesse ser enquadrada e reconduzida à disposição geral antiabuso: o regime jurídico-fiscal da simulação de negócios jurídicos não é "um instrumento de combate à elisão fiscal, mas sim à evasão fiscal. (...)", porquanto a "simulação diz respeito a atos e negócios falsos (ou não queridos), enquanto a elisão (planeamento fiscal abusivo) diz respeito a operações verdadeiras. Daí, pelo menos entre nós, a inadequação da simulação para lidar com fenómenos elisivos"15.

3. $\mathrm{Na}$ esteira da doutrina que atualmente se afigura como dominante, a análise da aplicação daquela norma é decomposta em dois momentos ${ }^{16}$ : num momento, do lado da previsão normativa, a constatação de que a construção negocial efetivamente realizada pelos

13 Cfr. Gustavo Lopes Courinha, Antiabuso no Direito Tributário, Coimbra, Almedina, 2004, p. 89.

14 Nesse caso, a tributação ocorrerá já não pela aplicação da disposição geral antiabuso mas pela observância das regras respeitantes ao instituto da simulação: "a reação jurídica contra esta forma de redução abusiva do imposto a pagar pode seguir as conhecidas fórmulas civilistas: nulidade do negócio praticado e tributação do negócio simulado" (SALDANHA SANCHeS, Os Limites do Planeamento Fiscal, Coimbra, Coimbra Editora, 2006, p. 79). Ou seja: para efeitos fiscais é o negócio dissimulado que, por força da aplicação do art. 39. da LGT, deverá ser considerado para efeitos de tributação.

15 ANTÓNIO CARlos DOS SANTOS, Planeamento fiscal, evasão fiscal, elisão fiscal: o fiscalista no seu labirinto, Fiscalidade, 38, p. 83.

16 Simplificamos, neste passo, a análise da aplicação da cláusula geral antiabuso desdobrada em cinco elementos, conforme propugnado por LOPES COURINHA, A Cláusula Geral, 2004, p. 165. 
sujeitos passivos - não obstante válida e eficaz do ponto de vista do direito material - foi celebrada em abuso das formas jurídicas e com a finalidade, única ou principal, de obter uma vantagem fiscal ou de frustrar a aplicação da lei fiscal.

Num segundo momento, do lado da estatuição, a reprovação da normativo-sistemática da vantagem fiscal assim abusivamente obtida: a desconsideração, no plano do ordenamento jurídico-fiscal, dos negócios efetivamente realizados pelos sujeitos passivos e, em lugar deles, a sujeição a tributação dos negócios de efeito económico equivalente ou, nos dizeres da lei, dos "atos e negócios que correspondam à substância ou realidade económica."

É esse também o modelo analítico seguido pela generalidade da jurisprudência nas operações de sindicância da legalidade dos atos de aplicação daquele art. $38 .^{\circ}$, n. $^{\circ} 2$, da LGT $^{17}$.

O primeiro momento - traduzido na demonstração do abuso de formas jurídicas - impõe ao aplicador da disposição antiabuso a demonstração de que o conjunto de atos ou negócios jurídicos celebrados pelo sujeito passivo foi realizado com recurso a soluções jurídicas inusitadas ou improváveis com o fito de obter um ganho fiscal.

Exige-se portanto que os sujeitos passivos tenham distorcido a função social dos negócios jurídicos que implementaram, introduzindo neles cláusulas que deturpam o seu figurino legal típico ou utilizando-os em contextos desadequados à sua normal utilização no tráfego jurídico com o objetivo de obtenção de soluções fiscalmente vantajosas que sejam económica ou substancialmente equivalentes a outras soluções que, se adotadas, teriam sido sujeitas a tributação mais gravosa. A atuação da disposição antiabuso pressupõe e exige uma 'inusualidade' dos atos e negócios realizados que é demonstrativa da deturpação das funções que os negócios jurídicos foram chamados a cumprir aquando da sua regulação pelo legislador de direito material.

17 Assim, cfr. Acórdão do Tribunal Central Administrativo do Sul de 15-2-2011 (Proc. ${ }^{\circ}$ 04255/10, pesquisável em http://www.dgsi.pt); Decisão do CAAD n. ${ }^{\circ}$ 143/2014-T; Decisão do CAAD n. ${ }^{\circ}$ 208/2014-T; e Decisão do CAAD n. ${ }^{\circ}$ 377/2014-T, pesquisáveis em http://www.caad.pt. 
Feito esse diagnóstico, incumbe à Administração fiscal identificar os atos e negócios de efeito económico equivalente às operações realizadas pelos sujeitos passivos e sujeitá-los a tributação.

Recorde-se, portanto, que a aplicação do art. $38 .^{\circ}$, n. $^{\circ} 2$, da LGT não implica um juízo de invalidação ou de ineficácia dos negócios efetivamente realizados pelos sujeitos passivos: estes permanecem válidos e eficazes na ordem jurídica - os seus efeitos civis não deixam de se produzir. Porém, a consequência da aplicação da disposição antiabuso refletir-se-á no plano do ordenamento jurídico-tributário: os negócios serão desconsiderados fiscalmente, não relevando para a aplicação das leis tributárias. Em lugar deles, relevarão fiscalmente, sendo sujeitos a tributação, os negócios ou construções negociais que a Administração fiscal identificar como de efeito económico equivalente.

Trata-se, portanto, de uma operação em que a Administração é chamada a ficcionar negócios jurídicos que, em boa verdade, nunca foram celebrados para, em substituição daqueles que os sujeitos passivos realmente celebraram, os sujeitar à aplicação das normas impositivas: nessa operação intelectual cabe à Administração fiscal identificar os negócios jurídicos de efeito económico equivalente àqueles efetivamente realizados pelos sujeitos passivos e fazer incidir a tributação sobre aqueles, como se efetivamente tivessem sido realizados.

4. O poder para proceder à tributação por aplicação da disposição geral antiabuso prevista no art. $38^{\circ}, \mathrm{n} .^{\circ} 2$, da LGT compreende uma ampla margem de atuação por parte da Administração na medida em que está em causa a aplicação de um conjunto de conceitos legais indeterminados, plasmados no art. $38 .^{\circ}$, n. $^{\circ} 2$, da LGT, cujo preenchimento o legislador confiou, num primeiro momento, à Administração fiscal.

É portanto à Administração fiscal que cabe fazer uma apreciação quanto à identificação e determinação das construções negociais de efeito económico equivalente àquelas efetivamente realizadas pelos sujeitos passivos, determinando quais os negócios que efetivamente serão sujeitos a tributação. 
Tal porém não implica - nem deve ser tido como implicando - que essa atuação administrativa seja arbitrária ou mesmo discricionária.

Entre os princípios gerais de Direito Administrativo que parametrizam a atuação administrativa o princípio da proporcionalidade constitui um dos elementos estruturantes do Estado de direito assumindo aí, desde os seus primórdios, um lugar de destaque ${ }^{18} \mathrm{e}$ que "constitui, porventura, o mais apurado parâmetro de controlo da atuação administrativa ao abrigo da margem de livre decisão"19, designadamente quando esteja em causa a interpretação e aplicação de conceitos legais indeterminados porquanto "a sua interpretação e aplicação não são discricionárias e, por conseguinte, são jurisdicionalmente controláveis" ${ }^{20}$.

Como é sabido, um dos sentidos do princípio da proporcionalidade reporta-se à proibição do excesso: a proporcionalidade em sentido amplo compreende, em primeiro lugar a congruência, adequação ou idoneidade do meio ou da medida para lograr o fim legalmente proposto; em segundo lugar, engloba a proporcionalidade em sentido estrito, a já aludida proibição de excesso. Como deixou dito o Supremo Tribunal Administrativo: "a Administração está obrigada, ao atuar discricionariamente perante os particulares, a escolher de entre várias medidas que satisfazem igualmente o interesse público, a que menos gravosa se mostrar para a esfera jurídica daqueles"21. Assim, "[o] princípio da proporcionalidade, ou da proibição do excesso, constitui um limite interno da discricionariedade administrativa, que implica não estar a Administração obrigada apenas a prosseguir o interesse público - a alcançar os fins visados pelo legislador -, mas a consegui-lo pelo meio que represente um menor

18 Assim, cfr. Freitas do Amaral, Curso de Direito, cit., p.123.

19 Marcelo Rebelo de Sousa / André Salgado de Matos, Direito Administrativo Geral, tomo I, Lisboa, D. Quixote, 2004, p. 207.

20 Marcelo Rebelo De Sousa, Lições de Direito Administrativo, vol. I, Lisboa, Lex, p. 111.

21 Cfr. Acórdão do Supremo Tribunal Administrativo de 10-10-1998 (Proc. ${ }^{\circ}$ 28610, pesquisável em http://www.dgsi.pt). 
sacrifício para as posições jurídicas dos particulares"22. Em sentido estrito, também denominado como o (sub)princípio da proibição de excesso, o princípio da proporcionalidade postula "o denominado princípio da intervenção mínima, perfeitamente em consonância com o princípio de favor libertatis" ${ }^{23}$.

$\mathrm{Na}$ esteira dessa linha de pensamento, o novo Código de Procedimento Administrativo veio introduzir, no leque dos princípios gerais da atividade administrativa, a consagração expressa de um novo princípio: o princípio da razoabilidade (art. 8. $^{\circ}$ ). Nos deste preceito legal "[a] Administração Pública deve tratar de forma justa todos aqueles que com ela entrem em relação, e rejeitar as soluções manifestamente desrazoáveis ou incompatíveis com a ideia de Direito, nomeadamente em matéria de interpretação das normas jurídicas e das valorações próprias do exercício da função administrativa”.

Trata-se de um princípio que tem uma enorme afinidade com o princípio da proporcionalidade, em particular na sua dimensão de proporcionalidade em sentido estrito ${ }^{24}$. Com efeito, o princípio da proporcionalidade impõe "[q]ue a conduta [da Administração] não traduza uma desrazoável ou desequilibrada ponderação entre interesses, custos (ou inconvenientes) e beneficios (ou vantagens) dela resultantes" 25 .

Como refere SuzANa TAVARes DA Silva, "o princípio da razoabilidade assume um papel estrutural, funcionando como o elemento de conexão relevante na construção da solução jurídica mais 'acertada' quando o quadro normativo é complexo", acrescentando que "[o] que se pretende com o artigo 8. ${ }^{\circ}$ do CPA é que a Administração fundamente as suas decisões e os seus comportamentos

22 Mário esteves Oliveira / Pedro Costa Gonçalves / J. Pacheco Amorim, Código de Procedimento Administrativo Comentado, 2. ${ }^{a}$ ed., Coimbra, Almedina, 1997, p. 104.

23 José Manuel Santos Botelho / Américo Pires Esteves / José CÂnDIDO De PINHO, Código de Procedimento Administrativo Anotado - Comentado Jurisprudência, 3. ${ }^{a}$ ed., Coimbra, Almedina, 1996, p. 68.

24 Nesse sentido, cfr. FAUSTO DE QuAdros et al., Comentários à Revisão do CPA, Coimbra, Almedina, 2016, p. 36.

25 Paulo Otero, Direito do Procedimento Administrativo, I, Coimbra, Almedina, 2016, p. 177. 
em interpretações razoáveis das normas que habilitam a sua ação. Desta orientação podem resultar dois sentidos: i) A Administração está obrigada a escolher de entre as interpretações viáveis a que se apresentar mais razoável em função dos diversos fundamentos teleológicos possíveis dessa ação e ao tribunal é permitido fiscalizar a referida interpretação no sentido de apurar se é ou não a mais razoável; ii) a Administração está impedida de adotar uma interpretação desrazoável da norma habilitante e o controlo judicial há-de cingir-se a este teste de razoabilidade da interpretação adotada." ${ }^{26}$

Mais: o legislador do novo CPA associou expressamente este novo princípio da razoabilidade à ideia de Direito, impondo, dessa forma, à Administração a rejeição de soluções que sejam "incompatíveis com a ideia de Direito."

De facto, "um Estado enformado pela ideia de Direito não pode, sem negar a sua essência, ser um Estado prepotente, arbitrário ou injusto" 27. Ao impor à Administração o dever de rejeitar soluções incompatíveis com a ideia de Direito o legislador quis consagrar um "dever de rejeição de soluções contrárias ao Direito" "28, isto é, de soluções administrativas que ditem resultados proibidos ou, simplesmente, que ditem resultados não pretendidos pela ordem jurídica. Proibiu-se, por essa via, que a atuação da Administração se projete em resultados antijurídicos.

De resto, o princípio da proporcionalidade é um princípio que não é desconhecido do Direito Fiscal, porquanto ele se encontra expressamente recebido pelo art. $55 .^{\circ}$ da LGT e pelo art. $46 .^{\circ}$ do $\mathrm{CPPT}$, é certo que com particular enfoque no âmbito do procedimento tributário, mas em qualquer caso transponível para toda a atuação administrativa no domínio tributário. Com efeito, "[a] proporcionalidade não é uma mera diretriz genérica a que se encontra

26 Suzana Tavares da Silva, O Princípio da Razoabilidade, in Carla Amado GOMES et al., Comentários ao Novo Código de Procedimento Administrativo, I, 3. a ed., Lisboa, AAFDL, 2016, pp. 311-314.

${ }^{27}$ Acórdão do Tribunal Constitucional n. ${ }^{\circ}$ 16/2015, pesquisável em http://www. tribunalconstitucional.pt

28 AleXANDre SoUSA PINHeIro et al., Questões Fundamentais para a Aplicação do Código de Procedimento Administrativo, Coimbra, Almedina, 2016, p. 79. 
submetida a atividade administrativa, é um verdadeiro critério de escrutínio, de controlo, de tal atividade. A relação entre o Fisco e os contribuintes mais conforme aos valores constitucionais não se logra apenas através da legalidade, é necessária, também, a proporcionalidade; não basta uma atuação conforme com a lei, exige-se uma atuação adequada (proporcional) aos interesses em jogo" 29 .

Num domínio, como é o do art. $38 .^{\circ}$, n. $^{\circ}$ 2, da LGT, em que está em causa a interpretação e aplicação de conceitos indeterminados, com uma forte carga de incerteza jurídica, a necessidade de subordinar o direito tributário aos princípios da proporcionalidade e da razoabilidade cobra a sua maior intensidade. De facto, "mostra-se consensual na melhor doutrina que a utilização de conceitos indeterminados no direito administrativo ou no direito fiscal para balizar determinados interesses públicos e os parâmetros de avaliação pela Administração Pública, norteados por esses interesses [...] não afasta o exercício de tais poderes de avaliação, sob a forma de competência vinculada" 30 .

Como muito bem vem decidindo a jurisdição administrativa, "tratando-se de conceitos indeterminados, o processo interpretativo nem sempre é fácil e pode não levar a uma solução indubitável. Casos existirão em que não se chegará a uma única posição possível e legítima. Todavia, mesmo nesses casos, o tribunal não pode eximir-se ao dever de verificar se a solução encontrada obedeceu à melhor interpretação e preenchimento casuístico do conceito face às exigências postas pela norma em que ele se insere e aos interesses que esta visa tutelar", reforçando-se a ideia de que nos casos de preenchimento administrativo de conceitos fiscais indeterminados "o próprio processo de concretização do juízo administrativo e o os parâmetros de avaliação utilizados não são inteiramente livres, pois têm de se revelar apropriados, coerentes e razoáveis," sendo para além do mais certo que "os tribunais não podem recusar ao interessado a possibilidade de obter um controlo efetivo da aplicação,

29 Rui Duarte Morais, Manual de Procedimento e Processo Tributário, Coimbra, Almedina, 2012, p. 18.

30 Carlos Freitas Lobo, Neutralidade Fiscal das Fusões, Fiscalidade, 26/27, p. 53. 
pela administração [fiscal], de normas que contêm conceitos indeterminados [...]; nesses casos, a incidência do controle judicial há de se restringir aos limites da razoabilidade da solução escolhida" ${ }^{31}$.

5. A tributação ao abrigo da disposição geral antiabuso convoca o exercício pela Administração fiscal do poder de reconfigurar uma construção negocial lícita e efetivamente celebrada pelos sujeitos passivo num negócio ou encadeamento de negócios que, exclusivamente no plano do ordenamento jurídico-tributário, serão objeto de tributação como se tivessem sido, de facto, celebrados pelas partes.

No entanto, quando a vontade de exação da Administração fiscal pretenda considerar ineficazes no âmbito tributário negócios jurídicos - que, no plano do direito substantivo, são perfeitamente válidos e lícitos - e, em sua vez, fazer incidir a tributação sobre negócios de efeito económico equivalente, a sua atuação não é imune à parametricidade dos princípios da proporcionalidade e da razoabilidade.

Com efeito, a subordinação a estes princípios coloca-se, desde logo, na busca das soluções de equivalência de efeitos económicos - isto é, na identificação e determinação das construções negociais sobre as quais fará incidir a tributação. Pode neste passo afirmar-se que existe uma simetria metodológica na medida em que também a Administração fiscal deve pautar a sua atuação pela busca de soluções razoáveis e proporcionais que sejam respeitadoras da função social e dos figurinos legais típicos dos negócios jurídicos que ela vier a identificar como sendo de efeito legal equivalente pois nesta operação de procura de equivalência de efeitos económicos não pode ser encontrada em modelos negociais claramente desajustados face à sua disciplina legal típica.

Quando, na interpretação e aplicação de conceitos legais indeterminados (como é o caso), se colocam perante a AT várias soluções alternativas de integração da previsão legal, a Administração deve rejeitar aquelas soluções que sejam manifestamente desrazoáveis, que sejam iníquas e que ofendam o sentimento de justiça e contrariem o ordenamento jurídico como um todo.

31 Cfr. Acórdão do Supremo Tribunal Administrativo de 27-11-2013 (Proc. ${ }^{\circ}$ 01159/09, pesquisável em http://www.dgsi.pt). 
A razoabilidade encontra ressonância na ajustabilidade da decisão administrativa consoante o consenso social acerca do que é usual e sensato. A proporcionalidade revela que nem todos os meios são justificados pelos fins: os meios, quando exorbitantes, ultrapassam o limiar da proporcionalidade e da razoabilidade.

De facto, a solução propugnada pela Administração fiscal tem, também ela, de assentar no respeito pela disciplina legal típica e pela vocação habitual dos modelos negociais invocados como sendo de efeito económico equivalente às construções negociais desconsideradas no plano fiscal.

É que impende sobre a Administração fiscal, na exata e mesma medida em que impende sobre os particulares, o dever de rejeitar construções negociais abusivas, dotadas de configurações absurdas e pouco habituais que desfuncionalizem os negócios ditos 'normais'. Sob pena de se violar os limites em que a atuação da Administração se deve confinar, por força e em obediência aos princípios da razoabilidade e da proporcionalidade, a tributação ao abrigo da cláusula geral antiabuso não pode assim assentar em construções de génese administrativa que consistam na utilização abusiva (ou até fraudulenta), como negócios de efeito económico pretensamente equivalente aos negócios efetivamente celebrados pelos sujeitos passivos, de institutos de direito privado em oposição à sua disciplina legal típica ou, mesmo simplesmente, de uma forma anómala face à prática jurídica comum, com o propósito aparente de travestir a realidade das coisas com uma roupagem jurídica capaz de fazer subingressar no âmbito de incidência das normas fiscais factos que lhes são totalmente alheios.

Manifestamente: a Administração fiscal não pode procurar encontrar a equivalência de efeitos económicos em negócios que, se tivessem realmente sido realizados pelas partes teriam sido passíveis do mesmo juízo de censura ético-tributária postulado pelo art. $38 .^{\circ}$, n. ${ }^{\circ}$, da LGT.

Mais grave será quando se constate que a construção negocial gizada pela Administração fiscal em aplicação da disposição geral antiabuso, se tivesse de facto sido realizada, padeceria de vícios geradores da sua invalidade, seria física ou legalmente impossível ou, até mesmo, constituiria a prática de um ilícito criminal. 
$\mathrm{Na}$ verdade, estatui-se no art. $8 .^{\circ}$ do CPA que a Administração não apenas deve "rejeitar as soluções manifestamente desrazoáveis" como deve rejeitar as soluções "incompativeis com uma ideia de Direito."

Através da figura da compatibilidade "com uma ideia de direito", agora recebida e positivada no art. $8 .^{\circ}$ do CPA, é inequívoco que o legislador quis criar "uma reserva ou último recurso de juridicidade" 32 .

Reportando ao contexto da aplicação da disposição geral antiabuso, afigura-se como incompatível com a ideia de Direito a decisão administrativa que busca requalificar e reconfigurar num enquadramento claramente patológico um evento real lícito; que procura destruir no domínio tributário os efeitos de negócios jurídicos válidos para, em seu turno e a pretexto de se tratarem dos negócios normais de efeito económico equivalente, fazer relevar fiscalmente negócios que seriam ilícitos ou inválidos.

A aplicação do $\operatorname{art.} 38 .^{\circ}$, n. $^{\circ}$ 2, da LGT não pode assim redundar num resultado antijurídico: não pode, ela mesma, representar uma solução reprovada pelo ordenamento jurídico.

Com efeito, a tributação por aplicação da disposição geral antiabuso assenta na verificação de determinados pressupostos normativamente fixados e a falta de verificação desses pressupostos impede, naturalmente, o acionamento da norma e obsta a que, nessa situação concreta, ela possa ser convocada a produzir os efeitos a que se dirige.

Os pressupostos legalmente fixados na lei para a previsão da factispécie normativa têm de existir para a estatuição da norma possa ser desencadeada e devem mostrar-se adequados à conduta administrativa adotada $^{33}$ : sendo inadequada a atuação administrativa fica impedido o acionamento da disposição geral antiabuso.

6. Em resposta a estas reservas não é invulgar encontrar-se o argumento segundo o qual, ainda que existisse alguma ilicitude na construção negocial identificada como de efeito económico equivalente, o art. $10 .^{\circ}$ da LGT consentiria na sujeição a tributação de factos tributários, mesmo que ilícitos, desde que "esses atos preencham os pressupostos das normas de incidência aplicáveis".

32 SOUSA PINHeIro et al., Questões, 2016, p. 79.

33 Cfr., nesse sentido, Otero, Direito do Procedimento, 2016, p. 513. 
Há, no entanto, uma assinalável diferença entre factos tributários ilícitos que efetivamente ocorreram no plano da realidade dos factos - e que, portanto, sobre eles pode incidir tributação nos termos do art. $10 .^{\circ}$ da LGT - e factos tributários ficcionados pela Administração fiscal como sendo de efeito económico equivalente àqueles que na verdade se verificaram.

É que no segundo caso a ilicitude dos factos tributários não existe: ela é exclusivamente criada pela Administração fiscal na operação requalificada que propugna para, dessa forma, poder acionar o seu poder impositivo.

Se o almejado objetivo de tributar se atinge através da reconfiguração de toda a construção negocial lícita e válida, mas porventura abusiva, celebrados pelos sujeitos passivos como um conjunto de atos e negócios ilícitos estaremos perante um cenário em que é a Administração quem busca criar factos tributários ilícitos para poder exercer sobre eles o seu poder impositivo.

Também sob esta perspetiva não se poderia deixar de concluir que um tal modo enviesado e rebuscado de decidir seria, sem dúvida, violador dos princípios da proporcionalidade e da razoabilidade. Não se questiona que, entre nós, os factos tributário ilícitos podem ser sujeitos a tributação. O que se questiona é, outrossim, que para conseguir tributar a Administração fiscal procure, ao abrigo dos poderes que a norma de tributação antiabuso lhe atribui, reconfigurar e requalificar uma construção negocial real e lícita num facto tributário que, além de ficcionado, seria ilícito sob o pretexto de que constituiriam os negócios 'normais' de efeito económico equivalente.

7. Não é também invulgar depararmo-nos com a tentação de emprego da disposição geral antiabuso como instrumento de correção de soluções legislativas menos bem conseguidas, como que substituindo à vontade do legislador a vontade da Administração fiscal.

Em Direito Fiscal é vulgar o legislador assumir pretensões de igualdade de tratamento de realidades que são, em substância, análogas. Esse esforço do legislador na implementação de soluções neutrais por vezes é traído, deliberadamente ou por acidente de percurso, por previsões normativas que tributam assimetricamente realidades para 
as quais se exigiria uma tendencial igualdade de tratamento. Quando assim sucede, não é cabível o apelo à disposição geral antiabuso para suprir as falhas deliberadas ou negligentes de um legislador desatento.

Não cabe ao aplicador administrativo da lei invocar a quebra da unidade sistemática do ordenamento jurídico-fiscal para, por meio da atuação dos poderes implicados na disposição geral antiabuso, suprir falhas promovidas ou toleradas pelo próprio legislador ${ }^{34}$ : quando o legislador fixa incompreensivelmente regimes distintos para realidades substancialmente iguais, não pode a Administração substituir-se na ponderação subjacente à conformação legislativa. Por mais incompreensível que possa ser, a opção do legislador não pode ser deturpada: optando por tratar diversamente o que não é substancialmente distinto, o legislador irá inelutavelmente induzir nos agentes económicos comportamentos ativos de procura dos figurinos legais sujeitos à menor carga fiscal. E a essa realidade não pode atalhar-se com a disposição geral antiabuso.

Não pode, por isso, a Administração fiscal, por meio da invocação da disposição geral antiabuso, procurar corrigir a quebra recaudatória de um enquadramento fiscal resultante de uma clara e expressa opção legislativa. Dito de outro modo: perante duas opções exatamente idênticas do ponto de vista da substância económica, não é passível de qualquer censura jurídico-tributária a opção do contribuinte por aquela que se revele menos onerosa do ponto de vista fiscal.

Se existir uma divergência de regimes fiscais incidentes sobre realidades que são substancialmente idênticas, o contribuinte pode dir-se-ia até, deve - valer-se dessa diferença de regimes e optar livremente pela via menos tributada. Num tal cenário, "não se poderá considerar, sem mais considerações, abusiva a opção do contribuinte pela via menos onerosa", 35 .

A disposição geral antiabuso não pode assim ser convocada para negar a produção da diversidade de efeitos fiscais pretendida - ou, simplesmente, tolerada - pelo legislador. A tentação de aplicar aquele preceito legal com o escopo procurar corrigir o legislador é um equívoco: à criação legislativa de um regime de desigualdade no

34 Nesse sentido, cfr. LOPEs COURINHA, A Cláusula Geral, 2004, p. 185.

35 Cfr. Decisão do CAAD n. ${ }^{\circ}$ 139/2013-T, pesquisável em http://www.caad.pt. 
tratamento de situações idênticas não pode a Administração fiscal ripostar responder com a criação de uma solução administrativa de outra desigualdade que 'compense' aquela.

Contrariamente àquela que tem sido a prática administrativa predominante, a disposição geral antiabuso não se destina a corrigir eventuais incoerências legislativas. Com efeito, uma interpretação da disposição geral antiabuso que admitisse o contrário estaria a reconhecer ao intérprete e aplicador desta disposição uma função jurisgénica: o intérprete não pode corrigir o legislador fiscal.

Como salienta SALDANHA SANCHES, é "necessário encontrar, no ordenamento jurídico-tributário e como condição sine qua non de aplicação da cláusula antiabuso, os sinais inequívocos de uma intenção de tributar [...], primeiro, porque a evitação fiscal abusiva não pode confundir-se com a permanente tentativa do contribuinte para reduzir a sua tributação ou para ponderar cuidadosamente planeamento fiscal não abusivo - as consequências da Lei fiscal na sua atividade empresarial ou pessoal [...], segundo, porque nesse esforço permanente para reduzir a carga fiscal podemos encontrar o aproveitamento pelo contribuinte do que podemos qualificar como omissões deliberadas - justas, ou não, é uma outra coisa - do legislador fiscal e, se isso aconteceu, não pode atribuir-se ao aplicador da lei a tarefa que cabe primariamente ao legislador" 36 .

8. Do exposto decorre, por fim, um outro importante corolário quanto aos limites dos poderes que resultam da disposição geral antiabuso para a Administração: esta disposição não pode também ser lida como a habilitação jurídica para a utilização de poderes administrativos com o fito de integrar lacunas legislativas nas normas de incidência fiscal.

$\mathrm{Na}$ verdade, com frequência a Administração pretende ver na aplicação da disposição geral antiabuso a concessão de um poder administrativo para estender analogicamente a situações ou condutas expressamente não abrangidas na factispécie das normas fiscais a estatuição impositiva que a lei expressamente prevê para certos factos tributários típicos, como se o art. $38 .^{\circ}$, n. ${ }^{\circ}$ 2, da LGT habilitasse

36 Saldanha Sanches, Os Limites, 2006, p. 180. 
a Administração fiscal a 'corrigir a mão' do legislador fiscal atalhando a situações de planeamento fiscal que o legislador não fora capaz de prevenir e antecipar mediante normas antiabuso específicas ou através das normas de incidência.

Ora, a analogia assenta na ideia de "tratamento igual de casos semelhantes" ${ }^{37}$, considerando que há analogia entre dois casos "quando neles se verifique um conflito de interesses paralelo, isomorfo ou semelhante - de modo a que o critério valorativo adotado pelo legislador para compor esse conflito de interesses num dos casos seja por igual ou maioria de razão aplicável ao outro"38.

Sucede, porém, que a integração por analogia das lacunas das normas fiscais incluídas no âmbito da reserva de lei da Assembleia da República está expressamente proibida pelo art. $11 .^{\circ}$, n..$^{\circ}$ 4, da LGT. Trata-se de uma proibição que está associada a, e decorre dos "interesses subjacentes ao princípio da igualdade: certeza e segurança"39.

Ao admitir-se a integração de lacunas das normas fiscais por via da analogia estar-se-iam entregando de bandeja ao intérprete administrativo amplos poderes jurisgénicos em matéria tributária que a Constituição quis reservar expressamente ao legislador parlamentar: "[c]omo a lei fiscal determina os elementos essenciais dos impostos, a analogia, neste âmbito, permitiria iludir a vontade do legislador" ${ }^{\prime 40}$. De resto, no seguimento da lição de CASALTA NABAIS, a proibição de integração analógica das lacunas das normas fiscais estende-se, pelas mesmas razões de proteção dos bens jurídico-constitucionais da certeza e da segurança jurídica, a qualquer outro meio de integração de lacunas ${ }^{41}$, posição que tem obtido a adesão uniforme da jurisprudência, segundo a qual "as normas de incidência dos tri-

37 José de Oliveira Ascensão, O Direito - Introdução e Teoria Geral, 10. a ed., Coimbra, Almedina, 1999, p. 445.

38 JoÃo BAPtiSta MACHADO, Introdução ao Direito e ao Discurso Legitimador, 12. ed., Coimbra, Almedina, 2000, p. 202.

39 Diogo Leite de CAmpos, Interpretação das Normas Fiscais, in Problemas Fundamentais de Direito Tributário, Lisboa, Vislis, 1999, p. 25.

40 Leite de Campos / Silva Rodrigues / Lopes de Sousa, Lei Geral, 2012, p. 122.

41 Assim, cfr. Casalta Nabais, Direito Fiscal, 3. ${ }^{a}$ ed., Coimbra, Almedina, 2005, p. 221. 
butos, bem como aquelas que concedem isenções ou exclusões de tributação, devem ser interpretadas nos seus exatos termos, sem o recurso à analogia, tornando prevalente a certeza e a segurança na sua aplicação"42.

Donde, o emprego da disposição geral antiabuso como mecanismo de integração de lacunas resultantes de normas tributárias abrangidas pela reserva de lei da Assembleia da República consubstancia uma flagrante violação da Constituição Fiscal.

Dito de outro modo: uma interpretação do art. $38 .^{\circ}$, n. ${ }^{\circ} 2$, da LGT segundo a qual por via desta norma a Administração fiscal estaria habilitada a proceder à integração de lacunas resultantes de normas tributárias incluídas no âmbito da reserva material da competência legislativa da Assembleia da República - seja por via de integração analógica, seja como um mecanismo alternativo ou subsidiário da via da integração analógica - seria materialmente inconstitucional por violação dos princípios da certeza e da segurança jurídica ínsitos no princípio do Estado de direito democrático (art. 2. ${ }^{\circ}$ da CRP), do princípio da legalidade tributária (art. $103 .^{\circ},{ }^{\circ}{ }^{\circ} 3$, da CRP) e da reserva parlamentar da competência legislativa em matéria tributária (art. 165. ${ }^{\circ},{ }^{\circ}{ }^{\circ} 1$, als. c), d) e i), da CRP).

E como tal afigura-se como incontornável que é de recusar a aplicação da disposição geral antiabuso com um tal alcance, isto é entendida como um mecanismo de integração das lacunas resultantes das normas antiabuso específicas mediante o qual as situações que, sendo análogas, não estivessem abrangidas por essas normas seriam remediadas pelo apelo à atuação deste instituto anti-elisivo.

42 Cfr. Acórdão do Tribunal Central Administrativo do Sul de 2-10-2012 (Proc. ${ }^{\circ}$ 5320/12, pesquisável em http://www.dgsi.pt); Acórdão do Tribunal Central Administrativo do Sul de 12-12-2013 (Proc. ${ }^{\circ}$ 7073/13, pesquisável em http:// www.dgsi.pt). 


\title{
Proporcionalidade e direitos humanos: TEDH e margem de apreciação
}

\author{
Paula Veiga ${ }^{1}$
}

SUMÁRIO: 1. O padrão internacional do princípio da proporcionalidade - algumas notas; 2. O princípio da proporcionalidade e a margem de apreciação no âmbito da CEDH

\section{O padrão internacional do princípio da proporcionali- dade - algumas notas}

A invocação do princípio da proporcionalidade pelo Tribunal Europeu de Direitos Humanos (adiante, TEDH) (e, em geral, embora com menor ênfase, pelos sistemas regionais de protecção de direitos humanos), muito tem contribuído para a difusão deste critério hermenêutico a nível global, ajudando-o a transpor as fronteiras do direito público interno ${ }^{2 / 3}$. O presente discurso insere-se, pois,

1 Faculdade de Direito, Universidade de Coimbra.

2 No direito internacional, a utilização do princípio da proporcionalidade é sobretudo judicial, socorrendo-se desta ferramenta não só o Tribunal Europeu de Direitos Humanos, a Corte Interamericana de Direitos Humanos e a Comissão Africana de Direitos Humanos, mas, também o Tribunal Internacional de Justiça e o Tribunal de Justiça da União Europeia.

3 O que nem sempre será isento de dificuldades. Neste sentido, afirma VitalinO CANAS que " $[\ldots]$ a pretensão universalizante, que está subjacente a algumas das efusivas sínteses inicialmente citadas, esbarra com questões pragmáticas: a propensão "camaleónica» do princípio e das suas derivações, isto é a sua capacidade de se metamorfosear e de se adaptar - mantendo eventualmente a estrutura 
no quadro da mútua influência entre o Direito Constitucional e o Direito Internacional Público, e, em especial, no âmbito do relacionamento entre jurisprudências, aplicado não (como é classicamente conhecido) à gramática dos direitos fundamentais, mas à dos direitos humanos.

A principal questão sobre a qual se pretende reflectir nas linhas que se seguem é, dentro deste contexto, a da relação entre a proporcionalidade e a margem de apreciação na jurisprudência do TEDH, tentando averiguar se essas duas esferas constituirão uma equação do direito público europeu.

Como é sobejamente sabido, no Direito Constitucional - portanto, no direito interno - um dos domínios específicos em que amiúde se lança mão do princípio da proporcionalidade é o da colisão entre direitos fundamentais ${ }^{4}$. Por isso, invocar o princípio da proporcionalidade no âmbito dos direitos humanos não constitui sequer uma grande novidade em termos materiais. Mas, como se defende que as categorias dogmáticas dos direitos fundamentais e dos direitos humanos não são exactamente coincidentes ${ }^{5}$, também não deixa de ser verdade que invocar o princípio da proporcionalidade na gramática dos direitos humanos pode conter diferenças e/ ou novidades.

O padrão internacional do princípio da proporcionalidade decorre, à semelhança do que sucede no direito público interno, do princípio do Estado de direito ${ }^{6}$ e tem vindo a ser enfatizado no Direito dos Direitos Humanos, embora a consagração desse princípio não seja expressa nos principais instrumentos de protecção deste tipo

básica - aos vários ordenamentos, contextos e culturas, leva a que quando focamos aspetos específicos da teoria e da dogmática do princípio da proporcionalidade em distintos ambientes jurídicos nem sempre estejamos a falar da mesma coisa". Do autor, O princípio da proibição do excesso: em especial, na conformação e no controlo de atos legislativos, Tese de Doutoramento, polic., Universidade de Lisboa, pp. 23 e 24.

4 Cfr., artigo $18 .^{\circ},{ }^{\circ}{ }^{\circ} 2$ da CRP.

5 Neste sentido, vide J. J. Gomes Canotilho, Direito Constitucional e Teoria da

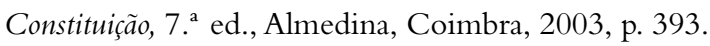

6 Há mesmo quem defenda que o princípio da proporcionalidade é uma verdadeira exigência axiológica do princípio do Estado de direito. 
de direitos. Com efeito, nem a Declaração Universal dos Direitos Humanos (adiante, DUDH), nem os Pactos (o Pacto Internacional dos Direitos Civis e Políticos (adiante, PIDCP) e o Pacto Internacional dos Direitos Económicos, Sociais e Culturais (adiante, PIDESC)) o consagram expressis verbis. A cláusula limitativa de direitos inscrita no n. ${ }^{\circ} 2$ do artigo $29 .^{\circ}$ da DUDH refere, no entanto, que o fim das limitações deve ser o de "satisfazer as justas exigências da moral, da ordem pública e do bem-estar numa sociedade democrática" e o objectivo da limitação de direitos no âmbito do artigo $4 .^{\circ}$ do PIDESC é exclusivamente o de "promover o bem-estar geral numa sociedade democrática". Já no domínio do PIDCP, a proporcionalidade não tem assumido grande relevância, questão que foi enfatizada (e criticada) pelo (então) Comité de Direitos Humanos. De qualquer modo, ao apelar para "justas exigências" há, nestes textos, uma radicação última na ideia de justiça e de balanceamento que é fundamento do princípio da proporcionalidade. A relativa juventude da Carta de Direitos Fundamentais da União Europeia poderá ser uma das razões que justifica, ao contrário do que sucede com outros instrumentos normativos, a consagração expressa do princípio da proporcionalidade no artigo $52 .^{\circ}$.

\section{O princípio da proporcionalidade e a margem de apre- ciação no âmbito da $\mathrm{CEDH}$}

No domínio da Convenção Europeia de Direitos Humanos (adiante, CEDH), o princípio da proporcionalidade vem sendo reconhecido como um princípio geral de direito, sobretudo mediante a densificaçãol jurisprudencial que o Tribunal Europeu de Direitos Humanos (adiante, TEDH) vem dando à cláusula convencional "numa

7 Dispõe assim o n. ${ }^{\circ} 1$ do artigo 52. ${ }^{\circ}$ dessa Carta: “Qualquer restrição ao exercício dos direitos e liberdades reconhecidos pela presente Carta deve ser prevista por lei e respeitar o conteúdo essencial desses direitos e liberdades. Na observância do princípio da proporcionalidade, essas restrições só podem ser introduzidas se forem necessárias e corresponderem efectivamente a objectivos de interesse geral reconhecidos pela União, ou à necessidade de protecção dos direitos e liberdades de terceiros". 
sociedade democrática". Com efeito, não sendo os direitos garantidos e protegidos pela Convenção Europeia de Direitos Humanos absolutos, as limitações emergem por via explícita (como, por exemplo, as necessárias para a "segurança nacional”, a "segurança pública", a "defesa da ordem", etc. - cfr., n..$^{\circ} 2$ dos artigos $8 .^{\circ}$ e 9. ${ }^{\circ} \mathrm{CEDH}$ ) ou por via implícita, que são definidas através da jurisprudência do Tribunal. É no que toca a este último tipo de limitações que o Tribunal tem sido, muitas vezes, chamado a analisar a proporcionalidade de uma ingerência.

Se, por definição, qualquer tratado de direitos humanos prioriza direitos, a abordagem de equilíbrio tem marcado o passo da jurisprudência do TEDH. De resto, a lógica de equilíbrio encontra-se na jurisprudência deste Tribunal quando ele equaciona entre o direito e a política, entre o comum e o individual ou entre a soberania e a internacionalização. Pode afirmar-se, pois, que o justo equilíbrio tem sido entendido como inerente ao próprio sistema da Convenção, ainda que se levantem algumas vozes discordantes, afirmando que uma retórica desta natureza (possibilitada por equação de tipo mais matemático ínsita no princípio da proporcionalidade ${ }^{8}$ ) obscurecerá considerações morais em que sempre deverá radicar a essência de um direito humano, tornando-os mais neutrais.

Parta-se, então, da noção convencional "numa sociedade democrática", inscrita nos artigos $6 .^{\circ},{ }^{\circ} .^{\circ} 1 ; 8 .^{\circ}, n .^{\circ} 2 ; 9^{\circ}, n .^{\circ} 2 ; 10 .^{\circ}, n .^{\circ} 2$; 11. ${ }^{\circ}$, n. $^{\circ} 2$ da CEDH e no artigo $2 .^{\circ}$, n. $^{\circ}$ s 3 e 4 do Protocolo n. ${ }^{\circ} 4$. É ela muitas vezes a responsável pela invocação do princípio da proporcionalidade pelo Tribunal, considerando-se, pois, a necessidade de uma restrição numa sociedade democrática uma das pedras de toque do Direito dos Direitos Humanos. Porque tal cláusula é uma condição eminentemente política, para a densificar, o TEDH tem-se socorrido amiúde da teoria da margem de apreciação, defendendo que a proporcionalidade deve ser avaliada "à luz de todas as circunstâncias",

8 Apontando a ligação entre o raciocínio matemático e o princípio da proporcionalidade, vide, inter alia, CARLOS BERNAL PULIDO, El principio de proporcionalidad $y$ los derechos fundamentales: el principio de proporcionalidad como criterio para determinar el contenido de los derechos fundamentales vinculante para el legislador, 4. ed., Universidad Externado de Colombia, Bogotá, 2014, p. 54. 
desde que: (i) o fim seja legítimo; (ii) se esteja perante valores em colisão que gozem do mesmo status convencional.

A teoria da margem de apreciação não tinha assento literal na CEDH e o seu uso pelo TEDH foi, e é, muitas vezes, criticado. A situação encontra-se hoje parcialmente resolvida, na medida em que, segundo o Protocolo n. ${ }^{\circ}$ 15, tal teoria passa a constar do Preâmbulo da $\mathrm{CEDH}^{9}{ }^{10}$. Diz-se parcialmente porque, apesar de ter sido ratificado pelo Estado português, tal Protocolo ainda não se encontra em vigor ${ }^{11}$. A primeira invocação da margem de apreciação pelo TEDH data de 1961 (caso Lawless vs. Irlanda), só tendo vindo a ser referida pela Corte Interamericana de Direitos Humanos muitos anos depois (concretamente, em 1984 ${ }^{12}$ ). Em traços muito gerais, as principais críticas que são apontadas à margem de apreciação são as de ela constituir um aceno ao princípio da soberania dos Estados, em detrimento da efectiva protecção dos direitos humanos, e a da acentuação do relativismo/especificidade que essa margem nacional comporta, em prejuízo da universalidade de que estes direitos gozam $^{13}$. Contudo, crê-se que não se podem olvidar as vantagens

9 É o seguinte o texto: "Afirmando que, em conformidade com o princípio da subsidiariedade, incumbe em primeiro lugar às Altas Partes Contratantes assegurar os direitos e liberdades definidos nesta Convenção e nos respetivos Protocolos, e que ao fazê-lo elas gozam de uma margem de apreciação, sob a supervisão do Tribunal Europeu dos Direitos Humanos criado por esta Convenção" (itálico aditado).

10 Uma das ideias fundamentais que parece resultar deste Protocolo é a da insistência no princípio da subsidiariedade, segundo o qual incumbe em primeira linha aos Estados assegurar os direitos e liberdades protegidos pela Convenção. Neste sentido, os Estados gozam de uma margem de apreciação, embora, sempre, sob a supervisão do TEDH.

11 O Protocolo n. ${ }^{\circ} 15$ foi aberto à assinatura em Estrasburgo a 24 de Junho de 2013. Foi aprovado para ratificação, por Portugal, pela Resolução da Assembleia da República n. ${ }^{\circ}$ 231/2016 e ratificado pelo Decreto do Presidente da República n. ${ }^{\circ}$ 101/2016, publicados no Diário da República, 1. ${ }^{a}$ série, n. ${ }^{\circ} 227$, de 25 de Novembro de 2016. O respectivo instrumento de ratificação foi depositado junto do Secretário-Geral do Conselho da Europa a 16 de Janeiro de 2017.

12 Opinião Consultiva 4/84, de 19 de Janeiro de 1984 (num processo sobre naturalização interposto pela Costa Rica).

13 Equacionando a margem de apreciação em interrogações, pode-se sempre perguntar: como assegurar o universalismo dos direitos humanos se, por meio da 
de a margem de apreciação permitir a protecção de direitos num espaço que é multicultural, sendo o multiculturalismo um dos valores protegidos por instrumentos de direitos humanos ${ }^{14}$, e de expressar a sensibilidade do TEDH face aos Estados no que toca a temas polémicos, o que evita tensões entre as ordens jurídicas internas e a internacional. Com efeito, na integração teleológica e dinâmica de categorias convencionais como necessidade numa sociedade democrática ou proporcionalidade da restrição relativamente à finalidade existe sempre álea na interpretação, o que comporta o risco de desarmonia entre o direito europeu e o direito interno. Ora, o resultado prático pode ser um resultado concreto divergente. Prefere-se, pois, entender, e tal posição é hoje autorizada pelo aditamento efectuado através do Protocolo n. ${ }^{\circ} 15$, que a margem de apreciação é um critério hermenêutico jurisprudencial, destinado a evitar tensões e a possibilitar o diálogo entre as jurisdições, embora a interpretação, em cada concreto, tenha sempre que se fazer ainda dentro da esfera de protecção dos direitos humanos.

Acresce que não se pode olvidar que a par de possibilitar especial sensibilidade em temas controversos, a noção de margem de apreciação não tem sido entendida, pelo TEDH, de forma estanque. Exemplo disso é a alteração da jurisprudência do TEDH nos domínios da transsexualidade e dos partidos políticos. Com efeito, se até 2002, o Tribunal sustentou que relativamente a direitos de cidadãos transsexuais não havia uma abordagem unívoca na Europa, no caso Goodwin e I vs. Reino Unido (2002), o TEDH decidiu, de forma unânime, a favor dos requerentes e alegou que existem "tendências internacionais de aceitação social dos transexuais", bem como do "reconhecimento legal de uma nova identidade sexual após a operação de mudança de sexo". O relativismo temporal inerente à margem de apreciação nota-se, outrossim, na matéria de dissolução de partidos políticos. Nesta sede, se até 2003, a margem de apreciação era extensa, no caso Partido Refah vs. Turquia (2003),

margem de apreciação, cada Estado insiste em manter sua especificidade? Será que esta teoria reforça a ideia da fraca obrigatoriedade das normas de direito internacional e, consequentemente, das normas de direitos humanos?

14 Neste sentido vide, nomeadamente, art. 27. ${ }^{\circ}$ do PIDCP. 
o Tribunal veio afirmar que os Estados detêm apenas uma margem de apreciação muito reduzida (vide $\ 100$ ), em virtude da função dos partidos no quadro da democracia e do que é necessário "numa sociedade democrática".

Atendendo ao modo como o TEDH tem recorrido à margem de apreciação, pode fazer-se a seguinte metódica de ordenação (tendencial) consoante a "natureza do direito" e o "tipo de caso": há direitos absolutos (direito à vida e proibição da tortura), há direitos fortes (direito a um julgamento justo e direitos de liberdade), há direitos qualificados (direito à privacidade e liberdades de religião, associação, expressão e não discriminação) e há direitos fracos (propriedade, educação e direito a eleições livres).

Como já se disse, segundo o TEDH, o princípio da proporcionalidade incorpora padrões fundamentais de racionalidade, constituindo um poderoso instrumento hermenêutico para se avaliar da possibilidade de uma restrição (nunca se pode olvidar que este princípio teve o seu berço em preocupações relacionadas com a contenção do poder punitivo sobre o sujeito), considerando que se deve ter também em conta a margem de apreciação de que o Estado dispõe e cuja extensão variará, sensivelmente, segundo as circunstâncias, a natureza do direito protegido e a da ingerência ${ }^{15}$. No essencial, a operação hermenêutica consistirá: $1 .^{\circ}$, na análise sobre a interferência no direito; 2. ${ }^{\circ}$, na ponderação sobre a legitimidade do fim; $3 .^{\circ}$, na análise da legalidade da restrição no âmbito do direito interno (o que revela, na prática, o princípio do primado do Direito no âmbito do sistema

15 A título exemplificativo, veja-se o caso Stoll vs. Suiç̧a, $\ 105$ (2007): “Tratando-se de liberdade de imprensa, as autoridades têm uma margem de apreciação limitada para decidir se existe um "pressing social need" " ou o caso Demir e Baykara vs. Turquia, \119 (2008): “Quanto à necessidade de tal interferência numa sociedade democrática, o Tribunal reitera que podem ser impostas restrições legais ao exercício de direitos sindicais por membros das forças armadas. No entanto, é necessário lembrar que as excepções previstas no artigo $11 .^{\circ}$ [liberdade de reunião e de associação] devem ser interpretadas restritivamente; somente razões convincentes podem justificar restrições [...]. Ao determinar se nesses casos existe uma «necessidade» - e, portanto, um «pressing social need» - na acepção do artigo $11 .^{\circ}, \$ 2$, os Estados têm apenas uma margem de apreciação limitada, que é acompanhada de uma rigorosa supervisão europeia $[\ldots]$ ”. 
da Convenção) e $4 .^{\circ}$, na análise da proporcionalidade da medida. É, justamente, nesta fase que o Tribunal poderá fazer uso da margem de apreciação, o que leva a questionar se não haverá uma intrínseca ligação conceitual entre os dois conceitos no âmbito do sistema da Convenção. Efectivamente, na operação hermenêutica parece resultar que os princípios da proporcionalidade e da subsidiariedade são imanentes à noção de margem (nacional) de apreciação, pois se houver excesso por parte de um Estado, poderá haver violação do princípio da proporcionalidade, abrindo-se espaço, por força do princípio da subsidiariedade, para a intervenção do órgão jurisdicional europeu. É essa a razão para se ter questionado logo no início se estes dois conceitos - proporcionalidade e margem de apreciação - não serão uma equação do direito público europeu. A resposta tende a ser afirmativa, não obstante o significado próprio de cada um deles. 


\title{
Juízos de proporcionalidade - em Direito Internacional ${ }^{1}$
}

\author{
Armando Rocha
}

1. O princípio jurídico da proporcionalidade é comummente reconhecido pelas ordens jurídicas constitucionais como um critério normativo de valoração da atuação pública, exigindo, grosso modo, que a conduta pública seja racional e razoável, de forma a impedir uma lesão indevida dos direitos e interesses legalmente protegidos dos indivíduos. De modo a permitir este juízo, o princípio da proporcionalidade é usualmente decomposto nas dimensões de adequação, necessidade e proporcionalidade stricto sensu - dimensões relacionais e ancoradas em juízos abstratos e, no caso da proporcionalidade stricto sensu, com elementos subjetivos de valoração axiológica.

No direito internacional público, o princípio da proporcionalidade tem sido igualmente reconhecido como elemento central desta ordem jurídica. Com efeito, sendo um conceito geral de Direito (e não um princípio específico de uma ordem jurídica interna concreta), o princípio da proporcionalidade é passível de ser universalizado e aplicado plenamente no contexto jus-internacional. Aliás, a origem monista comum do direito internacional e dos diferentes direitos internos (ainda enquanto jus gentium) explica a facilidade

1 Este texto foi preparado como suporte para a intervenção oral no XIII Encontro de Professores de Direito Público, realizado em Coimbra, a 24 de janeiro de 2020. Por esta razão, há uma certa brevidade na exposição e análise jurídica que se justifica com a natureza própria da intervenção oral. 
de partilha entre as ordens jurídicas internas e internacional destes conceitos gerais e meta-positivos de Direito.

De um ponto de vista jus-positivo, a atual alínea c) do n. ${ }^{\circ} 1$ do artigo $38 .^{\circ}$ do Estatuto do Tribunal Internacional de Justiça indica que, no âmbito da sua função de composição de litígios internacionais, este órgão pode socorrer-se dos "princípios gerais de direito reconhecidos pelas nações civilizadas”. É verdade que esta norma não tem por missão identificar ou enumerar as fontes de direito (ou, com mais rigor, as fontes de obrigações) internacionais (tarefa que, aliás, é exógena à própria ordem jurídica), mas ainda assim dispõe de autoridade suficiente para identificar as normas e fontes pacificamente aceites em direito internacional, aqui incluindo os princípios gerais de direito. Uma linha muito próxima foi seguida pelo artigo 21. ${ }^{\circ}$ do Estatuto de Roma do Tribunal Penal Internacional, cuja alínea c) do $\mathrm{n} .{ }^{\mathrm{o}} 1$ se refere aos "princípios gerais de direito que o Tribunal retire do direito interno dos diferentes sistemas jurídicos".

Em ambos os casos, estas normas convencionais permitem consolidar o estatuto jus-internacional do princípio da proporcionalidade. Com efeito, de acordo com o elemento semântico destas disposições, o catálogo de princípios gerais de direito aplicáveis em direito internacional deve incluir as normas jurídicas (1) não escritas, (2) de conteúdo normativo abrangente, (3) que sejam reconhecidas pelos direitos internos e (4) que sejam suscetíveis de transposição para o direito internacional. A chave para a descodificação destes princípios parece encontrar-se sobretudo nos pontos (3) e (4) agora enunciados: por um lado, verificando-se o quão "reconhecidos" são estes princípios gerais de direito; por outro lado, verificando-se se esta metamorfose é possível (i.e., se um determinado princípio geral de direito, como a proporcionalidade, pode servir de critério de solução de um caso concreto não apenas perante um litígio de direito interno, mas também de direito internacional). Ora, a generalização do reconhecimento jus-constitucional do princípio da proporcionalidade, aliada à facilidade de aplicação deste princípio na ordem jurídica internacional (comprovada pela sua afirmação nos diversos regimes jurídicos especiais de direito internacional), permitem com facilidade qualificá-lo como princípio geral de direito internacional. 
2. Porém, o processo de migração conceptual do princípio da proporcionalidade carece ainda de algumas notas.

Em primeiro lugar, para salientar que este transplante tem sido progressivamente mais fragmentado - o que quadra bem com a sua imersão numa ordem jurídica internacional que é, ela própria, geneticamente fragmentada. A verdade é que falar-se num (em "um") princípio de proporcionalidade em direito internacional é ignorar que as especificidades e desafios deste princípio no microcosmos dos direitos humanos são diferentes das especificidades e desafios que lhe são colocados no âmbito do direito mar, do uso da força ou do direito do investimento. $\mathrm{Na}$ realidade, não apenas os critérios de valoração são distintos, como a própria função da proporcionalidade em cada um destes regimes jurídicos especiais diverge, como se verá infra. Ora, não havendo prevalência de um sistema especial sobre outro, nem tampouco um denominador comum entre eles, apenas se pode extrair de todos estes domínios um princípio redutor e reduzido de proibição de desrazoabilidade - essa mesma ideia de razoabilidade que alguns direitos internos já autonomizaram como princípio jurídico.

A segunda nota refere-se a um enviesamento mental decorrente da sociologia do ensino do direito, centrada no treino e uso de instrumentos jurídicos internos que são ensinados como meta-positivos². $\mathrm{Ou}$ seja, no processo de formação de um jurista, somos expostos a conceitos jurídicos de tal forma rarefeitos num processo de abstração que intuímos que estes conceitos são susceptíveis de universalização. Por isso, quando nos referimos a "direito", "obrigação" ou "propriedade" num diálogo com um jurista de outra nacionalidade, intuímos de forma inconsciente (mas não necessariamente correta) que o interlocutor partilha exatamente o mesmo conceito que estamos a utilizar - mas nada podia estar mais longe da verdade. Os três exemplos que foram dados são paradigmáticos, pois são três casos em que a doutrina jus-internacional tem chegado a três conclusões: em primeiro lugar, que não existe um conceito jurídico comum entre as diversas ordens jurídicas e que possa ser universalizado; em segundo

2 E.g., cf. Hersch LaUterpacht, Private Law Sources and Analogies of International Law, Longmans, 1927, pp. 5 ss. 
lugar, que a própria compreensão sócio-cultural destes conceitos é demasiado heterogénea para permitir essa universalização; e, por fim, que a construção destes conceitos em cada ordem jurídica interna é o produto da necessidade de resolver problemas jurídicos específicos a cada ordem jurídica e que não são necessariamente mimetizados no direito internacional. Ora, a mesma dificuldade estrutural já foi prontamente identificada a propósito do princípio da proporcionalidade - pensado, como se referiu antes, para a contenção do poder público numa ordem jurídica integrada verticalmente, mas que é transposto para uma ordem jurídica horizontal e não integrada. Para além disso, os juízos de ponderação e de valoração que são próprios ao princípio da proporcionalidade estão impregnados de pré-compreensões culturais, extra-jurídicas, pelo que um juízo de proporcionalidade formulado por um jurista de um certo quadrante geográfico, social ou cultural pode diferir do juízo formulado por um jurista com outra origem geográfica, social ou cultural.

3. Em todo o caso, já referi que há casos em que o princípio da proporcionalidade foi desenvolvido no quadro do direito internacional, tendo em vista a realização de funções diferentes e há muito identificadas na doutrina jurídica: e.g., o controlo e limitação da margem de oportunidade do poder público; a ponderação entre direitos e liberdades conflituantes; o estabelecimento de um standard de sindicância judicial; ou a contenção e racionalização do poder judicial.

Para facilidade de exposição e de uma forma assumidamente não científica, vou agrupar a análise da proporcionalidade em quatro categorias diferentes, demonstrativas da ideia de que o recurso ao princípio da proporcionalidade em direito internacional não se reduz a uma única função - logo, não se reduz a um único juízo.

4. Um primeiro caso tem a ver com a proporcionalidade enquanto instrumento de controlo da atuação dos Estados e tem emergido em particular no quadro da proteção internacional dos direitos humanos. Esta, aliás, não é uma emergência que nos surpreenda, pois o sucesso do princípio da proporcionalidade no mercado das ideias jurídicas está intimamente ligado ao facto de ele ser um meio bastante ágil de contenção e 
sindicância do exercício da autoridade pública, sendo por isso particularmente adequado para o contexto de processos de integração vertical, no quadro de uma cultura democrática de "fundamentação" da atuação dos poderes públicos que condiciona a validade de qualquer atuação pública ao cumprimento de padrões materiais-substantivos estritos. Neste quadro, a persuasão dos destinatários da atuação pública não deriva do medo cósmico instilado pela ideia de poder ${ }^{3}$, mas antes, inter alia, da racionalidade e razoabilidade da sua atuação.

Claro está que a Convenção Europeia dos Direitos Humanos (para me socorrer de um exemplo que nos é próximo) não transforma a estrutura horizontal e não integrada do direito internacional, mas permite a um órgão judicial internacional averiguar a conformidade de uma atuação nacional com um tratado de proteção de direitos humanos - atuação nacional esta que se realiza em relações jurídicas internas, estas sim verticalmente integradas.

A título puramente ilustrativo, veja-se o caso Sejdic and Finci, no qual o Tribunal Europeu dos Direitos Humanos declarou que os direitos dos indivíduos queixosos (in casu, direitos de participação eleitoral ativa) foram infringidos pela própria Constituição da Bósnia-Herzegovina, exortando este Estado a rever o seu texto fundamental. Os factos deste caso remontam aos Acordos de Dayton (1995), que construíram um sistema político-eleitoral de compromisso entre os diferentes "povos constituintes" deste Estado (i.e., bósnios, sérvios e croatas), vedando o direito de ser eleito para alguns órgãos de soberania aos indivíduos que não pertençam a algum destes "povos constituintes". Questionado sobre se esta restrição era conforme, inter alia, com o disposto nos artigos $14 .^{\circ}$ da Convenção Europeia dos Direitos Humanos e 3. ${ }^{\circ}$ do Protocolo Adicional n. ${ }^{\circ} 1$, o Tribunal Europeu dos Direitos Humanos declarou a violação destas disposições, na medida em que o regime jurídico de acesso aos órgãos de soberania em causa "não satisfaz o requisito de proporcionalidade" ${ }^{4}$, porquanto a evolução política e social posterior aos

3 Mikhail Bakhtin, Rabelais and His World [1965], Indiana University Press, 1984, pp. 335-336.

4 Sejdić and Finci v. Bosnia and Herzegovina (Apps 27996/06 \& 34836/06), Acórdão do ECtHR de 22.12.2009, \46. 
Acordos de Dayton permitiria configurar medidas menos ablativas do direito de participação eleitoral ativa (violação da dimensão de necessidade), tornando por isso desrazoável a impossibilidade do acesso aos órgãos de soberania em causa de indivíduos que não pertençam aos "povos constituintes" (violação da dimensão de proporcionalidade stricto sensu $)^{5}$.

Por outro lado, ao abrigo da sua jurisprudência sobre obrigações positivas, este apelo pela aplicação do princípio da proporcionalidade a relações jurídicas verticais já foi transposto para o âmbito de relações jurídicas entre sujeitos privados (designadamente, relações jurídicas laborais ${ }^{6}$, com o intuito de estabelecer um critério de proporcionalidade comummente aplicado pelos diversos Estados e, destarte, contribuir para a formação da ordem pública ou constitucional europeia. Aqui, porém, o foco central já não é o controlo ou limitação do poder público do Estado em relação aos particulares, mas antes a sindicância da ponderação de valores feita pelos órgãos judiciais de um Estado em caso de colisão de direitos e liberdades fundamentais dos particulares.

Nestas situações, o princípio da proporcionalidade tem um efeito emancipador, uma vez que as ponderações de valor necessárias para se aferir do cumprimento das disposições da Convenção Europeia dos Direitos Humanos são retiradas à discricionariedade do decisor nacional. Porém, a transferência deste juízo de ponderação do espaço de diálogo nacional para o Tribunal Europeu dos Direitos Humanos levanta por si só uma questão de legitimidade para a formulação destes juízos de ponderação de valor feitos por órgãos plano supra-nacionais. No caso Sejdic and Finci, o Tribunal Europeu dos Direitos Humanos esboçou uma narrativa que lhe permitisse concluir pela desnecessidade e desrazoabilidade da norma constitucional nacional, mas a verdade é que (neste como noutros casos) dificilmente se antolha qual foi o iter cognoscitivo que conduziu o tribunal a esta conclusão. É esta a "opacidade" que tanto tem sido

5 Cf. Sejdić and Finci v. Bosnia and Herzegovina, SS 47-50.

6 Bărbulescu v. Romania (App. 61496/08), Acórdão do ECtHR de 05.09.2017, SS 121-122; López Ribalda and Others v. Spain (Apps 1874/13 \& 8567/13), Acórdão do ECtHR de 17.10.2019, SS 116-117. 
criticada em relação aos tribunais internacionais quando formulam juízos de proporcionalidade ${ }^{7}$. Em certa medida, esta dificuldade decorre diretamente do facto de o princípio da proporcionalidade incorporar necessariamente ponderações extra-jurídicas. Isto é, ainda que a valoração de proporcionalidade seja formalmente jurídica, ela comporta uma dimensão eminentemente política, colocando o juiz perigosamente perto da fronteira entre a feitura e a interpretação da norma jurídica. Assim, não obstante o princípio da proporcionalidade ser um meio de des-politizar formalmente o discurso jurídico, um juízo de ponderação de valores com base uma ideia de proporcionalidade está impregnado de considerações políticas. Esta dimensão extra-jurídica não é uma novidade trazida pelo direito internacional, mas é uma questão radicalmente problemática na ordem jurídica internacional, sobretudo em face do fenómeno "Estado pós-Constituição", ou seja, aquele em que as instituições constitucionais nacionais se revelam incapazes de pôr termo a conflitos sociais e culturais fraturantes, colocando a decisão final nas mãos de órgãos internacionais, quando o local próprio para construir uma solução consensual parece ser no plano nacional ${ }^{8}$.

Ora, a lógica de um sistema jurídico operativamente fechado, mas cognitivamente aberto, mesmo na sua versão mais liberal, dificilmente convive com a possibilidade de um princípio jurídico ter elementos não jurídicos na estrutura sua norma, pois permitir que um tribunal faça este tipo de juízos implica repensar o seu papel no sistema jurídico. Esta é uma preocupação que não é estranha a nenhum sistema de direito interno. Mas o que importa aqui não é apenas de saber o que pode fazer um juiz nacional quando tem de formular um juízo de proporcionalidade ao abrigo de uma norma jurídica internacional: é também de permitir que tribunais e órgãos internacionais (tal como, aliás, outros Estados e sujeitos de direito com capacidade jurídica internacional) possam contestar o mérito

7 Cf., e.g., KeVIN CROw, The Opacity of Proportionality in International Courts: Could Categories Clarify?, George Washington International Law Review 59, 2019.

8 Armando Rocha, Opiniões, in Paulo Pinto de Albuquerque (coord.), Comentário da Convenção Europeia dos Direitos do Homem, III, Universidade Católica Editora, 2020, p. 3191. 
das opções políticas, normativas, decisórias ou executórias de cada Estado ao abrigo dessa mesma norma internacional. O que permite, por isso, é que instâncias internacionais controlem o mérito da atuação interna com base não em juízos previsíveis e decorrentes da interpretação da Convenção Europeia dos Direitos Humanos à luz dos cânones inscritos nos artigos $31 .^{\circ}$ a $33 .^{\circ}$ da Convenção de Viena de 1969 sobre o Direito dos Tratados, mas antes com base em juízos de mérito que incorporam visões do mundo e do direito que não têm necessariamente presença explícita na norma jurídica aplicada.

5. Um segundo caso refere-se à proporcionalidade como instrumento de estabilização de expectativas: o caso da proteção internacional do investimento. Tal como no caso anterior, esta função pressupõe um modelo de integração vertical no âmbito de relações jurídicas de direito interno, designadamente porque se dirige cirurgicamente ao exercício de jurisdição prescritiva e executória por parte de cada Estado em relação à sua intervenção na economia. Nestes casos, a proporcionalidade permite respeitar a função de contenção do poder público, mas pretende sobretudo garantir um quadro regulatório bastante firme e duradouro e que, por essa razão, encoraje o investimento estrangeiro. Ou seja, enquanto no caso anterior a contenção do poder público era um fim em si mesmo, neste segundo caso a contenção do poder público pela proporcionalidade é instrumental para a realização de uma função primária do Direito enquanto sistema social: a estabilização de expetativas normativamente fundadas ${ }^{9}$.

Com efeito, frequentemente os tratados de investimento (bilaterais ou multilaterais) têm em vista encorajar o investimento externo através de duas obrigações complementares, grosso modo: (1) a proibição de os Estados de adotarem "medidas desrazoáveis e discriminatórias" que possam prejudicar o investimento estrangeiro (obrigação negativa, non facere); e (2) a obrigação de os Estados assegurarem um nível de "proteção e tratamento equitativo e razoável" do investimento estrangeiro (obrigação positiva, facere). Em ambos os casos, a palavra-chave parece ser a tal ideia de "razoabilidade"

9 Niklas Luhmann, Law as a Social System [Das Recht del Gesellschaft: 1993], Oxford University Press, 2004, pp. 142 ss. 
já autonomizada em algumas ordens jurídicas internas como um princípio jurídico autónomo.

A prática dos tribunais arbitrais de investimento parece confirmar esta ideia, ao sujeitar o exercício de poderes soberanos de um Estado a uma avaliação de razoabilidade. A título puramente ilustrativo, veja-se o caso Saluka Investments B.V.v. Czech Republic, no qual um investidor privado alegava que, no âmbito de um processo de privatização do sector bancário na República Checa, o Estado checo não respeitara o direito à proteção do seu investimento, designadamente por não lhe garantir um tratamento justo e equitativo. $\mathrm{Na}$ sua decisão, o tribunal arbitral mostrou alguma compreensão pela opção de política económica formulada pelo governo checo, mas considerou que a proteção de expetativas jurídicas do investidor privado era particularmente frustrada por uma medida nacional sem justificação razoável (violação da dimensão de proporcionalidade stricto sensu $)^{10}$. Ou seja, após uma análise do mérito da opção económica do governo checo, o tribunal arbitral considerou que o Estado não tinha dado uma explicação suficientemente forte para prevalecer sobre o bem jurídico tutelado sob a égide do "investimento privado", designadamente porque lhe faltava em absoluto uma dimensão de previsibilidade necessária à confiança nas relações jurídicas.

Reduzir a proporcionalidade a uma dimensão de razoabilidade de uma medida nacional parece equivaler a reduzi-la a um conteúdo mínimo e difícil de perscrutar. Curiosamente, é esta maior rarefação da razoabilidade que pode tornar o princípio da proporcionalidade mais intrusivo em matéria de exercício de jurisdição prescritiva e executória por parte dos Estados. Por outro lado, se o princípio da proporcionalidade tem uma componente de pré-compreensão cultural muito intensa, a avaliação do exercício de soberania por um Estado fica dependente de um diálogo entre árbitros ou juízes que não partilham necessariamente um mesmo código cultural e comunicacional. Porém, há duas notas que devem ser ressaltadas: por um lado, para referir que esta intrusão tem sido justificada com o facto de a proporcionalidade enquanto razoabilidade ter em vista

10 Saluka Investments BV v. Czech Republic (Arbitral Award) 17 March 2006, SS 327 \& 347. 
estabilizar expetativas normativamente fundadas em beneficio dos investidores privados e do tráfego jurídico em geral; por outro lado, para assinalar que a proporcionalidade enquanto razoabilidade tem sido usada para validar medidas do Estado de acolhimento que exigem maior responsabilidade às empresas investidoras, desta forma transformando a responsabilidade social da empresa numa fonte direta de obrigações jurídicas de particulares à luz do direito internacional (isto é, tornando um código ético minimalista num código jurídico).

Em todo o caso, o que parece resultar da comparação entre a jurisprudência em matéria de direitos humanos e de direito do investimento é que a funcionalização do juízo de proporcionalidade a um fim diferente (contenção do poder público vs. previsibilidade do poder público) não afeta a estrutura e decomposição do juízo de proporcionalidade (que segue os mesmos passos e é formulado vocabularmente nos mesmos termos), mas pode conduzir a soluções diferentes. Isto é, uma mesma medida nacional pode, por exemplo, sobreviver ao juízo de proporcionalidade formulado no contexto de um tratado de direitos humanos (por haver alguma racionalidade e razoabilidade na contenção do poder público), mas ainda assim ser censurada no contexto de um tratado de investimento (se lhe faltar um grau qualificado de previsibilidade).

6. Um terceiro caso refere-se à proporcionalidade como critério de restrição e controlo judicial: este é, por exemplo, o caso da delimitação de fronteiras marítimas. Não é surpresa que a proporcionalidade é amiúde referida ao longo dos diversos tratados relativos ao direito do mar (e.g., a propósito de medidas restritivas de liberdade no âmbito do exercício de jurisdição executória do Estado costeiro, tendo em vista conter o exercício do poder público e estabilizar expetativas normativamente fundadas). Porém, demonstrativa da submissão do juízo de proporcionalidade a uma função sistémica diferente é a jurisprudência em matéria de delimitação de fronteira marítima.

De forma necessariamente sucinta, esta matéria encontra-se hoje regulada pelo n. ${ }^{\circ} 1$ do artigo $74 .^{\circ}$ e pelo n. ${ }^{\circ} 1$ do artigo $83 .{ }^{\circ}$ da Convenção das Nações Unidas sobre o Direito do Mar, sendo certo que os destinatários imediatos ou diretos destas disposições 
são os Estados no exercício de uma atividade político-internacional de delimitação de fronteira marítima. Nessa qualidade, os Estados podem ajustar as suas fronteiras marítimas com um elevado grau de discricionariedade, desde que em cumprimento das normas de jus cogens e que alcancem uma solução equitativa. Todavia, quando este processo de delimitação de fronteira marítima é apresentado a um juiz ou árbitro internacional, este último não se pode substituir aos Estados na tomada de decisões político-internacionais, nem ter a mesma latitude na escolha de um método ou critério de delimitação de fronteira marítima.

Aqui entramos numa segunda nota: chegando um processo desta natureza junto de uma instância internacional, esta tem de adotar critérios objetivos e replicáveis em situações futuras, sobretudo quando decide ajustar uma linha de fronteira às características geográficas e/ou à equidade de um resultado. Ou seja, enquanto os Estados se encontram limitados apenas por valores de equidade e normas de jus cogens, os tribunais internacionais têm a necessidade de densificar critérios normativos que os guiem na tarefa decisória em processos de delimitação de fronteira marítima. Por isso, enquanto destinatárias mediatas ou indiretas do n. ${ }^{\circ} 1$ do artigo $74 .^{\circ}$ e do n. ${ }^{\circ} 1$ do artigo $83 .^{\circ}$ da Convenção das Nações Unidas sobre o Direito do Mar, as instâncias internacionais têm necessidade de dar algum conteúdo material aos critérios, métodos e finalidades do processo de delimitação de fronteira marítima, em vez de decidirem apenas de acordo com um princípio indeterminado de equidade.

Qual é, então, a função da proporcionalidade num processo em que, do ponto de vista puramente formal, as relações jurídicas são profundamente horizontais? Se no âmbito dos direitos humanos a ideia de proporcionalidade enquanto tinha em vista refrear o poder cósmico dos Estados em relação aos indivíduos; se no direito do investimento a ideia de proporcionalidade enquanto razoabilidade tinha em vista proteger o mercado contra os potenciais caprichos de um Estado soberano com amplas faculdades prescritivas, decisórias e executórias; no âmbito da delimitação de fronteiras marítimas a emergência do princípio da proporcionalidade encontra-se ligada à natureza do processo e da função judicial. Isto é, sendo a sua função dirimir litígios - mas não fazer juízos de mérito e muito menos juízos 
de soberania e jurisdição territorial -, a proporcionalidade permite, por um lado, autolimitar o poder do próprio tribunal, e, por outro lado, demonstrar aos diferentes players a objetividade e replicabilidade do processo cognitivo do tribunal. Ou seja, aqui a proporcionalidade não emerge como uma garantia da justiça, equidade ou razoabilidade da solução obtida, mas antes como um fator de previsibilidade e, por extensão, um atestado da legitimidade sociológica da solução decantada pelo tribunal.

Funcionalizado ao cumprimento deste fim, a jurisprudência internacional - seguindo o método trifásico desenvolvido pelo Tribunal Internacional de Justiça no processo Black Sea $a^{11}$ - tem usado o princípio da proporcionalidade como meio de verificação da equidade de uma solução. Isto é, para determinar o traçado concreto de uma linha de fronteira marítima, o juiz internacional começa (1) por traçar uma linha equidistante provisória, a qual é posteriormente corrigida (2) em função dos fatores preponderantes em cada caso (e.g., fatores geográficos) e (3) da possível iniquidade que resulte da desproporção entre a dimensão da linha de costa e a dimensão das áreas marítimas sob jurisdição daquele Estado ${ }^{12}$. Para este efeito, a análise feita pelo juiz internacional é reduzida ao cálculo matemático de proporção geométrica ${ }^{13}$, excluindo qualquer indagação sobre a necessidade, adequação ou proporcionalidade stricto sensu do resultado obtido. Ou seja, longe de incorporar qualquer juízo de mérito quanto a uma conduta nacional, no contexto de um processo de delimitação de fronteira marítima o juízo de proporcionalidade é reduzido a uma tarefa puramente mecânica e quantitativa da atribuição geométrica a cada Estado de áreas marítimas soberanas ou sob jurisdição como meio de avaliação da equidade da solução traçada pelo tribunal internacional. A razão de ser desta opção metodológica é fácil de compreender: mais do que procurar um conteúdo objetivo para o juízo de equidade, o juízo de proporcionalidade tem em

11 Maritime Delimitation in the Black Sea (Romania v. Ukraine) [Judgment, 3 February 2009] ICJ Rep 61.

12 Maritime, \ 122.

13 Maritime, \210-216. 
vista garantir a previsibilidade e contenção do exercício do poder jurisdicional internacional.

7. Por fim, o princípio da proporcionalidade tem sido aplicado no âmbito do uso da força ou da determinação de contramedidas como um método de cálculo de reciprocidade. Por economia de exposição, centrar-me-ei apenas no uso da força, mas chamando à atenção para o facto de que, a propósito de contramedidas, o artigo 51..$^{\circ}$ dos Draft Articles on Responsibility of States for Internationally Wrongful Acts (ILC, 2001) tem por epígrafe "proporcionalidade" e procura sujeitar a resposta de um Estado a um ato internacionalmente ilícito a um controlo quantitativo e qualitativo dos meios usados ${ }^{14}$.

Em todo caso, a referência a esta última função da proporcionalidade no contexto do uso da força é feita, permitam-me esta nota, por dever de ofício: a proporcionalidade tem sido utilizada como um método de contenção da resposta, que assim permite evitar a escalada de um conflito entre Estados; mas tem sido usada sobretudo como um álibi ou camuflagem, pretendendo justificar uma ação com a sua rotulagem como proporcional para evitar mais indagações por parte da comunidade jurídica. Ou seja, a proporcionalidade de uma medida tem sido o rótulo usado com o intuito de dispensar o escrutínio público e satisfazer, sem uma demonstração mais desenvolvida, a validade ética e jurídica de uma intervenção que, pelo contrário, é questionável em ambos os planos. O juízo de proporcionalidade surge, por isso, como um sucedâneo útil do conceito de guerra justa, ao dar relevo à contenção da conduta militar em detrimento dos danos causados pela mesma conduta - mas, na prática, o seu desiderato último não é tanto conter o dano quanto encriptar um juízo sobre uma ação militar.

Apesar desta reticência em relação ao princípio da proporcionalidade no âmbito do uso da força, a verdade é que ele tem sido aplicado tanto no denominado jus ad bellum quanto no jus in bello: no primeiro caso, como medida da resposta a um ato de agressão

14 Ainda antes deste documento, vd. Case concerning the Gabcíkovo-Nagymaros Project (Hungary v. Slovakia) [Judgment, 25 September 1997] ICJ Rep 7, \85. 
externa; no segundo caso, como medida de ponderação entre os objetivos militares e os danos infligidos.

Em relação ao jus ad bellum, apesar de a proporcionalidade parecer ser parte integrante da norma costumeira relativa ao direito de legítima defesa, o artigo 51. ${ }^{\circ}$ da Carta das Nações Unidas é omisso quanto à necessidade de uma resposta em legítima defesa se dever conter a uma medida de proporcionalidade. Porém, o Tribunal Internacional de Justiça já teve o ensejo de esclarecer, num primeiro momento, que esta disposição não afasta as exigências de necessidade e proporcionalidade stricto sensu decorrentes da norma costumeira ${ }^{15}$, bem como, num segundo momento, que as mesmas exigências de necessidade e proporcionalidade stricto sensu decorrem igualmente do artigo 51. ${ }^{\circ}$ da Carta das Nações Unidas ${ }^{16}$. Neste caso, a função da proporcionalidade (e a insistência na dissecação daquelas duas dimensões) parece ser simples: conter a resposta/defesa e, por extensão, limitar os danos potencialmente infligidos em seres humanos (civis ou militares), no meio ambiente ou em património cultural.

Por seu turno, no âmbito do jus in bello o princípio da proporcionalidade tem um papel central como critério de ponderação entre a realização de objetivos militares e a prevenção de danos infligidos nos indivíduos - cf. alínea b) do n. 5 do artigo $51 .^{\circ}$ do Protocolo Adicional n. ${ }^{\circ} 1$ às Convenções de Genebra de 12 de agosto de 1949 (1977). Neste caso, o papel do juízo de proporcionalidade é conduzir os decisores num contexto de guerra quanto à seleção, e.g., de que operações são executadas, dos alvos a serem atingidos, ou dos meios usados na execução de uma operação militar. Neste processo, parece que a decomposição e análise das três dimensões do juízo de proporcionalidade tem escassa relevância prática, sendo antes substituída por uma análise mecanizada do custo-benefício de uma operação (o que em parte se explica pelo facto de, num cenário de conflito, as decisões terem de ser tomadas de forma bastante célere, o que

15 Military and Paramilitary Activities in and against Nicaragua (Nicaragua v. United States of America) (Merits) [Judgment, 27 June 1986] ICJ Rep 14, SS 176 \& 194.

16 Legality of the Threat or Use of Nuclear Weapons [Advisory Opinion, 8 July 1996] ICJ Rep 226, \$S 41-41. 
deixa pouco espaço para a maturação própria de ponderações de valor de necessidade, adequação ou razoabilidade).

Como se vê, a emergência e centralidade do juízo de proporcionalidade tanto no jus ad bellum como no jus in bello decorre de um projeto dogmático destinado a conter o uso da força bélica dos Estados e, em particular, a conter os danos causados nos indivíduos e em bens jurídicos com valor comunitário (e.g., o meio ambiente ou o património cultural). Porém, perante a complexidade da sua aplicação prática e a escassa publicidade de cada juízo de ponderação de proporcionalidade feita pelos Estados em contextos militares, parece que este juízo de proporcionalidade se encontra largamente relegado ao autocontrolo pelos Estados. Para além disso, e regressando ao ponto central desta exposição, o juízo de proporcionalidade no contexto do jus ad bellum e do jus in bello tem uma função própria e diferente dos demais regimes especiais de direito internacional, seguindo uma matriz custo-benefício que não é comparável ao juízo de proporcionalidade efetuado no contexto dos direitos humanos, do direito do investimento ou do direito do mar (para me conter aos domínios aqui enunciados).

8. Com isto, retomo o ponto inicial desta exposição. Não é novidade que o direito internacional nasceu e se desenvolveu como uma ordem jurídica fragmentada. Desta natureza genética do direito internacional resulta que por vezes um conceito ou instituto jurídico se desenvolve de forma contida e autorreferencial no contexto de um regime jurídico especial de direito internacional - mesmo que, em todos estes domínios especiais, haja algum material genético comum a esse conceito ou instituto jurídico.

No caso do princípio da proporcionalidade, os quatro domínios selecionados não esgotam a sua aplicação no direito internacional, mas são ilustrativos, por um lado, da submissão de um juízo de proporcionalidade às necessidades próprios de cada regime jurídico especial de direito internacional (isto é, à função sistémica naquele microcosmos) e, por outro lado, do confinamento desse juízo de proporcionalidade ao regime jurídico especial de direito internacional em que foi desenvolvido (isto é, a especificidade da sua função 
sistémica parece impedir a sua migração automática para outros domínios de direito internacional).

O que então se pode questionar (seguindo o mote central deste encontro) é se em direito internacional, como no direito em geral, o princípio da proporcionalidade não esconde afinal vários juízos de proporcionalidade. E, se calhar, esta pluralidade de juízos faz parte da sua função linguística e comunicacional: simplificar a linguagem discursiva através do uso de uma expressão que é partilhada por todos os juristas e que encerra em si toda a complexidade de um problema jurídico ${ }^{17}$.

17 Vd., mutatis mutandis, Ulf LinderfalK, Towards a More Constructive Analysis of the Identity of Special Regimes in International Law - The Case of Proportionality, Cambridge International Law Journal, II, 2013, pp. 850-878. 


\title{
0 princípio da proporcionalidade e os seus críticos
}

\author{
Anabela Costa Leão*
}

SUMÁRIO: Introdução; 1. Da justiça à proporcionalidade como princípio jurídico. Estrutura e metódica de aplicação do princípio da proporcionalidade; 2. As debilidades do controlo de proporcionalidade; 3. Perspetivas para uma resposta aos críticos: a importância da análise de proporcionalidade; 4. Que balanço?

\section{Introdução}

O princípio da proporcionalidade ${ }^{1}$ conheceu grande expansão nas últimas décadas nos ordenamentos jurídicos nacionais e internacionais, estando notavelmente globalizado.

* Docente da Faculdade de Direito da Universidade do Porto e Investigadora do Centro de Investigação Jurídico-Económica da FDUP. O texto que ora se publica corresponde, com algumas alterações e desenvolvimentos, à comunicação proferida em 24 de janeiro de 2020 no painel $A$ proporcionalidade como princípio jurídico do XIII Encontro de Professores de Direito Público, acolhido pela Faculdade de Direito da Universidade de Coimbra. Agradece-se à Comissão Organizadora - à Doutora Dulce Lopes, à Doutora Catarina Santos Botelho e ao Doutor Francisco Pereira Coutinho - o amável convite para participar nos Encontros.

1 O princípio da proporcionalidade em sentido amplo proíbe o excesso, mas também o défice, ou o ficar aquém do necessário, o que se traduz respetivamente nas dimensões de Ubermassverbot e Untermassverbot, sendo neste texto 
Enquanto princípio jurídico, nasceu na Alemanha, surgindo primeiro no Direito de Polícia e expandindo-se depois a outras áreas, designadamente ao Direito Constitucional ${ }^{2}$. Cita-se a decisão do Tribunal Constitucional Federal Alemão sobre as farmácias de 1958 (Apothekenurteil, BVerfGE 7, 377, 1958) como o momento do seu nascimento no Direito Constitucional ${ }^{3}$. Expandiu-se depois a outros ordenamentos nacionais, mas também no plano internacional e supraestadual, sendo visível o seu papel na jurisprudência do Tribunal Europeu dos Direitos Humanos e na jurisprudência do Tribunal de Justiça da UE. Com efeito, como nota SCHLINK, não obstante o berço alemão, não há nada de especificamente alemão no princípio: trata-se, escreve, da resposta universal a um problema jurídico universal, que é o da limitação do poder e do controlo da arbitrariedade, conciliando a extensão da autoridade com a sua limitação ${ }^{4}$. Nada que impeça, ou que tenha impedido, portanto, a sua transferência para outros contextos ${ }^{5}$.

tomado na primeira aceção. Como escreve BERnHARD SCHLINK, Proportionality (1), in The Oxford Handbook of Comparative Constitutional Law, eds. Michel Rosenfeld e András Sajó, Oxford, Oxford University Press, 2012, pp. 718 ss., p. 727, o BVerfG vê a proporcionalidade como proteção contra o Estado, seja quando este vai demasiado longe, seja quando fica aquém ou fez muito pouco para proteger um direito ou interesse, sendo que a proibição do défice surge sobretudo em caso de conflito entre direitos. Entre nós, a proibição de proteção insuficiente foi invocada, entre outros, no Acórdão n. ${ }^{\circ}$ 75/2010 do Tribunal Constitucional (Interrupção Voluntária da Gravidez). Sobre o princípio, sua autonomia dogmática (designadamente, na relação com o princípio da proporcionalidade enquanto proibição do excesso) e relação com os deveres estaduais de proteção, $v d$. JORGE PEREIRA DA SILVA, Interdição de protecção insuficiente, proporcionalidade e conteúdo essencial, in Estudos em Homenagem ao Prof. Doutor Jorge Miranda, II, Coimbra, Coimbra Editora, 2012, pp. 185 ss.

2 Bernhard SChlink, Proportionality, pp. 728-729.

3 Assim escreve KaI MÖlleR, Proportionality: Challenging the Critics, International Journal of Constitutional Law, vol. 10, 3, 2012, pp. 709 ss., p. 709, nota 1.

4 Bernhard Schlink, Proportionality, p. 729.

5 Não obstante esta universalização do princípio da proporcionalidade, MosHE COHEn-Elyia e IDDO PORAT, Proportionality and constitutional culture, Cambridge University Press, 2013, p. 3, notam que o Direito norte-americano recorre ao "balancing" e não ao princípio da proporcionalidade enquanto tal, "balancing" este que desempenha a mesma função do que o controlo da proporcionalidade 
Mais especificamente, no que aos direitos fundamentais (que aqui usamos em sentido amplo) diz respeito, o princípio da proporcionalidade está no centro de um "modelo global de direitos", no sentido proposto por MÖLLER ${ }^{6}$. Centraremos a nossa atenção nas questões relativas a direitos fundamentais, não só, mas também por ser este o domínio por excelência de aplicação do princípio ${ }^{7}$.

A "universalização" do princípio ${ }^{8}$ fez-se e faz-se, todavia, acompanhar de diferentes conceções e metódicas de aplicação ${ }^{9}$, o que traz um outro problema: a dificuldade no recorte do princípio, tantas são as diferenças na sua realização e compreensão. $\mathrm{Ou}$, por outra, a dificuldade de separar as críticas à aplicação do princípio dos seus contextos específicos de aplicação.

Não obstante não se tratar de um princípio recente, foi, todavia, mais recentemente que começou a despertar interesse teórico e académico na teoria constitucional e dos direitos fundamentais, como nota MöLlER, seja quanto ao seu alcance e desenvolvimento, seja

e corresponde a um momento deste, o da proporcionalidade em sentido estrito. Apesar de notarem a proximidade analítica entre a proporcionalidade de base alemã e o "balancing" norte-americano, os autores mostram que são diferentes as culturas políticas e filosóficas subjacentes a ambos. Como escreve STAVROS TSAKYRAKIS, Proportionality: na assault on human rights?, International Journal of Constitutional Law, vol. 7, 3, 2009, pp. 468 ss., p. 470, nos EUA o "balancing" foi muito discutido a propósito da liberdade de expressão (1. ${ }^{a}$ Emenda), dado o confronto entre absolutistas (que entendem o direito de forma absoluta) e "balancers".

6 Desenvolvidamente, KAI MÖLLER, The global model of constitutional rights, Oxford University Press, 2012, propondo em síntese um modelo global de direitos constitucionais, assente na inflação de direitos e numa conceção ampla de direitos (prima facie), na existência de obrigações positivas e na aceitação progressiva de direitos sociais, no reconhecimento da eficácia horizontal e no uso das doutrinas do balanceamento e da proporcionalidade (pp. 22-23).

7 Bernhard Schlink, Proportionality, p. 729.

8 Nas palavras de SUZANA TAVARES DA SILVA, O tetralemma do controlo judicial da proporcionalidade no contexto da universalização do princípio: adequação, necessidade, ponderação, razoabilidade, Boletim da Faculdade de Direito da Universidade de Coimbra, LXXXVIII, 2, 2012, pp. 639 ss., p. 641, que alude a um "padrão universal de valoração de poderes e medidas" presente em todos os ordenamentos jurídicos.

9 Suzana TaVares da Silva, O tetralemma, passim, maxime pp. 641 ss. 
também numa perspetiva mais crítica, que visa evidenciar as suas limitações ${ }^{10}$, refreando o entusiasmo que o princípio suscitou.

É desse debate que se visa aqui dar alguma - necessariamente breve e incompleta - conta, em diálogo com alguns autores que se têm especificamente dedicado ao tema ${ }^{11}$. Para isso, começaremos por dar breve nota da estrutura e metódica de aplicação do princípio, identificando de seguida algumas das críticas que lhe têm sido movidas, e possíveis perspetivas de superação.

\section{Da justiça à proporcionalidade como princípio jurí- dico. Estrutura e metódica de aplicação do princípio da proporcionalidade}

\subsection{Da justiça à proporcionalidade como princípio jurídico}

Como nota SCHLINK, antes mesmo de se tornar um princípio jurídico e um princípio constitucional, já o princípio da proporcionalidade desempenhava um papel fundamental na discussão sobre a justiça ${ }^{12}$. Justiça e proporcionalidade estão relacionadas, sendo comum invocar Aristóteles e a sua conceção de justiça na Ética a Nicómaco para demonstrar isso mesmo: "o justo é o proporcional, o injusto é

10 KAI MÖLLER, Proportionality, p. 709-710. Ilustrativamente, vejam-se os vários artigos publicados no International Journal of Constitutional Law a partir de 2010 e do artigo de 2009 de STAVros TSAKYRAKIS, Proportionality: an assault on human rights? supracitado, entre os quais o de MÖLLER, que aqui se segue de perto. Para uma síntese do debate, $v d$. ainda Matthias KlatT e MORITZ MEISTER, Proportionality - a benefit to human righst? Remarks on the I.CON controversy, International Journal of Constitutional Law, vol.10, n. ${ }^{\circ}$ 3, 2012, pp. 687 ss.

11 Considerando o programa dos Encontros, questões como a aplicação do princípio em jurisdições específicas, como o Tribunal Europeu dos Direitos Humanos, ou do controlo judicial da proporcionalidade, não foram desenvolvidas.

12 Bernhard Schlink, Proportionality, p. 728. 
o que viola a proporção"13. Ou, por outra e como escreve JORGE MIRANDA, a proporcionalidade é conatural ao Direito ${ }^{14}$.

JORGE REIS NOVAIS reconhece que, tal como a proibição do arbítrio, o princípio da proporcionalidade ou da proibição do excesso é uma "componente elementar da ideia de justiça" reclamando uma "validade geral não mais confinada aos estreitos limites do Direito administrativo ou do Direito de Polícia, onde se havia anteriormente firmado" "15. Só esta vinculação entre Estado de Direito, proporcionalidade, proibição do excesso e justiça explicaria, para o autor, a sua expansão ${ }^{16}$. O princípio da proporcionalidade é, de resto, considerado uma dimensão do princípio do Estado de Direito previsto no artigo 2. ${ }^{\circ}$ da Constituição portuguesa ${ }^{17}$.

Além desta ligação, de natureza substancial, entre proporção e justiça, a própria ideia de um teste de proporcionalidade parece

13 Aristóteles apud Bernhard SCHLink, Proportionality, p. 719. Vd. ainda, inter alia, ARTHUR KAUfmann, Filosofia do Direito, Lisboa, Fundação Calouste Gulbenkian, 2009, 228 ss. Ainda que diferentes noções de justiça (liberais, socialistas, conservadoras, meritocráticas ou afirmativas, de justiça social ou de mercado livre) discordem entre si, "a justiça sempre exige que a parte que se recebe esteja em proporção com algo”, escreve SCHLINK, Proportionality, p. 719. Entre nós, sobre as diferentes conceções de justiça, vd. JOÃo CARDOSO ROSAS, Concepções de Justiça, Edições 70, 2011.

14 Jorge Miranda, Manual de Direito Constitucional, Tomo IV, Coimbra, Coimbra Editora, 2012, p. 302.

15 JORge ReIs NovaIS, Os princípios constitucionais estruturantes da República portuguesa, Coimbra, Coimbra Editora, 2004, p. 165.

16 Aharon Barak, Proportionality (2), in The Oxford Handbook of Comparative Constitutional Law, eds. Michel Rosenfeld e András Sajó, Oxford, Oxford University Press, 2012, pp. 739 ss., pp. 741-742, alude a quatro fontes jurídicas da proporcionalidade: democracia, estado de direito, a formulação das normas de direitos fundamentais como princípios e a interpretação constitucional, mesmo na ausência de referência expressa à proporcionalidade na Constituição.

$17 V d$., entre outros, J. J. Gomes Canotilho, Direito Constitucional e Teoria da Constituição, Coimbra, Almedina, 2003, pp. 243 ss. e José De Melo AleXanDRINO, Lições de Direito Constitucional, II, Lisboa, AAFDL, 2018. Sobre esta ligação na jurisprudência constitucional portuguesa, vd. PEDRO MACHETE / TERESA Violante, O princípio da proporcionalidade e da razoabilidade na jurisprudência constitucional, também em relação com a jurisprudência dos tribunais europeus, Relatório à XV Conferência Trilateral dos Tribunais Constitucionais de Espanha, Itália e Portugal, 2013, pp. 18-19. 
remeter para uma ideia de justo procedimento ou de correção interna da atuação dos poderes públicos (incluindo os poderes de controlo na sua atividade de controlo) $)^{18}$, associada ao princípio do Estado de Direito em sentido material. Numa outra aceção, a proporcionalidade expandiu-se de forma tão ampla pois é intrínseca ao que Moshe COHEN-Elyia e IDDO PORAT designam como a emergente "cultura global de justificação", baseada na noção de que o Estado deve justificar todas as suas ações ${ }^{19}$ - designadamente, quando estão em causa limitações das liberdades fundamentais.

Enquanto princípio jurídico, porém, e como se viu supra, as suas raízes são frequentemente encontradas no Direito alemão, onde surge primeiro no Direito de Polícia, expandindo-se depois a outras áreas e ao Direito Constitucional. Apesar de não esgotar aí a sua aplicação, assume protagonismo nos conflitos relativos a direitos e liberdades fundamentais, tendo por função proteger os direitos de limitações e intrusões, e encontrando nestes, para alguns, a sua específica razão de $\operatorname{ser}^{20}$ - ao ponto de algumas Constituições se lhe referirem expressa-

18 Permitimo-nos aqui evocar o conceito de moralidade interna de LON FULLER, vd. The Morality of Law, Yale University Press, 1964, em especial p. 33 ss. e, inter alia, BRIAN BIX, Natural Law Theory, in Philosophy of law, ed. Joel Feinberg e Jules Coleman, Wadsworth, 2004, p. 8 ss.

19 Moshe Cohen-Elyia e IdDo PORAt, Proportionality and constitutional culture, p. 7 e pp. 103 ss. e Is Proportionality Culturally Based? I.Connect-International Journal of Constitutional Law Blog, 28.09. 2013. Disponível em http://www. iconnectblog.com/2013/09/is-proportionality-culturally-based. Para os autores, Proportionality and constitutional culture, pp. 7-8, para esta "cultura de justificação", que se contrapõe à "cultura de autoridade" norte-americana que subjaz ao "balancing", assente na autoridade governamental para o exercício do poder, contribuíram algumas características dos sistemas constitucionais ocidentais no pós II Guerra Mundial, como uma conceção ampla de direitos, uma abordagem da interpretação constitucional que enfatiza os princípios e os valores fundamentais mais do que o texto, poucas barreiras à revisão judicial material e ausência do que designam como "buracos negros legais", ou seja, domínios em que os poderes públicos estão dispensados de apresentar uma justificação. Também sobre a cultura de justificação, KAI MÖLLER, Justifying the Culture of Justification (8 de novembro de 2018), LSE Legal Studies Working Paper $n$. o 19/2018. Disponível em https://ssrn.com/abstract=3288704.

20 Neste sentido, $v d$. Bernhard SCHLInK, Proportionality, p. 730, escreve que, na Alemanha, o princípio encontra fundamento constitucional no princípio do 
mente a propósito dos direitos fundamentais, como sucede no artigo 18. ${ }^{\circ}$ da Constituição portuguesa, que estabelece o regime da restrição de direitos, liberdades e garantias ${ }^{21}$. É, de resto, conhecida a conceção de ALEXY, segundo a qual o princípio da proporcionalidade é uma consequência de as normas de direitos fundamentais se apresentarem como princípios (tese da necessidade) ${ }^{22}$.

A conceção principiológica de direitos em geral, e a conceção principiológica de ALEXY em especial são, também elas, passíveis de críticas $^{23}$, desde logo relacionadas com o "enfraquecimento axiológico do sistema”, para usar uma expressão de VIEIRA DE ANDRADE ${ }^{24}$.

Rechtsstaat, consagrado na Constituição; porém, o facto de o princípio da proporcionalidade valer em outros sistemas jurídicos onde o respeito pelo Direito não resulta de um princípio do Rechtsstaat inscrito na constituição mostra que a sua fundação constitucional reside nos direitos e nas liberdades fundamentais.

21 Mas também noutros artigos em que estão em causa possibilidades de afetação de direitos fundamentais, como e.g. o artigo 19. (suspensão de direitos em situação de estado de exceção) ou o artigo $270 .^{\circ}$ (restrições ao exercício de direitos de militares de direitos de militares, agentes militarizados dos quadros de serviço efetivo e agentes dos serviços e forças de segurança). Acresce que o princípio da proporcionalidade releva, não apenas nas afetações de direitos liberdades e garantias, mas também de direitos sociais.

$22 V d$. ROBERT AleXY, Los derechos fundamentales y el principio de proporcionalidade, Revista Española de Derecho Constitucional, n. ${ }^{\circ}$ 91, 2011, p. 11 ss., aludindo a duas posições básicas sobre a relação entre proporcionalidade e direitos fundamentais, a tese da necessidade e a tese da contingência, a primeira sustentando que existe algum tipo de relação necessária entre direitos fundamentais e proporcionalidade, a segunda sustentando que não, pelo que a existência ou não de uma relação entre direitos fundamentais e proporcionalidade depende da opção tomada pelo direito positivo, e pronunciando-se pela primeira. Como escreve Bernhard SCHLinK, Proportionality, p. 730, para AleXY, enquanto princípios, os direitos fundamentais expressam valores e requerem a otimização dos valores que expressam, ou seja, a sua realização ao maior nível possível. $\mathrm{O}$ que, em caso de conflito, pode impor o recurso ao balanceamento. Por isso os direitos fundamentais, sendo princípios, são o fundamento constitucional do princípio da proporcionalidade.

23 Entre nós, vd. J. C.VIEIRA DE ANDRADE, Os direitos fundamentais na Constituição portuguesa de 1976, Coimbra, Almedina, 2012, p. 266 ss.

24 J. C. VIEIRA DE ANDRADE, Os direitos fundamentais na Constituição portuguesa de 1976, p. 268. Com efeito, escreve, um dos perigos das teorias "principiais" ou "principiológicas" é o do "enfraquecimento axiológico do sistema, concebendo 
Estas críticas transmitem-se, depois, ao princípio da proporcionalidade, ainda que, em rigor, sejam dele ao menos relativamente independentes (v. infra).

\subsection{Estrutura do princípio da proporcionalidade e sua metódica de aplicação}

O princípio da proporcionalidade é um teste para averiguar se uma determinada "interferência" - para o que nos interessa, no âmbito de um direito fundamental - é justificada ${ }^{25}$. Tal supõe uma relação entre os meios utilizados para atingir certos fins ou objetivos ${ }^{26}$. O princípio é suscetível de várias formulações e formas de aplicação, e mesmo a terminologia é variável. Isso torna também mais dificil a tarefa da sua análise.

Tradicionalmente, a análise de proporcionalidade é apreciada com base em três critérios ou subprincípios constitutivos ${ }^{27}$ : o princípio da adequação, nos termos do qual a medida utilizada deve ser idónea ou apropriada para atingir os fins em causa; o princípio da exigibilidade ou da necessidade, nos termos do qual a medida adotada

os direitos fundamentais como imperativos de otimização, como se não houvesse, à partida, valores intocáveis. Uma teoria normativa forte dos direitos fundamentais justifica a limitação imanente de um direito, desde que possa afirmar-se em abstrato que determinada forma aparente de exercício do direito não é, em caso algum, possível ou legítima - isto é, para usar a concetologia alexyana, onde o conteúdo do direito fundamental não é limitado por um outro princípio, mas por uma regra, em especial onde essa regra é a expressão do valor absoluto da dignidade da pessoa humana".

26 Segundo Bernhard SCHLINK, Proportionality, p.720, a estrutura do princípio da proporcionalidade não é diádica, mas triádica: não exige apenas que comparemos e.g. crime e punição, mas também que tenhamos um ponto de referência para a comparação: o tertium comparationis. Esse elemento é o fim, que é o ponto focal em relação ao qual a relação entre elementos ganha sentido. Daqui decorrem, segundo o autor, pp. 720-722, duas abordagens diferentes da análise da proporcionalidade: segundo uma delas, a estrutura triádica só se revela depois, segundo a outra a estrutura triádica é assumida ab initio.

27 Usa-se aqui a formulação adotada em AnABela Costa LeÃo, Princípio da proporcionalidade, in Ana Paula Brandão et al. (org.), Enciclopédia da União Europeia, Petrony, 2017, pp. 321 ss. 
deve revelar-se a menos onerosa de entre as medidas idóneas a atingir o fim; o princípio da proporcionalidade em sentido estrito, ou do balanceamento ou ponderação, que exige uma análise da proporcionalidade entre os custos e os benefícios resultantes da adoção da medida, não devendo a medida revelar-se "demasiado gravosa em relação à conveniência de alcançar o resultado pretendido"28.

Porém, se a proporcionalidade considera uma medida ou ação como um meio para prosseguir um fim, resta saber se a avaliação prévia do fim e, porventura, dos meios, não deverá integrar a análise de proporcionalidade, conduzindo a um controlo em quatro ou mesmo cinco tempos ou fases ${ }^{29}$. Com efeito, alega-se, caso o fim que se visa prosseguir seja ilegítimo, ou os meios utilizados "categoricamente proibidos", não fará sequer sentido proceder a um controlo da adequação, necessidade ou proporcionalidade em sentido estrito da medida ou ação ${ }^{30}$. Se uma determinada medida ou ação estiver categoricamente proibida, não poderá ser considerada um meio para atingir um fim, mesmo que possa ser adequada ou mesmo o único meio de atingir esse fim.

Assim concebida, a análise exige uma teoria dos fins e dos meios e da sua legitimidade, que não pode deixar de colocar questões ${ }^{31}$. Não é, por conseguinte, alheia a argumentos morais ${ }^{32}$ ou considerações deontológicas ${ }^{33}$, apontando-se como exemplos de fins $a b$

28 Suzana TaVAres da Silva, O tetralemma, p. 644.

29 Para Bernhard SCHLINK, Proportionality, p. 722 ss., a análise da proporcionalidade desdobra-se em cinco passos: determinação dos meios categoricamente proibidos, legitimidade do fim, adequação, necessidade e balanceamento. Já KAI MÖllER, Proportionality, p. 711 ss., propõe um desdobramento em quatro testes: objetivo legítimo, adequação, necessidade e balanceamento.

30 Bernhard SCHLINK, Proportionality, p.722-23.

$31 V d$. KAI MÖLleR, Proportionality, p. 711. Perante a possibilidade de uma leitura muito abrangente, MÖLLER. 712, propõe que nesta fase se teste a existência de "interesses que sejam candidatos a justificar a interferência no sentido de não ser totalmente implausível que estejam pelo menos racionalmente relacionados com a medida". Caso contrário, sempre claudicariam no teste da adequação ou racionalidade, escreve.

32 KAI MÖller, Proportionality, p. 712.

33 Bernhard Schlink, Proportionality, p. 722, esclarecendo que as considerações deontológicas sobre os meios categoricamente proibidos são anteriores e 
initio ilegítimos, por exemplo, o paternalismo, o proselitismo ou a discriminação ${ }^{34}$, ou como meios ab initio proscritos a tortura ${ }^{35}$. O que parece ser problemático aqui é, precisamente, esta "teoria moral da legitimidade dos fins e dos meios", ao menos se enunciada no plano abstrato, e a sua determinação em contextos pluralistas. Assim, esta legitimidade dos fins (e dos meios) terá de ser juridicamente apurada, desde logo face à constituição (a cada constituição). Ela pressupõe, naturalmente, uma tarefa de interpretação da concreta constituição ${ }^{36}$ (ou do texto que funciona como parâmetro de controlo, e.g. a Convenção Europeia de Direitos Humanos) ou, de outra perspetiva, uma tomada de posição, no que à dogmática dos direitos fundamentais diz respeito, quanto à conceção (ampla ou restrita) do âmbito de proteção dos direitos fundamentais.

Como escreve SCHLINK, por vezes a constituição densifica os fins em termos substanciais, exigindo razões específicas para a afetação de certos direitos ${ }^{37}$. Além da previsão geral do n. ${ }^{\circ} 2$ do $18 .^{\circ}$ da Constituição portuguesa, que exige que a restrição vise em geral salvaguardar outros direitos ou interesses constitucionalmente protegidos, algumas normas constitucionais estabelecem especificamente os fins que justificam a interferência nos direitos (vejam-se por exemplo o artigo $27 . .^{\circ}$ ou o artigo $\left.47 .^{\circ}\right)$. Outras vezes, da interpretação da constituição resulta a existência de "meios categoricamente

exteriores à proporcionalidade, ficando claro que a análise de proporcionalidade está condicionada pela qualidade dos direitos em causa: se estes forem "categoricamente protegidos", designadamente através de medidas categoricamente proibidas, então a análise e proporcionalidade nem sequer tem lugar: ela pura e simplesmente não faz sentido.

34 Bernhard Schlink, Proportionality, p. 723. Também Kai Möller, Proportionality, p. 712, apoiando-se em MATTIAS KUMM, exclui alguns tipos de objetivos paternalistas. Sobre paternalismo, $v d$. Benedita MAC CRORIE, Os limites da renúncia a direitos fundamentais nas relações entre particulares, Coimbra, Coimbra Editora, 2013, pp. 141 ss.

35 Bernhard Schlink, Proportionality, p. 722.

36 Bernhard Schlink, Proportionality, p. 723, escreve que a legitimidade das medidas públicas decorre da constituição e das leis e, no caso do legislador, essencialmente da constituição; para os cidadãos, a legitimidade dos fins dos cidadãos é presumida, a menos que refutada pela lei.

37 Bernhard SCHLink, Proportionality, p. 723. 
proibidos", como é o caso da proibição absoluta de recurso à tortura nos termos do $n .^{\circ} 2$ do artigo $25 .^{\circ}$, em concretização da dignidade da pessoa humana ${ }^{38}$.

Entre nós, Pedro Machete e Teresa Violante constatam que o Tribunal Constitucional seguiu desde cedo o esquema dos três testes em que se convencionou desdobrar a análise da relação entre meios e fins para efeitos de proporcionalidade, ainda que pressupondo a legitimidade constitucional desses fins e meios ${ }^{39}$, dando como exemplo disso mesmo o Acórdão n. ${ }^{\circ}$ 173/200940, no qual o Tribunal Constitucional, citando JORGE REIS NOVAIS, considerou que "a «legitimidade constitucional dos fins prosseguidos com a restrição», bem como a «legitimidade dos meios utilizados» constituem um "pressuposto lógico» da sua idoneidade"41.

Crê-se que a determinação da legitimidade, quer dos meios, quer dos fins, constitucionalmente enquadrada, é externa à proporcionalidade, limitando-a a partir de fora ${ }^{42}$. Em abstrato, parece que fará mais

38 Como escreve Pedro Garcia Marques, Anotação ao artigo 25. ${ }^{\circ}$, in Constituição Portuguesa Anotada, Tomo I, org. Jorge Miranda e Rui Medeiros, Coimbra, Wolters Kluwer/Coimbra Editora, 2010, pp. 551 ss., p. 568, “[a] proibição da tortura e dos tratos ou penas cruéis, degradantes ou desumanos constitui assim o núcleo de protecção absoluta do direito fundamental à integridade pessoal". Se proibida em todas as circunstâncias, por respeito à dignidade da pessoa humana, como sucede no n. ${ }^{\circ} 2$ do artigo $25 .^{\circ}$ da Constituição portuguesa, ela nunca poderá ser utilizada, mesmo que o recurso à tortura de um prisioneiro pudesse, por hipótese, permitir obter informações que evitariam um atentado que vitimaria centenas de pessoas. Tal implica, naturalmente, a densificação do que deva entender-se por "tortura" ou "tratamentos cruéis e degradantes".

$39 V d$. Pedro Machete / Teresa Violante, O princípio da proporcionalidade $e$ da razoabilidade na jurisprudência constitucional, pp. 18-19. Aí se escreve: "Para tanto, as atuações dos poderes públicos, justamente pelo facto de não poderem ser ilimitadas nem arbitrárias, são perspetivadas em cada caso concreto, real ou representado, como meios para atingir um certo fim, pressupondo-se naturalmente a legitimidade constitucional tanto dos primeiros como do segundo".

40 Disponível em www.tribunalconstitucional.pt.

41 Pedro Machete / Teresa Violante, O princípio da proporcionalidade e da razoabilidade na jurisprudência constitucional, p. 19.

$42 V d$., como se escreveu supra, Bernhard SCHLink, Proportionality, p. 722, esclarecendo que as considerações deontológicas sobre os meios categoricamente proibidos são anteriores e exteriores à proporcionalidade. 
sentido conceber a legitimidade do fim como um pressuposto do teste de proporcionalidade, prévio, condicionando a análise de proporcionalidade, e externo, no sentido em que a proporcionalidade se dirige à relação entre os meios e os fins. Quanto aos meios, sempre se dirá que a sua legitimidade só resulta efetivamente apurada no fim do teste de proporcionalidade, pelo que, quando muito, poderá estar em causa a determinação dos suprarreferidos "meios categoricamente proibidos" (no sentido de SCHLINK ${ }^{43}$ ), valendo em todo o caso o que se disse para o critério do fim legítimo: são pressupostos, não passos, do controlo de proporcionalidade. Não significa isto que não se exija a interpretação prévia das normas constitucionais para evitar submeter ao teste de proporcionalidade situações que são de mero conflito aparente de direitos, mas tão-só que se afigura tratar-se de uma questão estruturalmente externa ao princípio da proporcionalidade. Ainda assim, a sua consideração autónoma não é irrelevante, como veremos infra.

Os testes da adequação ou idoneidade e da necessidade são essencialmente empíricos ${ }^{44}$, ou, na terminologia de ALEXY, mandatos de otimização fáctica, que implicam um enlace entre juízo normativo e factos ${ }^{45}$. Na verdade, são menos simples do que parecem, não obstante se referirem a factos, pois, como escreve SCHLINK, suscitam questões de prova e de alocação do benefício da dúvida ${ }^{46}$.

O julgamento ou a avaliação da interferência à luz do fim ocorre, sim, na última fase, a do balanceamento ou da proporcionalidade em sentido estrito. O meio menos gravoso pode, ainda assim, ser demasiado gravoso, tendo em conta o fim que se visa atingir ${ }^{47}$. Trata-se, agora, de um momento normativo ${ }^{48}$ ou, na terminologia de AlEXY, de um mandato de otimização jurídica ${ }^{49}$. É, também, o momento mais criticado do controlo de proporcionalidade, acusado de ser "obs-

\footnotetext{
43 Bernhard Schlink, Proportionality, p.722-23.

44 Bernhard SCHLink, Proportionality, pp.723-724.

45 Apud Suzana Tavares Da Silva, O tetralemma, p. 645.

46 Para as quais adverte Bernhard SCHLInK, Proportionality, p.723-724.

47 Bernhard SCHLInK, Proportionality, p.724.

48 Suzana Tavares da Silva, O tetralemma, pp. 645-646.

49 Apud Suzana Tavares Da Silva, O tetralemma, p. 645.
} 
curo", subjetivo e vago, e discutindo-se se e em que medida pode ser preciso ou objetivo ${ }^{50}$, o que leva alguns autores, como AlEXY ou AHARON BARAK, a propor metódicas de aplicação destinadas a conferir-lhe maior objetividade ${ }^{51}$. Entre aqueles que o defendem, parece haver consenso no sentido de ser necessário atender a todos os factos, interesses, direitos, princípios e valores relevantes, bem como levar a cabo uma análise cuidadosa do impacto que neles produzirão os diferentes resultados do conflito, sintetiza SCHLINK ${ }^{52}$. A isto se voltará infra.

Ainda neste contexto, cumpre aludir à questão de saber se deve existir ou não uma ordem para a análise da proporcionalidade. Segundo DieTER GRIMM, a questão da existência ou não de uma ordem aplicativa é relevante: questionar a legitimidade do fim, passando depois à adequação, de seguida à necessidade e finalmente ao balanceamento tem um efeito disciplinador e racionalizador ${ }^{53}$.

50 Bernhard Schlink, Proportionality, pp.724-725. Como escreve BernHARD SCHLINK, Proportionality, p. 724, o balanceamento envolve valores e julgamentos de valor, pelo que é o passo mais contestado da análise da proporcionalidade, suscitando questões sobre como evitar que seja um terreno de subjetividade, como verificar um julgamento de valor, quão preciso pode ser o balanceamento e se pode produzir resultados objetivos.

51 Bernhard Schlink, Proportionality, pp. 724-725. Segundo este, Alexy propõe determinar os custos que representa para cada um dos lados se o outro lado ganhar e se o ganho de um dos lados justifica a afetação do outro, de acordo com uma escala de realização. Segundo a sua "lei de ponderação", quanto maior o grau de não satisfação ou afetação de um princípio, maior deve ser o grau de satisfação do outro princípio, $v d$. ROBERT ALEXY, Los derechos fundamentales y el principio de la proporcionalidade, pp. 15 ss. AHARON BARAK, Proportionality, pp. 744-745 propõe o balanceamento entre a importância social do benefício obtido com a realização do fim e a importância social de evitar a limitação do direito constitucional em causa. A solução, escreve, é consistente com a lei de balanceamento de ALEXY, mas distingue-se da abordagem do autor alemão pois este não leva em conta a importância social do fim e do direito em causa, mas apenas o grau de limitação (ob. cit., p. 746).

52 Bernhard SCHLink, Proportionality, p. 725.

53 Dieter Grimm apud Bernhard Schlink, Proportionality, p. 725. Entre nós, o Tribunal Constitucional estabelece ainda uma relação sequencial entre os três momentos do teste: primeiro adequação, depois necessidade, depois proporcionalidade em sentido estrito, $v d$. Pedro Machete / Teresa Violante, 
Por outro lado, evitam-se controlos desnecessários: se a medida não for adequada, nem sequer valerá a pena verificar se é necessária ou proporcional em sentido estrito. Porém, sem prejuízo da discussão sobre a adequação sequencial, as questões mais controversas relativas à estrutura da proporcionalidade são, para SCHLINK, a intensidade, o tipo (geral ou particular) ${ }^{54}$ e o âmbito do controlo judicial a efetuar, o que coloca a questão da relação entre os poderes legislativo e judicial no âmbito da constituição ${ }^{55}$.

\section{As debilidades do princípio da proporcionalidade}

As críticas ao princípio da proporcionalidade são de vários tipos $^{56}$, dirigindo-se ora à estrutura e configuração dos testes de proporcionalidade, ora às vicissitudes da sua aplicação. Apesar de as críticas se dirigirem sobretudo à proporcionalidade em sentido estrito ou balanceamento ${ }^{57}$, é oportuno ampliar um pouco o âmbito desta reflexão, até porque a proporcionalidade não se circunscreve ao momento do balanceamento.

\footnotetext{
O princípio da proporcionalidade e da razoabilidade na jurisprudência constitucional, e jurisprudência aí citada.
}

54 Bernhard Schlink, Proportionality, pp. 726-727.

55 Bernhard SCHLinK, Proportionality, p. 725-726.

56 As críticas podem ser dirigidas aos chamados aspetos internos ou aos aspetos externos, tal como propõe AHARON BARAK, Proportionality, p. 749, que aqui seguimos parcialmente. Segundo BARAK, p. 750, a crítica interna insiste na inexistência de um denominador comum que permita o balanceamento, ao passo que as críticas externas tomam várias formas (a saber: o balancing concede ao juiz um excesso de discricionariedade, pondo em risco a certeza jurídica e a proteção dos direitos humanos; o balanceamento cabe ao legislador, logo um juiz que o faça está a pôr em causa a separação de poderes e a agir de forma não democrática; o juiz não tem as ferramentas adequadas para proceder ao balanceamento: as características do processo judicial tornam a perspetiva judicial muito estrita, e o juiz tem dificuldade em lidar com dados empíricos; a perspetiva judicial limita a discricionariedade ao ponto de praticamente não incluir o balanceamento).

57 Neste sentido, também Aharon BARAK, Proportionality, p. 749. Para uma comparação entre balanceamento na doutrina norte-americana e proporcionalidade de base alemã, $v d$. supra nota 6 e, por todos, Moshe COHEN-Elyia e IDDO PORAT, Proportionality and constitutional culture. 


\section{a) O problema do enfraquecimento dos direitos}

Uma crítica frequente ao princípio da proporcionalidade é a de que relativiza e enfraquece os direitos e liberdades, que são colocados no mesmo patamar que os interesses do Estado ou interesses coletivos com os quais são contrapesados, e sopesados em igualdade de circunstâncias, com resultados incertos ${ }^{58}$ que frequentemente exigem o seu sacrifício. Assim, não só não são a priori mais fortes do que os interesses prosseguidos pelo Estado e invocados para a sua limitação, como são mais fracos, sendo protegidos apenas na medida em que não exista um interesse estadual contraposto que justifique a sua afetação $0^{59}$. Deste ponto de vista, sustenta-se, dizer que se tem um direito constitucionalmente protegido não significa nada, pois o resultado é contingente, o que torna a constituição fútil e coloca os direitos nas mãos das maiorias ${ }^{60}$. Ou seja, torna os direitos fracos, e estes deixam de poder valer como trunfos (ao menos num sentido forte) ${ }^{61}$. Em sede de balanceamento, as dimensões deontológicas subjacentes aos direitos seriam afastadas por raciocínios de tipo consequencialista ${ }^{62}$.

58 StaVros TSAKYrakis, Proportionality, pp.724-725. Segue-se aqui a crítica ao balancing realizada por TSAKYRAKIS, partindo dos EUA e da sua aplicação no âmbito da Convenção Europeia de Direitos Humanos, mas que nos parece poder ser seguida.

59 Bernhard SCHLINK, Proportionality, p. 732, escrevendo que a proteção é relativizada, diz-se, pois um direito ou liberdade apenas é protegido na medida em que o Estado não tem um interesse legítimo que exija a sua limitação ou afetação; não é mais forte do que o interesse legítimo do Estado; na verdade, é mais fraco, pois se uma posição puder ser salvaguardada apenas com sacrifício da outra, o interesse coletivo das pessoas tal como representado pelo Estado irá trunfar o direito singular do cidadão individual.

60 Stavros TSAKYrakis, Proportionality: An assault on human rights? p. 471.

61 Sobre a crítica da conceção liberal dos direitos como trunfos à proporcionalidade, vd. Mattias Kumm / Alec D. Walen, Human Dignity and Proportionality: Deontic pluralism in balancing, pp. 1 ss. (2 de janeiro, 2013), Proportionality and the Rule of Law: Rights, Justification, Reasoning, Huscroft, Miller and Webber, eds. (forthcoming), NYU School of Law, Public Law Research Paper No. 13-03, 2013. Disponível em SSRN: https://ssrn.com/abstract=2195663p. 1. Vd. ainda Matthias Klatt / MORItz Meister, Proportionality, pp. 688 ss.

62 Sobre a questão e o risco de instrumentalização da pessoa humana, $v d$. MATTIAS Kumm / Alec D. Walen, Human Dignity and Proportionality, pp. 2 ss. 
Neste contexto, um risco especificamente identificado é o de vulneração da dignidade da pessoa humana ${ }^{63}$. Da proteção da dignidade da pessoa humana, ou do reconhecimento de um núcleo essencial do direito que não pode ser afetado em sede de ponderação ${ }^{64}$, decorreria a existência de limites absolutos ao balanceamento, exigindo um mínimo de densificação moral prévia ${ }^{65}$.

\section{b) A questão da neutralidade moral da proporcionalidade}

Assim, associada à crítica anterior surge uma outra, a da neutralidade moral da proporcionalidade. Com efeito, alega-se, a proporcionalidade é um expediente neutro que não dá uma resposta quanto ao resultado, mas essa neutralidade mascara e obscurece a dimensão moral dos direitos. Para TSAKYRAKIS, o balanceamento sob a forma

63 Sobre a questão, vd. Mattias Kumm / Alec D. Walen, Human Dignity and Proportionality. Segundo os autores, existe o receio de que o recurso ao teste da proporcionalidade (que está no centro de grande parte da adjudicação contemporânea de direitos humanos e constitucionais) seja um convite equivocado e perigoso ao balanceamento da dignidade humana. A posição dos autores é, contudo, a de que a proporcionalidade, designadamente o teste de balanceamento, permite acolher dimensões morais, e de que, compreendida a estrutura complexa do balanceamento, este não é incompatível com a proteção da dignidade da pessoa humana, antes permite e exige levá-la em conta.

64 Como escreve Stavros TSAKYrakis, Proportionality, passim, em especial pp. 492-493: "The position that there is an inviolable core content of the right implies a substantive moral assessment about what is right and wrong. Once we have accepted that this core content cannot be compromised under any circumstances, we have left behind the idea that the right at stake can be weighed against competing public interests. Put simply, there is no balance to talk about in the first place. This explains why definitional generosity, no matter how broadly we understand it, can never accommodate certain rights-restricting reasons. (...). A court that assumes that there is an absolute minimum to each right is no longer concerned with issues of intensity and degree, and, thus, proportionality". Criticando esta perspetiva, sustentando que a proporcionalidade permite proteger o núcleo essencial, vd. Matthias Klatt / MORITz MeISTER, Proportionality, pp. 691 ss. Entre nós, veja-se o n. 3 do $\operatorname{artigo~} 18 .^{\circ}$ da Constituição portuguesa e as diferentes leituras sobre o caráter absoluto ou relativo a proteção do núcleo essencial.

65 StaVros TSAKYrakis, Proportionality, passim, em especial pp. 492-493. 
de proporcionalidade prejudica, mais do que ilumina, a adjudicação de direitos: já não perguntamos o que está certo ou errado num caso de direitos humanos, antes tentamos determinar se algo é apropriado, adequado ou excessivo ${ }^{66}$. Para o autor, ao obscurecer as referidas considerações morais, a sociedade é privada de um discurso moral indispensável e da discussão sobre os desacordos morais, mascarados pela "linguagem pretensamente neutra" do balanceamento sob a forma de proporcionalidade ${ }^{67}$.

Tal relaciona-se ainda, sustenta-se, com a opção metodológica por uma conceção ampla do âmbito de proteção dos direitos, a chamada "definitional generosity" 68 . Esta generosidade fornece inclusividade a troco de superficialidade, sustenta TSAKYRAKIS ${ }^{69}$, e não permite afastar interesses baseados em justificações que deveriam ser excluídas à partida - aquilo a que chama as justificações ilícitas, que põem em causa a própria função de justificação dos direitos. A determinação do conteúdo de um direito, escreve, exige determinarmos o que ele tem de valioso e qual o seu lugar na constelação de valores políticos e morais da comunidade, ou seja, exige uma argumentação moral, que se perde com a adoção de uma perspetiva ampla sobre o âmbito de proteção $^{70}$.

\section{c) O problema da (in)comensurabilidade e do rigor}

Tudo pode ser medido e comparado? A possibilidade de uma métrica comum é problemática. A "metáfora do balanceamento", sustenta-se, nada diz sobre o peso ou sobre a forma como os diversos interesses devem ser contrapesados, e isso esconde sob a fachada de uma métrica comum, "mecânica e quantitativa", a impossibilidade

66 Stavros TSakyrakis, Proportionality, p. 487.

67 Stavros Tsakyrakis, Proportionality, p. 493. Entre nós, JORge ReIs Novais complementa o princípio da proporcionalidade com as dimensões da razoabilidade e determinabilidade, perspetiva que, para SuZANA TAVARES DA SILVA, O tetralemma, p. 648, pode ser vista como incorporando a (negligenciada) dimensão moral do princípio.

68 Stavros Tsakyrakis, Proportionality, p. 480.

69 Stavros Tsakyrakis, Proportionality, p. 488.

70 StaVros TSAKYrakis, Proportionality, p. 488. 
de medir valores que são incomensuráveis ${ }^{71}$. Ora, sem comensurabilidade, sustenta-se, o balanceamento não é racional, mas intuitivo, improvisado, subjetivo e impreciso, ainda que forneça uma falsa aparência de calculabilidade ${ }^{72}$ e, mesmo, de cientificidade ${ }^{73}$.

A única forma de conseguir comparabilidade seria, para TSAKYRAKIS, adotar uma forma de utilitarismo que reconduzisse todos os interesses a uma métrica comum (de felicidade, satisfação ou dinheiro), o que não só seria difícil como contraproducente (pois, caso fosse possível fazê-lo, o balanceamento deixaria de ser necessário ${ }^{74}$. Em suma, o "balancing" traduz uma forma de raciocínio apelativa e inclusiva, projetando uma imagem de simplicidade, inclusão (de interesses e razões) e de precisão, pois assume que podemos medir e calcular o peso relativo das $\operatorname{coisas}^{75}$. Porém, faltar-lhe-ia precisamente rigor.

d) A questão da relação entre legislador e juiz num contexto democrático e de separação de poderes

As críticas relativas à relação entre legislador e juiz são alimentadas por considerações relativas, seja à legitimidade democrática e à separação e interdependência de poderes, seja às características específicas da função judicial que determinam a sua limitação funcional. Quanto às primeiras, alega-se que, em democracia,

71 Stavros Tsakyrakis, Proportionality, p. 471, citando em nota Paul W. Kahn, The Court, The Community and the Judicial Balance: The Jurisprudence of Justice Powell: "The concept of «balancing» is itself both a metaphor and an abstraction. The metaphor is ambiguous. It describes both a process of measuring competing interests to determine which is "weightier» and a particular substantive outcome characterized as a «balance» of competing interests. The abstract concept of balancing, furthermore, tells us nothing about which interests, rights, or principles are weighted or how the weights are assigned." $V d$. ainda AHARON BARAK, Proportionality, p. 750, que designa esta crítica por crítica interna.

72 Sobre a crítica da falsa impressão de calculabilidade, $v d$. MATthias KLATT / MORITZ MEISTER, The constitutional structure of proportionality, apud MATTIAS Kumm / Alec D. Walen, Human Dignity and Proportionality, p. 1.

73 Aharon Barak, Proportionality, p. 750.

74 Stavros TSAKYrakis, Proportionality, p. 471.

75 Stavros TSAKYrakis, Proportionality, p. 469. 
o balanceamento cabe ao legislador, pelo que um juiz que faça balanceamento está a pôr em causa a separação de poderes e a agir de forma não democrática ${ }^{76}$. Quanto às segundas, sustenta-se que o juiz não tem as ferramentas adequadas para proceder ao balanceamento, dadas as características do processo judicial e a dificuldade em lidar com dados empíricos ${ }^{77}$.

A proporcionalidade integrada pelo balanceamento, alega-se ainda, concede ao juiz um excesso de discricionariedade, pondo em risco a certeza jurídica e a proteção dos direitos humanos ${ }^{78}$. Ora, em rigor, o receio pelo excesso de discricionariedade e o perigo que daí advém para a proteção dos direitos resulta da ponderação em si mesma, creê-se, e não especificamente da que é feita pelo juiz, e por isso é independente da questão da separação e interdependência de poderes e da legitimidade para dizer o Direito.

Por outro lado, apesar de muitas vezes dirigida ao momento do balanceamento, a problemática da determinação dos limites entre legislador e juiz também se faz sentir, designadamente, no momento da necessidade, podendo discutir-se se e em que medida se justifica o controlo da necessidade (ou da escolha da medida) pelo poder judicial, no respeito pela liberdade de conformação do legislador ${ }^{79}$.

76 Aharon Barak, Proportionality, p. 750 e Bernhard Schlink, Proportionality, 2012, pp. 735 ss. SCHLINK, p. 735 escreve que tolerar o "balancing" judicial significa modificar o padrão democrático e aceitar como equivalentes legitimidade democrática direta - a do legislador - e indireta - a do juiz, bem como traduz uma certa desconfiança no procedimento de decisão parlamentar e confiança na decisão judicial.

77 Segue-se aqui Aharon BARAK, Proportionality, p. 750.

78 Aharon BArak, Proportionality, pp. 750-751.

79 Suzana TAVARES DA Silva, O tetralemma, pp. 647 ss., aludindo às perspetivas de Gomes Canotilho, que torna "inoperativo" o teste de necessidade, de Vieira de Andrade, que propõe a sua substituição pelo teste da razoabilidade, e Jorge Reis Novais. 


\section{Perspetivas para uma resposta aos críticos: a importância da análise de proporcionalidade}

a) O problema de desvalorização dos direitos

Uma das críticas vistas supra é a de que a proporcionalidade fragiliza a posição dos direitos ${ }^{80}$, desde logo colocando em pé de igualdade direitos e liberdades, por um lado, e interesses coletivos, por outro.

Por um lado, não é certo que o conflito se configure sempre como uma contraposição entre um direito e um interesse do Estado ou da comunidade. E se o fim for a salvaguarda de outro direito, por vezes do mesmo direito que estamos a ponderar sacrificar $(v d$. o caso do abate de aeronaves ${ }^{81}$ ), caso em que estaremos a balancear direito contra direito? Por outro lado, como nota SCHLINK, é uma simplificação excessiva, ou mesmo um erro, entender que os direitos e liberdades individuais estão sempre em oposição ao interesse estadual, desde logo porque o Estado tem também interesse em que os cidadãos gozem as suas liberdades, sendo estas frequentemente também bens coletivos ${ }^{82}$, fruto, diríamos nós, da sua dimensão objetiva.

Esta primeira questão supõe uma determinada conceção sobre a proteção dos direitos e o seu papel como trunfos. Mas, na verdade, não fecha a questão, pois podemos entender que a ponderação é inevitável e, mesmo assim, reforçar a posição dos direitos, não

80 Remete-se aqui para os argumentos aduzidos por BERNHARD SCHLINK, Proportionality, 2012, pp. 732-735, para rebater esta crítica.

81 Veja-se o caso decidido pelo Tribunal Constitucional Alemão relativo à autorização para abate de aeronaves em caso de suspeita de ataque terrorista, BVerfG, Urteil des Ersten Senats vom 15 Februar 2006 - 1BvR357-, Rn.1-156. Disponível em http://www.bverfg.de/e/rs20060215_1bvr035705en.html Sobre este, entre nós, JOR GE Silva SAMPAIO, O caso alemão da "Lei de segurança da aviação" e a norma da dignidade da pessoa humana à luz de uma análise estrutural, in JORGE Reis Novais e Tiago Fidalgo De Freitas, $A$ dignidade da pessoa humana na justiça constitucional, Coimbra, Almedina, 2018, p. 529 ss.

82 BernhARD SCHLINK, Proportionality, 2012, pp. 732-725. O autor dá o exemplo da liberdade de expressão e de imprensa, que é um direito individual e uma garantia democrática e de controlo do exercício de poder associada ao mercado livre de ideias. 
abdicando de os entender como trunfos, ainda que porventura num sentido mais débil ${ }^{83}$. É a perspetiva de KLATT e MEISTER, para quem o controlo de proporcionalidade não é incompatível com a conceção dos direitos como trunfos em sentido "soft" ("soft trumping"), pois os direitos mostram a sua força, seja no momento da determinação dos fins (legítimos), exigindo que apenas contem para efeito de ponderação outros valores constitucionais, seja no momento do balanceamento propriamente dito, em que podem assumir maior peso abstrato do que outras considerações em jogo, desde logo por determinação constitucional ${ }^{84}$. Como, de outra perspetiva, escreve SCHLINK, os direitos e liberdades podem mostrar a sua força de outras formas, isto é, excluindo razões, e isto mesmo entendendo a análise da proporcionalidade como um processo de argumentação e decisão no qual, prima facie, tudo pode ser invocado contra e a favor da adequação ou necessidade de uma medida e do balanceamento entre meios e fins, pois os direitos podem precisamente reduzir este universo, excluindo certos fins como legítimos ( $v d$. supra) ${ }^{85}$.

Em todo o caso, escreve BARAK, nem há à partida nenhuma razão para achar que um juiz protege menos os direitos num sistema que recorra à proporcionalidade (baseada no balanceamento) do que num sistema qualquer alternativo, já que a proporcionalidade é uma forma que tem de ser preenchida com um determinado conteúdo,

${ }^{83}$ Sobre os subtipos - forte, médio e fraco - da teoria dos trunfos, $v d$. SUSANA TAVARES DA Silva, O tetralemma, p. 648-649.

${ }^{84}$ Matthias Klatt / MOritz Meister, Proportionality, pp. 690 ss. Os autores definem o peso abstrato como "o peso que um princípio detém relativamente a outros princípios, independentemente das circunstâncias do caso", podendo os princípios ter diferentes pesos abstratos, desde logo por determinação constitucional, conduzindo à seguinte lei ("law of trumping"): "quanto maior o peso abstrato de um direito, com maior probabilidade trunfará considerações concorrentes". Esta força resultante do peso abstrato não determina o resultado do balanceamento, não se tratando de "razões categóricas", mas do que designam por "prima facie trumping".

85 Bernhard Schlink, Proportionality, pp. 732-725. Para o autor, também a atribuição do ónus da prova à "entidade intrusiva”, o Estado, maxime o Estado legislador, reforça os direitos e liberdades individuais, ainda que se suscitem problemas. 
permitindo diferentes níveis de proteção ${ }^{86}$. SCHLINK sublinha, por seu turno, a inconclusividade da ligação entre balanceamento judicial e direitos, uma vez que o balanceamento judicial tanto pode fortalecer como enfraquecer os direitos, sendo a incerteza que lhe está associada problemática, outrossim, do ponto de vista da legitimidade democrática ${ }^{87}$.

\section{b) Proporcionalidade e dimensões morais}

Relacionando-se com estas dificuldades, surge o problema dos limites: não estaremos a pedir ao princípio da proporcionalidade que nos dê algo que já devia estar dado, os limites morais das medidas estaduais ${ }^{88}$ ?

Como se viu supra, uma das críticas ao princípio da proporcionalidade é a sua neutralidade moral. Esta crítica é rebatida por MÖLlER ${ }^{89}$, sustentando que o facto de o princípio em si ser uma "fórmula vazia", na medida em que se traduz num procedimento metódico abstratamente delineado cujo resultado concreto não está pré-determinado, não significa que a análise de proporcionalidade seja conduzida de forma moralmente neutra, ou com rejeição de argumentos morais: abstração não se confunde com neutralidade moral. Tanto assim é, argumenta, que apenas os fins legítimos podem ser usados para justificar uma afetação do direito, o que é controlado

${ }^{86}$ Aharon BARAK, Proportionality, pp. 750-751, que acrescenta que não haver prova de que, em termos práticos, a proteção dos direitos humanos seja menor em sistemas que apliquem a proporcionalidade e o balanceamento do que em outros sistemas.

${ }^{87}$ Bernhard SCHLink, Proportionality, pp. 734-735. Quando o resultado da operação de balanceamento é incerto e subjetivo, coloca-se a questão de saber porque deve a subjetividade do juiz prevalecer sobre a do legislados. "Decisões subjetivas sobre a prossecução do bem comum são intrinsecamente políticas", escreve, e a sua legitimação deve provir do processo democrático. O "balancing" judicial não é problemático quando corrige decisões de tribunais ou da administração, mas quando corrige decisões do legislador.

${ }^{88} V d$. a propósito o que escreve, sobre cálculos de proporcionalidade e guerra, MiCHAEL WALZER, El argumento de la proporcionalidade, Letras Libres, n. ${ }^{\circ} 89$, 2009, pp. 39-40. Online em www.letraslibres.com.

89 KAI MÖLLER, Proportionality, pp. 716 ss. 
logo no início da metódica da proporcionalidade. Para MÖller, o próprio conceito de proporcionalidade é moral e abre-se a considerações morais.

Esta discussão ilumina uma certa ambivalência do princípio da proporcionalidade. Por um lado, a proporcionalidade surge como uma espécie de "norma de segundo grau" (no sentido de Hart) sobre a forma de concretização de outros princípios ou de exercício da competência, "fórmula vazia" prescrevendo uma metódica ou um procedimento ${ }^{90}$ mas sem pré-determinar o resultado e sendo, nesse sentido, instrumental. Por outro lado, tem igualmente um núcleo substancial, que é a ideia de justa medida, proibição do excesso (ou do défice), que não está pré-definida, mas tem de ser concretizada, com natureza e estrutura de princípio $^{91}$, cuja realização se materializa precisamente num procedimento e, nesse sentido, tem também uma intencionalidade específica de natureza moral. Finalmente, a metódica de aplicação do princípio está aberta a considerações morais.

Para MÖLlER, a aplicação do princípio da proporcionalidade supõe uma argumentação moral. Com efeito, os juízes agem balizados pelas constituições ou instrumentos de proteção de direitos que fornecem balizas morais, e a proporcionalidade obriga o juiz a desenvolver uma justificação (argumento moral) acerca do contrapeso aceitável de razões ${ }^{92}$. O princípio da proporcionalidade não impede que se atinjam maus resultados, mas o problema não reside, nesse caso, no princípio, mas na forma como foi usado.

Do mesmo modo, a crítica à generosidade na determinação do âmbito do direito, que não permite excluir as "justificações ilícitas", é, em rigor, externa ao princípio da proporcionalidade. Com efeito, parece-nos, por um lado, que a proporcionalidade não exige uma teoria alargada do âmbito de proteção. Por outro, não há nenhum

$90 V d$. Vitalino Canas, O princípio da proibição do excesso na conformação e no controlo de atos legislativos, Coimbra, Almedina, 2017, p. 890.

91 Vitalino CANAS, O princípio, 2017, p. 898, pronuncia-se no sentido de a proporcionalidade como norma de ação se aproximar do conceito de regra e a proporcionalidade como norma de conteúdo se aproximar do conceito de princípio.

92 KAI MÖLLER, Proportionality, p. 717. 
obstáculo a que se entenda que apenas depois de determinado o âmbito de proteção da norma (e os candidatos positivos à inclusão nesse âmbito) entra em cena a proporcionalidade, ou a que as justificações ilícitas podem, precisamente, ser excluídas no controlo da legitimidade dos fins (para alguns, primeiro teste do controlo da proporcionalidade) ${ }^{93}$.

Mattias Kumm e Alec D. WALEN alertam para a complexidade do balanceamento e para o pluralismo de argumentações morais. Argumentam que o balanceamento não só não afasta, como pressupõe, a deontologia, mas que esta é, ela própria, estruturalmente pluralista ("pluralismo deôntico"), no sentido em que abrange vários tipos de razões que justificam que concedamos mais peso a uns interesses do que a outros ${ }^{94}$. Não propõem uma conceção abrangente de balanceamento que determine qual será o equilíbrio certo em todos os casos, argumentam apenas que a operação de balanceamento terá que fazer referência apropriada às restrições que surgem do respeito pela dignidade e sua tradução nos casos sob análise $e^{95}$. O balanceamento, escrevem, não é mecânico, antes exige ao decisor que leve em conta todas as dimensões relevantes que não foram tidas em conta nas fases anteriores do princípio da proporcionalidade (legitimidade dos meios, adequação, necessidade); sobretudo, não há uma tensão entre balanceamento, por um lado, e deontologia e dignidade

93 KAI MÖLlER, Proportionality, p. 718.

94 Compreendendo, mas não se circunscrevendo, à proibição de utilização de pessoas como meios (e não como fins), ela mesma suscetível de diferentes entendimentos, Mattias Kumm / Alec D. Walen, Human Dignity, pp. 3-4. Os autores ilustram a sua afirmação discutindo, não apenas a instrumentalização das pessoas contra a sua vontade, mas outros casos em qua as considerações deontológicas são relevantes no balanceamento, mas não se apresentam como "side constraints", antes como razões a ter em conta no balanceamento, $v d$. MATTIAS Kumm / Alec D. WALen, Human Dignity, pp. 4 ss. Veja-se, para a proibição de instrumentalização, o caso decidido pelo Tribunal Constitucional Alemão relativo à autorização para abate de aeronaves em caso de suspeita de ataque terrorista, BVerfG, Urteil des Ersten Senats vom 15 Februar 2006 - 1BvR357-, Rn.1-156.

95 Mattias Kumm / Alec D. Walen, Human Dignity, p. 4. 
da pessoa humana, por outro96. "A proporcionalidade é apenas a estrutura que guia os juízes no processo de argumentação e decisão sobre se uma determinada medida respeita ou não os direitos", escreve MÖLLER, fazendo-os procurar um fim legítimo, determinar se as medidas são adequadas e necessárias e, finalmente, se não são excessivas e, nesse sentido, a análise de proporcionalidade é análise moral ${ }^{97}$ que fornece ao juiz uma ferramenta analítica poderosa para decompor uma questão complexa em momentos e, dessa forma, justificar melhor a sua decisão ${ }^{98}$.

Assim sendo, do que se trata não é de afastar dimensões morais do âmbito do balanceamento, mas de assumir que a argumentação moral possa assumir uma variedade de formas, com reflexos no modus operandis da operação de balanceamento. MöLlER identifica duas aceções diferentes de balanceamento, que correspondem a duas formas de argumentação moral ${ }^{99}$ - balanceamento como contrapeso de interesses ou análise custo-beneficio ("interest balancing”), que pressupõe que os direitos e interesses sejam medidos e os seus pesos relativos comparados, e balanceamento como argumentação ("balancing as reasoning"), sendo neste sentido que surge muitas vezes nas controvérsias constitucionais. Entende que o que é problemático - e, nesse caso, foi bem identificado pelos críticos - é o entendimento de que o balanceamento deve ser sempre feito em termos de custo-benefício ${ }^{100}$.

$\mathrm{Ou}$ seja, esta forma de entender o balanceamento permite que questões deontológicas ou argumentos morais possam intervir nesta

96 Mattias Kumm / Alec D. Walen, Human Dignity, pp. 22-23. Segundo os autores, ob. cit., p. 22, é um erro pensar que os direitos humanos têm uma estrutura dupla, parcialmente sujeitos ao balanceamento e parcialmente deontológicos, dada a ligação à dignidade da pessoa humana, antes o discurso moral subjacente ao balanceamento é deontológico e baseado na dignidade humana; por outro lado, a perspetiva deontológica da dignidade não se circunscreve a uma conceção, a da proibição de usar as pessoas como meios ao serviço dos fins de outrem, é estruturalmente pluralista.

97 KAI MÖLLER, Proportionality, p.726.

98 KAI MÖLlER, Proportionality, p.727.

99 KAI MÖller, Proportionality, p. 715.

100 KAI MÖlleR, Proportionality, p. 730. 
sede, e que intervenham de forma imparcial, enquanto "inclusão de razões". Deste ponto de vista, o princípio da proporcionalidade pode ser visto como instrumento de acomodação do pluralismo. Como se escreveu já, "assumindo que o Estado não pode ser totalmente neutro quanto aos fins (porque não é uma entidade abstrata, mas uma realidade histórica e formada por pessoas que, em termos práticos, orientam a sua ação por fins comuns), poderemos continuar a sustentar que o seja quanto ao modo de atuação e eleição dos referidos fins, perante a inevitabilidade das escolhas em contextos plurais" ${ }^{101}$. Do ponto de vista da justificação, a neutralidade aproximar-se-ia do conceito de imparcialidade como obrigação de inclusão de todos os interesses relevantes, sob pena de défice ou ausência de ponderação, prosseguindo o igual respeito entre todos os afetados e reforçando a tutela das minorias ${ }^{102}$.

c) Diferentes aceções de incomensurabilidade e a racionalização do balanceamento

Uma das críticas ao balanceamento centra-se na impossibilidade de comparar os bens em presença, ou incomensurabilidade. Ora esta incomensurabilidade pode ser tomada em diferentes aceções, ou mesmo dispensada ${ }^{103}$. Uma vez mais, como se viu no ponto anterior, do que se trata é de determinar que conceção de balanceamento adotar.

MÖLLER decompõe o conceito em incomensurabilidade forte, em que realmente não temos argumentos para comparar e preferir, e incomensurabilidade fraca, caso em que podemos relacionar ambos os valores e temos critérios para os ordenar (por exemplo,

101 ANABELA COSTA LEÃO, Constituição e interculturalidade: da diferença à referência, Dissertação de doutoramento apresentada à FDUNL, 2013, p. 211.

102 Anabela COSTA LEÃO, Constituição, pp. 211-212 e bibliografia de suporte aí citada.

${ }^{103} \mathrm{Ou}$ mesmo dispensada ou substituída, no sentido proposto por BRUCE CHAPMAN, Incommensurability, proportionality, and defeasibility, Law, Probability, and Risk, 12, 3-4, 2013, pp. 259 ss. 
prioridade lexical) ${ }^{104}$. Muitas das situações são situações de incomensurabilidade fraca, em que a ponderação enquanto "ponderação de todas as considerações relevantes", no sentido proposto por MÖLLER ${ }^{105}$, pode ajudar a determinar qual dos direitos ou interesses deve em concreto prevalecer, mesmo sem ou para além de uma análise custo-benefício em sentido estrito, e.g. económico. Caso se chegue à conclusão de que se está perante um caso de incomensurabilidade forte, em que não é possível desenvolver um raciocínio argumentativo que conduza à "resposta certa", então parece que terá de ser o legislador a optar e que o juiz não poderá controlar essa opção ${ }^{106}$. Mas, como bem nota MÖLlER, a questão da comensurabilidade não é decisiva - mesmo que os dois bens em conflito sejam comensuráveis, daí não resulta que possamos simplesmente resolver o caso com base em números ${ }^{107}$.

Já para AHARON BARAK, a fase do balanceamento supõe uma análise da relação entre o beneficio social que resulta da realização do fim (promover um interesse público ou proteger um direito) e o benefício social que resulta de evitar a limitação do direito constitucional em causa, em termos de benefício social marginal ${ }^{108}$.

104 KAI MÖLLER, Proportionality, pp. 719 ss., retomando a distinção entre tipos de incomensurabilidade proposta por Waldron.

${ }^{105}$ KAI MÖLLER, Proportionality, p.721.

${ }^{106}$ KAI MÖLlER, Proportionality, p.722.

107 KaI MÖller, Proportionality, p.719. O autor dá como exemplo um hipotético caso em que o Estado exigisse que uma pessoa ao acaso fosse morta para que os seus órgãos pudessem salvar cinco pessoas, em que o facto de o bem em causa ser o mesmo - a vida - não permite simplesmente concluir que cinco vidas valham mais do que uma, justificando a medida. Uma vez mais, o já referido caso do abate de aviões decidido em 2006 pelo BVerfG permitiria ilustrar esta hipótese.

108 Aharon Barak, Proportionality, pp. 744-745. Para o autor, ob. cit., p. 745, e como se referiu já, trata-se de determinar quando um fim legítimo pode ser prosseguido mesmo que tal implique a limitação de um direito constitucional, o que supõe o balanceamento entre a importância social do benefício obtido com a realização do fim e a importância social de evitar a limitação do direito constitucional em causa. A solução, escreve, é consistente com a lei de balanceamento de AlEXY, mas distingue-se da abordagem do autor alemão pois este não leva em conta a importância social do fim e do direito em causa, mas apenas o grau de limitação, escreve (ob. cit., p. 746). 
Assim sendo, existe um denominador comum que permite que o balanceamento seja racional, afastando a acusação de ser impreciso e subjetivo devido à incomensurabilidade, sendo esse denominador comum a importância social de realizar um princípio e evitar a limitação de outro princípio ${ }^{109}$.

Também Klatt e MeISTER rebatem a objeção da incomensurabilidade, sustentando que não é decisiva: o balanceamento exige comparabilidade, mas não comensurabilidade (em sentido forte ou fraco), e a comparabilidade estabelece-se através da criação de uma escala comum ${ }^{110}$.

\section{d) Ilegitimidade do controlo judicial}

As críticas à alegada ilegitimidade e falta de democraticidade do balanceamento judicial podem ser rebatidas com vários argumentos.

Por um lado, pode invocar-se a sua legitimidade ou credencial constitucional - é a constituição a estabelecer, expressa ou implicitamente, o controlo judicial, em geral, e a autoridade do juiz para balancear princípios contrapostos ao escrutinar a limitação de um direito, em particular, escreve BARAK ${ }^{111}$. Por outro lado, pode sustentar-se que o "balancing" judicial preserva, ao invés de prejudicar, a democracia e a separação de poderes, havendo uma repartição de tarefas que confere ao legislador a possibilidade de balancear interesses públicos e direitos individuais e ao juiz o poder de "última palavra", através do qual se garante a proteção constitucional dos direitos, se realiza a democracia em sentido material e o equilíbrio

109 Aharon Barak, Proportionality, p. 750. Trata-se, em suma, de saber se benefício social marginal de efetivar um princípio é suficiente para justificar a limitação marginal do outro, escreve. Para o autor, ob. cit., loc. cit., tal fornece ao balanceamento uma base racional, que não desaparece pelo facto de, por vezes, se conceder alguma discricionariedade a quem o faz (seja o juiz, o legislador ou a administração).

110 Matthias Klatt / Moritz Meister, Proportionality, pp. 696 ss.

111 Aharon BARAK, Proportionality, p. 751. De resto, para o autor, se a constituição não quiser que o juiz recorra à proporcionalidade em geral e ao "balancing" em particular, deve dizê-lo expressamente. 
entre regra da maioria e direitos individuais ${ }^{112}$. Para isto contribuiriam a estrutura institucional e a independência dos tribunais, bem como a sua distância de pressões políticas ${ }^{113}$.

As objeções ou dificuldades inerentes à ponderação ou, mais amplamente, à análise da proporcionalidade feita pelo juiz não se afastam, em geral, das objeções ou dificuldades inerentes à fiscalização jurisdicional de atos do legislador, como escreve BARAK ${ }^{114}$, ou das objeções apresentadas ao chamado "constitucionalismo principialista", acusado de debilitar a certeza e a segurança na aplicação do Direito, conceder demasiado à ponderação e favorecer a "jurisdicionalização das escolhas políticas" legitimando o ativismo judicial $^{115}$, maxime do Tribunal Constitucional, ou, noutro plano ainda, da discussão mais ampla sobre a "guarda dos direitos" em Estados constitucionais democráticos caracterizados pelo pluralismo ${ }^{116}$.

Como se escreveu já, "a organização de um modelo pluralista convoca a necessidade de uma articulação entre constituição, legislador e tribunais, cabendo à primeira a fixação das «regras secundárias» do pluralismo, ao legislador a concretização, num «espaço de jogo» constitucionalmente enquadrado que corresponde ao exercício da função legislativa, e ao juiz o controlo das opções do legislador por referência a parâmetros constitucionais" "117. Sobretudo em domínios de "divergência razoável" na sociedade aberta e plural, será de reconhecer ao legislador um necessário espaço de gestão da diversidade na comunidade plural, cabendo aos tribunais determinar os limites

112 Aharon BaraK, Proportionality, p. 751.

113 Aharon BaraK, Proportionality, p. 751.

114 Aharon BARAK, Proportionality, p. 751.

115 Vd. José LAmego, Elementos de metodologia jurídica, Coimbra, Almedina, 2016, pp. 274-275.

116 Sobre a questão, $v d$. JEREMY WALDRON, The Core of the Case Against Judicial Review, Yale Law Journal, 2006, pp. 115 ss. Disponível em: https://digitalcommons.law.yale.edu/ylj/vol115/iss6/3. E ainda, em diálogo com WALDRON, sobre desacordo sobre direitos fundamentais e justiça constitucional, JORGE ReIs NovaIs, Direitos Fundamentais e Justiça Constitucional em Estado de Direito Democrático, Coimbra, Coimbra Editora, 2012, pp. 149 ss.

117 Anabela CoSta Leão, Constituição e interculturalidade, p. 326. 
da controlabilidade judicial ${ }^{118}$, tendo por pano de fundo o princípio da separação e interdependência de poderes ${ }^{119}$.

Do ponto de vista da separação e interdependência de poderes, e tendo presente a crítica ao "ativismo" judicial já mencionada, tudo está em estabelecer a fonteira entre o que cabe ao legislador e o que que cabe aos órgãos de controlo ${ }^{120}$ ou, na terminologia de BARAK, a "zona de proporcionalidade" 121.

De resto, as críticas ao balanceamento judicial não têm necessariamente de se reconduzir à sua alegada ilegitimidade democrática, podem resultar também do carácter problemático, que já aqui se explorou, das operações de balanceamento em si, sejam ou não conduzidas pelo juiz.

\section{Que balanço?}

A proporcionalidade é um princípio em expansão, reclamando o estatuto de princípio global ou universal. Algumas dimensões

118 Segue-se aqui, de perto, a formulação adotada pelo Tribunal Constitucional no Acórdão n. ${ }^{\circ}$ 121/2010. Aí se afirmou, seguindo o Acórdão n. ${ }^{\circ}$ 105/90 do Tribunal Constitucional, que, "quando na comunidade jurídica tenham curso perspetivas diferenciadas e pontos de vista díspares e não coincidentes sobre as decorrências ou implicações que dum princípio "aberto" da Constituição devem retirar-se para determinado domínio ou para a solução de determinado problema jurídico", id est, na situação em que haja de "reconhecer-se e admitir-se como legítimo, na comunidade jurídica, um "pluralismo" mundividencial ou de concepções - sem dúvida cumprirá ao legislador (ao legislador democrático) optar e decidir" (\$26).

119 AnABela CoSTA LEÃO, Constituição e interculturalidade,p. 326.

120 Segundo Aharon Barak, Proportionality, p. 751, o objetivo do controlo judicial não é que o juiz apresente uma nova estrutura legislativa conforme à constituição, mas "determinar a constitucionalidade da estrutura apresentada pelo legislador", não cabendo ao juiz "estabelecer prioridades nacionais", mas controlar se as medidas adotadas pelo legislador segundo as prioridades que estabeleceu são proporcionais.

121 Segundo Aharon BARAK, Proportionality, p. 748, a "zona de proporcionalidade" é o domínio do legislador, no qual ele exerce discricionariedade quanto à necessidade de legislação, fins, meios e as limitações que terão de ser impostas a direitos fundamentais; manter as fronteiras da "zona de proporcionalidade" é a tarefa do juiz. 
da sua aplicação e justificação permanecem, porém, controvertidas. Neste texto, identificamos algumas críticas ao princípio da proporcionalidade, dirigidas sobretudo a uma das suas fases, a do balanceamento ou proporcionalidade em sentido estrito. Em síntese, alega-se que o recurso à proporcionalidade fragiliza os direitos e obscurece as suas dimensões morais, que o balanceamento é impreciso e pouco rigoroso, desde logo por causa da incomensurabilidade dos valores que se pretendem contrapesar, e que o controlo judicial da proporcionalidade das medidas legislativas é problemático do ponto de vista da democracia e da separação de poderes. Em resposta, sustenta-se que a proporcionalidade está aberta a dimensões morais, não fragiliza os direitos, antes pode reforçar a sua proteção através de exigências de fundamentação acrescida, que, desde que devidamente compreendido, o balanceamento não é perigoso nem subjetivo ou impreciso, ainda que seja complexo, e que o controlo judicial da proporcionalidade está, não só democraticamente legitimado, como não fere, em abstrato, a separação de poderes. Em jeito de balanço, parece ser de concluir, como propõe BARAK, que as vantagens excedem as críticas $^{122}$, e que o princípio da proporcionalidade tem um importante papel a desempenhar ao serviço da justificação e racionalização do controlo das afetações de direitos fundamentais.

Não pode confundir-se o princípio da proporcionalidade, ou mesmo o balanceamento, com o mau uso que dele possa ser feito, designadamente utilizando-o como mecanismo que permite exceder os limites do controlo de constitucionalidade ou alimentar o ativismo judicial ${ }^{123}$, ou decidir questões de direitos de forma não suficientemente fundamentada. Outros instrumentos, de resto, poderão permitir essa utilização ilegítima, não menos do que o princípio da proporcionalidade ${ }^{124}$. Tal não significa que não subsistam "proble-

122 Aharon Barak, Proportionality, p. 450 e, também, Matthias KlatT / MORITZ MEISTER, Proportionality, p. 708.

${ }^{123}$ Discutindo os riscos do "balanceamento judicial" e do ativismo dos tribunais, vd. BeRnHARD SCHLINK, Proportionality, p. 736.

124 Assim, segundo Niels Petersen, com base num estudo empírico de decisões do BVerfG, do Tribunal Constitucional da África do Sul e do Supremo Tribunal 
mas estruturais", carecidos de reflexão, relativos à forma como deve ser realizada a análise de proporcionalidade, ao papel e estrutura do balanceamento, ou à determinação dos critérios através dos quais este deve operar ${ }^{125}$.

A "abertura metodológica" do princípio da proporcionalidade pode ser vista como uma força, ao invés de uma fraqueza. Como escreve SCHLINK, a sua abertura torna a proporcionalidade a arena na qual diferentes entendimentos da relação entre cidadão e Estado e entre tribunal e legislador podem confrontar-se ${ }^{126}$. Mas, e tendo especialmente em vista a questão da dimensão de moralidade política vista e debatida supra, torna também o princípio aberto à diversidade e ao pluralismo, e apto para a sua universalização, na medida que se revela inclusivo a uma pluralidade de razões ${ }^{127}$.

Finalmente, a compreensão atual e futura do princípio não pode esquecer precisamente a sua universalização nem o seu possível "efeito estandardizador" das culturas constitucionais ${ }^{128}$. Não obstante a sua vocação transcultural, enquanto resposta universal a problemas universais, a expansão do princípio da proporcionalidade não está

do Canadá, não se pode concluir que o recurso ao "balancing" sirva para reforçar o ativismo. $\mathrm{O}$ estudo mostra que os tribunais não usam o "balancing "para promover o seu ativismo, antes se autolimitam e usam a proporcionalidade como instrumento de controlo de racionalidade ("instrument of rationality review"). Mostra ainda que outros mecanismos à partida mais inofensivos podem também ser utilizados para reforçar os poderes de intervenção dos tribunais. NIELS PETERSEN, Do Constitutional Courts Use Balancing to Promote Judicial Activism? 2015, Latest Thinking, LT Video Publication DOI: https://doi.org/10.21036/ LTPUB10012 Trata-se de um resumo de NIELS PETERSEN, Verhältnismäßigkeit als Rationalitätskontrolle. Eine Rechtsempirische Studie Verfassungsrechtlicher Rechtsprechung zu den Freiheitsgrundrechten, Tübingen, Mohr Siebeck,2015.

${ }^{125}$ Bernhard SCHLink, Proportionality, pp. 727-728.

${ }^{126}$ Bernhard SCHLinK, Proportionality, pp. 730-731.

${ }^{127}$ Sobre a questão, SuZANA TAVARES DA SILVA, O tetralemma, p. 649.

${ }^{128}$ Como escreve Bernhard SCHLINK, Proportionality, p.736, a aplicação do princípio da proporcionalidade teve e continuará a ter um efeito estandardizador nas diferentes culturas constitucionais ou, de outra perspetiva, antes é um standard que as diferentes culturas constitucionais partilham, fazendo parte de uma gramática constitucional que é a base de todas as linguagens e culturas constitucionais, e do qual estas se tornam progressivamente mais conscientes. 
isenta de riscos e desafios ${ }^{129}$, desde logo os que resultam da diversidade de sistemas jurídicos e da articulação com as suas identidades específicas ${ }^{130}$.

${ }^{129}$ Para os quais adverte SuZANA TAVARES DA SiLVA, O tetralemma, pp. 640 ss.

130 Suzana Tavares da Silva, O tetralemma, pp. 640 ss. Em especial, Moshe COHEN-ELYIA / IDDO PORAT, Is Proportionality Culturally Based?, advertem para as dimensões de oportunidade e risco e para o impacto sobre as doutrinas jurídicas locais: "The universal and generic nature of proportionality holds both promise and risk. There is the promise of coherence and simplicity and of the benefits of participating in a global dialogue and global project. But, in Einstein's words, "everything should be made as simple as possible, but not simpler." (...) a risk posed by proportionality when it is incorporated into new legal systems that, as a result, local doctrines will lose their nuance and richness and become less adapted to their own environment. To use a zoological analogy, proportionality can be compared to the universally adaptable bird that migrates and pushes out local species wherever it lands. In this case, too, functionality and adaptability come at a cost in terms of the richness of the local environment". 


